\title{
HIDROVIA TOCANTINS-ARAGUAIA: IMPORTÂNCIA E IMPACTOS ECONÔMICOS, SOCIAIS E AMBIENTAIS SEGUNDO A PERCEPÇÃO DOS AGENTES ECONÔMICOS LOCAIS
}

\author{
Alivinio de Almeida
}

Tese apresentada à Escola Superior de Agricultura "Luiz de Queiroz", Universidade de São Paulo, para obtenção do título de Doutor em Ciências, Área de Concentração: Economia Aplicada.

PIR A CIC A B A

Estado de São Paulo - Brasil

Agosto - 2004 


\title{
HIDROVIA TOCANTINS-ARAGUAIA: IMPORTÂNCIA E IMPACTOS ECONÔMICOS, SOCIAIS E AMBIENTAIS SEGUNDO A PERCEPÇÃO DOS AGENTES ECONÔMICOS LOCAIS
}

\author{
ALiVinio de Almeida \\ Engenheiro Agrônomo
}

Orientador: Prof. Dr. FERNANDO CURI PERES

Tese apresentada à Escola Superior de Agricultura "Luiz de Queiroz", Universidade de São Paulo, para obtenção do título de Doutor em Ciências, Área de Concentração: Economia Aplicada.

PIR A CIC A B A

Estado de São Paulo - Brasil

Agosto - 2004 
Dados Internacionais de Catalogação na Publicação (CIP)
DIVISÃO DE BIBLIOTECA E DOCUMENTAÇÃO - ESALQ/USP

Almeida, Alivinio de

Hidrovia Tocantins-Araguaia: importância e impactos econômicos, sociais e ambientais segundo a percepção dos agentes econômicos locais / Alivinio de Almeida. - - Piracicaba, 2004.

155 p. : il.

Tese (doutorado) - - Escola Superior de Agricultura Luiz de Queiroz, 2004.

Bibliografia.

1. Desenvolvimento econômico 2. Hidrovias 3. Impactos ambientais 4. Impactos econômicos 5. Impactos sociais I. Título

CDD 551.483

"Permitida a cópia total ou parcial deste documento, desde que citada a fonte - $\mathrm{O}$ autor" 
À minha filha Estela que, na inocência de sua pouca idade, sofreu a ausência, irrecuperável, de um pai que tanto a ama.

À minha Família que, ao longo deste caminho, me deu apoio e amor incondicionais.

DEDICO. 


\section{AGRADECIMENTOS}

Um trabalho desta envergadura não pode ser fruto do esforço de uma única pessoa. Ele envolve, naturalmente, muitas, talvez inúmeras colaborações institucionais e pessoais recebidas direta e indiretamente ao longo de todo o caminho. Esta tese, especialmente, representa um trabalho feito graças ao apoio de amigos de 20 anos a quem eu muito devo agradecer. Diante disso, esta página se cobre de uma imensa responsabilidade que pretendo cumprir, a partir de agora.

À sociedade brasileira, através dos governos federal e estadual, agradeço pelo financiamento público em todas as etapas de minha formação, do ensino fundamental ao doutorado. Especialmente no doutorado, agradeço ao Conselho Nacional de Desenvolvimento Científico e Tecnológico - CNPq, pelo financiamento direto através da bolsa de estudo. Espero, como professor do ensino superior público, fazer jus a esse investimento.

Às duas universidades, Universidade do Tocantins - UNITINS e Fundação Universidade Federal do Tocantins - UFT, que me apoiaram financeira e institucionalmente durante o estudo, agradeço. Nelas, estendo meus agradecimentos à Congregação do Curso de Ciências Econômicas, especialmente aos colegas professores, cujo cavalheirismo me permitiu continuar em Piracicaba. 
À Universidade de São Paulo que, novamente, me acolheu em sua Escola Superior de Agricultura Luiz de Queiroz - ESALQ, mais precisamente no Departamento de Economia, Administração e Sociologia, faço um agradecimento pelos últimos 20 anos de parceria. Estes agradecimentos se estendem ao Conselho de Pós-Graduação, nas pessoas do Professor Dr. Ricardo Shirota e da Maielli, estimada Secretária.

Ao Professor Dr. Fernando Curi Peres agradeço pela orientação precisa, pela disposição em aceitar desafios e pela dedicação a este trabalho. Sem isso, eu teria feito água na Hidrovia que estudei.

Ao Pesquisador Dr. Luís Alberto Ambrósio, do Instituto Agronômico de Campinas, à Professora Dra Elaine Mendonça Bernardes, da Universidade Estadual Paulista, ao Professor Dr. Evaristo Marzabal Neves e ao Professor Dr. Alexandre Lahóz Mendonça de Barros, agradeço pela colaboração no desenvolvimento do trabalho e pela avaliação dos resultados do estudo.

Ao Professor Dr. José Vicente Caixeta Filho, agradeço por contribuir para a elaboração do estudo, enquanto lhe foi possível.

À Dilza Medeiros que, durante o tempo deste trabalho, dedicou apoio e compreensão totais, agradeço. Pelo zelo comigo e com nossa filha, durante este longo período em que estive longe, sempre lhe serei grato.

Aos amigos do Departamento de Economia, Administração e Sociologia, que desde a graduação, sempre me dedicaram tratamento especial, agradeço. Correndo o risco de esquecer alguém por falha de memória, cito: Elenice, Márcia, Helena, Cristiane, Luciane, Angélica, Cida e Pedro. Mais recentemente, Ligiana e Álvaro entraram na lista. Esse agradecimento alcança, também, os amigos Professor Dr. Paulo Fernando Cidade de Araújo e a Secretária Acadêmica da ESALQ, Sra. Márcia Silveira. 
Aos colegas de curso, cuja solidariedade foi fundamental neste caminho solitário, faço o agradecimento através da minha querida amiga, Maria Piedade de Araújo, que esteve sempre "extremamente" presente.

À Tânia Rodrigues, pelo apoio, compreensão e presença na consolidação do trabalho, agradeço sinceramente.

Aos amigos do Tocantins que me apoiaram na realização deste doutorado, desde o primeiro instante, agradeço. Ao Jamil, João, Bianchi e Silvana, faço meu agradecimento pelo apoio efetivo na realização deste curso. À Kátia Maia, em especial, agradeço por compartilhar, enquanto foi possível, deste meu desafio pessoal.

À todos que direta ou indiretamente se sentem parceiros nesta realização, deixo meu agradecimento. 


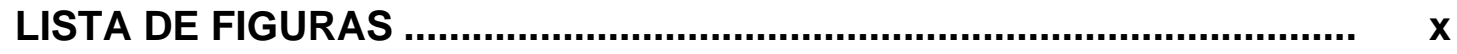

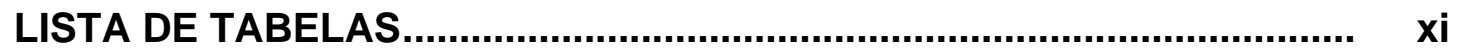

LISTA DE QUADROS ....................................................................... xiii

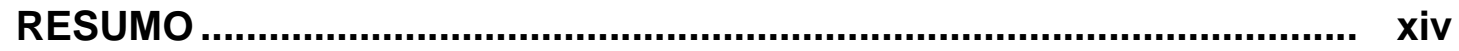

SUMMARY ................................................................................... Xvii

$1 \quad$ INTRODUÇÃO .............................................................................. 1

$1.1 \quad$ Problema e justificativa ....................................................... 3

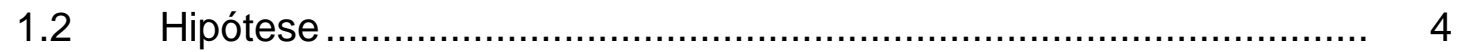

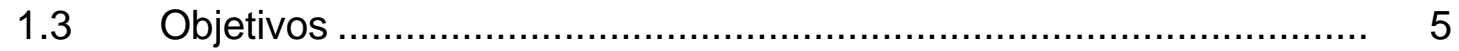

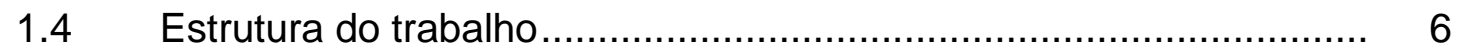

2 CONTRIBUIÇÃO DA INFRA-ESTRUTURA PÚBLICA DE TRANSPORTE AO CRESCIMENTO E DESENVOLVIMENTO ECONÔMICOS ............................................................................... 7

2.1 Crescimento e desenvolvimento econômicos …............................ 7

2.2 Definição de infra-estrutura pública de transporte......................... 10

2.3 Infra-estrutura de transporte no processo econômico .................... 13

3 AVALIAÇÃO DE PROJETOS DE INFRA-ESTRUTURA DE TRANSPORTE

3.1 Importância da avaliação econômica de projetos de infraestrutura

3.2 Métodos de avaliação econômica de projetos de infra-estrutura ..... 23 
3.3 Avaliação econômica de projetos de infra-estrutura de transporte ... 27

$4 \quad$ SISTEMA DE TRANSPORTE NO ESTADO DO TOCANTINS ........ 35

$4.1 \quad$ Tocantins: aspectos históricos e econômicos ............................. 35

4.2 O sistema de transportes no Tocantins ..................................... 37

4.3 Hidrovia Tocantins-Araguaia: identificação e caracterização ........... 44

4.3.1 Características físicas e técnicas .............................................. 47

4.3.2 Características econômicas ................................................. 51

4.3.3 Impactos ambientais e socio-econômicos................................... 65

4.3.4 Viabilidade econômica ........................................................ 75

5 IMPORTÂNCIA E IMPACTOS DA HIDROVIA TOCANTINSARAGUAIA: MATERIAL E MÉTODOS DE PESQUISA ................ 79

$5.1 \quad$ Variáveis de interesse ao estudo ........................................... 80

5.2 Método de coleta de dados e de informações............................. 81

5.2.1 Entrevistas individuais ......................................................... 82

5.2.1.1 Amostra de entrevistados.................................................. 84

5.2.1.2 Modelo estatístico para análise dos dados ................................. 88

5.2.1.3 Método de regressão stepwise .......................................... 90

5.2.2 Grupo focal................................................................ 93

$6 \quad$ RESULTADOS E DISCUSSÃO ............................................... 103

6.1 Entrevistas individuais: primeiras evidências de campo............... 103

6.1.1 Considerações sobre o levantamento de dados ......................... 104

6.1.2 Considerações sobre o tamanho da amostra............................... 109

6.1.3 Considerações sobre os entrevistados ................................... 113

6.1.4 Impressões sobre a prestação de serviços ao município................ 115

6.1.5 Impressões sobre os impactos no município ............................. 119

6.1.6 Impressões sobre a importância para o município ........................ 123

6.1.7 Inserção nos projetos locais .................................................. 125

6.1.8 Considerações sobre as informações ...................................... 127 
6.2 Entrevistas individuais: resultados da análise econométrica.......... 127

6.2.1 Procedimentos básicos .................................................... 128

6.2.2 Caracterização dos dados.................................................. 130

6.2.3 Resultados da regressão stepwise......................................... 133

6.2.4 Considerações sobre os resultados econométricos ...................... 135

6.3 Grupo focal: aspectos da participação .................................... 136

6.3.1 Considerações do grupo sobre a HTA .................................. 137

$7 \quad$ CONCLUSÕES E SUGESTÕES ............................................... 140

REFERÊNCIAS BIBLIOGRÁFICAS .................................................. 144

APÊNDICE ............................................................................... 151 


\section{LISTA DE FIGURAS}

Página

1 Rede intermodal de transporte existente e planejada, Estado do Tocantins, Brasil, 1999. 39

$2 \quad$ Traçado da rodovia BR 153, Brasil, 2003....................................... 40

3 Traçado projetado para a Ferrovia Norte-Sul, Brasil, 1999. ............... 43

$4 \quad$ Bacia do Tocantins-Araguaia, Brasil.............................................. 48

5 Opções econômicas na exploração da Bacia Tocantins-Araguaia, Brasil.

6 Plataforma multimodal de Aguiarnópolis, Estado do Tocantins.

7 Setores e atividades que podem ser influenciados pela presença da Hidrovia Tocantins-Araguaia, Brasil.

8 Municípios visitados no levantamento de campo, Hidrovia TocantinsAraguaia, fev-mar de 2004, Estado do Tocantins.

9 Porto para embarque de carga, rio Araguaia, Município de Xambioá (TO), fev/2004.

10 Galpão de equipamentos para transbordo de carga a granel, rio Araguaia, Município de Xambioá (TO), fev/2004.

11 Chatas graneleiras e tanque-combustível atracadas no rio Araguaia, Município de Couto Magalhães (TO), fev/2004.

12 Perfil de distribuição dos dados levantados sobre a Hidrovia Tocantins-Araguaia, segundo a variável selecionada. 


\section{LISTA DE TABELAS}

Página

1 Distribuição da malha viária do Estado do Tocantins, segundo a esfera administrativa responsável, em quilômetros, 1999.

2 Previsão de inversão de recursos na implantação da Hidrovia Tocantins-Araguaia, segundo o tipo de investimento.

3 Movimentação geral de cargas nas principais hidrovias, Brasil, 19982000 (em toneladas)

4 Movimentação de cargas, Hidrovia Tocantins-Araguaia, Brasil, 19982000

5 Características demográficas, sociais e econômicas dos principais municípios na área de influência da Hidrovia Tocantins-Araguaia, Estado de Goiás, Brasil, 2000.

6 Características demográficas, sociais e econômicas dos principais municípios na área de influência da Hidrovia Tocantins-Araguaia, Estado do Mato Grosso, Brasil, 2000.

7 Características demográficas, sociais e econômicas dos principais municípios na área de influência da Hidrovia Tocantins-Araguaia, Rio Araguaia, Estado do Tocantins, Brasil, 2000.

8 Características demográficas, sociais e econômicas dos principais municípios na área de influência da Hidrovia Tocantins-Araguaia, Rio Tocantins, Estado do Tocantins, Brasil, 2000

9 Características demográficas, sociais e econômicas dos principais municípios na área de influência da Hidrovia Tocantins-Araguaia, Estado do Pará, Brasil, 2000. 
10 Características demográficas, sociais e econômicas dos principais municípios na área de influência da Hidrovia Tocantins-Araguaia, Estado do Maranhão, Brasil, 2000.

11 Impactos ambientais sobre o meio físico, associados à implantação, operação e manutenção da Hidrovia Tocantins-Araguaia, Brasil.

12 Impactos ambientais sobre o meio biótico (fauna), associados à implantação, operação e manutenção da Hidrovia TocantinsAraguaia, Brasil.

13 Impactos ambientais sobre o meio antrópico, associados à implantação, operação e manutenção da Hidrovia TocantinsAraguaia, Brasil.

14 Características demográficas, sociais e econômicas dos principais municípios na área de influência da Hidrovia Tocantins-Araguaia, Estado do Tocantins, Brasil, 2000.

15 Identificação da amostra de entrevistados sobre a Hidrovia TocantinsAraguaia nos diferentes municípios tocantinenses onde atuam

16 Considerações sobre os serviços prestados pela Hidrovia TocantinsAraguaia

17 Expectativas dos entrevistados sobre os possíveis impactos da Hidrovia Tocantins-Araguaia sobre os municípios tocantinenses onde atuam

18 Expectativas dos entrevistados sobre os possíveis impactos das Hidrovias Araguaia e Tocantins sobre os municípios tocantinenses onde atuam.

19 Considerações dos entrevistados sobre a importância da Hidrovia Tocantins- Araguaia para o município tocantinense onde atuam .....

20 Projetos públicos ou privados que incorporam a Hidrovia TocantinsAraguaia declarados pelos entrevistados, segundo o município de implantação 


\section{LISTA DE QUADROS}

Página

1 Benefícios incidentes em um projeto de investimento em estradas, Japão, 1999.

2 Matriz genérica de Estrutura Lógica.

3 Agentes econômicos interessantes à pesquisa, localizados nos municípios da área de influência da Hidrovia Tocantins-Araguaia, Brasil.

4 Variáveis consideradas no modelo estatístico sobre a importância da Hidrovia Tocantins-Araguaia para o município.

5 Resultados da análise econométrica do modelo estatístico sobre a Hidrovia Tocantins-Araguaia, segundo as variáveis selecionadas pelo método de regressão linear stepwise 


\title{
HIDROVIA TOCANTINS-ARAGUAIA: IMPORTÂNCIA E IMPACTOS ECONÔMICOS, SOCIAIS E AMBIENTAIS SEGUNDO A PERCEPÇÃO DOS AGENTES ECONÔMICOS LOCAIS
}

\author{
Autor: ALIVINIO ALMEIDA \\ Orientador: Prof. Dr. FERNANDO CURI PERES
}

\section{RESUMO}

O presente estudo avalia a percepção de potenciais usuários da Hidrovia Tocantins-Araguaia sobre seus possíveis impactos econômicos, sociais e ambientais em 7 municípios, no Estado do Tocantins. Foram entrevistados 24 indivíduos representantes do poder público, da iniciativa privada, de entidades de classe e de organizações não-governamentais ambientalistas. Como evidência de campo, verificou-se que, no rio Araguaia, a limitada infra-estrutura operacional, instalada em 1998, está completamente deteriorada e que as embarcações estão sem uso desde 2000. No rio Tocantins, verificou-se a inexistência de eclusas que permitam vencer os desníveis naturais mais agressivos, aumentando a navegabilidade e possibilitando o tráfego dos comboios. Diante disso, pode-se afirmar que a Hidrovia ainda está longe de se consolidar como um modal de transporte alternativo para o Estado. Quanto à opinião dos entrevistados, de modo geral, consideram interessante, oportuna e estratégica a presença da Hidrovia Tocantins-Araguaia em seus municípios, principalmente para o transporte de 
insumos e produtos. A despeito da pouca informação de que dispunham sobre sua dimensão, potencial e impactos, manifestaram expectativas positivas quanto aos aspectos econômicos e sociais e negativas quanto aos ambientais. Vários assinalaram que o lento processo de implantação compromete sua inserção nos projetos institucionais ou empresariais e causa descrença sobre sua consolidação. A análise estatística dos dados de campo, realizada através de uma regressão do tipo stepwise, revela que os agentes econômicos relacionam a importância da Hidrovia Tocantins-Araguaia para seus municípios aos impactos econômicos, sociais e ambientais que ela possa causar. Os resultados individuais mostraram-se significativos, segundo o nível de probabilidade " $p$ ", para as variáveis selecionadas pelo modelo, sob $\alpha=0,20$ (erro tipo I) estabelecido à priori. Foram significativos e positivos os coeficientes das variáveis geração de emprego e renda, oferta de serviços estruturais municipais e valor das propriedades ribeirinhas e, negativos, os coeficientes das variáveis conhecimento e informação sobre a hidrovia, atividades de indústria e comércio, atividades de turismo e oferta de serviços sociais municipais. A variável atividades de agricultura não foi significativa. O grupo focal, realizado com a finalidade de ampliar a discussão qualitativa sobre a Hidrovia TocantinsAraguaia, foi consensual em relação aos benefícios econômicos e sociais proporcionados ao Estado do Tocantins e aos circunvizinhos. Porém, alertou sobre os possíveis impactos negativos no meio ambiente, especialmente no Rio Araguaia. Em linhas gerais, o estudo permitiu concluir pela necessidade e benefícios de serem consideradas as impressões qualitativas dos potenciais usuários na avaliação de viabilidade econômica de projetos de infra-estrutura de transporte. Tais impressões serviriam como parâmetros de ponderação dos aspectos quantitativos levantados pelo empreendedor, favorecendo a escolha do empreendimento mais adequado sob o ponto de vista econômico, social e ambiental. Sobre a implantação efetiva da Hidrovia Tocantins-Araguaia, no Estado do Tocantins, alerta-se para os impactos que ela possa causar. Ainda que sob o ponto de vista comum sejam esperados benefícios econômicos e 
sociais, sob o ponto de vista ambiental a sensação é de perda de qualidade. O Rio Araguaia, pela sua juventude e fragilidade dos ecossistemas que congrega, exige tratamento especial, baseado num cuidadoso plano de intervenções, que respeite suas características naturais, bem como as das espécies e populações que o habitam, inclusive a humana. O Rio Tocantins, ainda que menos indefeso pela sua maior idade, precisa de tratamento adequado, uma vez que dele depende não só a Hidrovia Tocantins e o projeto multimodal de transporte mas, também, todo o projeto de geração de energia hidrelétrica do Estado. 


\title{
TOCANTINS-ARAGUAIA WATERWAY: IMPORTANCE AND ECONOMIC, SOCIAL AND ENVIRONMENTAL IMPACTS, ACCORDING TO THE PERCEPTION OF THE LOCAL ECONOMIC AGENTS
}

\author{
Author: ALIVINIO ALMEIDA \\ Adviser: Prof. Dr. FERNANDO CURI PERES
}

\section{SUMMARY}

The present study aims to evaluate the perception of potential users of the Tocantins-Araguaia Waterway concerning the possibility of economic, social and environmental impacts in 7 municipalities, in the State of Tocantins. For this purpose, 24 individuals representing the government, private sector and non-government environmental organizations, have been interviewed. Field evidences shows that in the Araguaia River the limited operational infrastructure, installed in 1998, is completely deteriorated and that the ships have not been used since the year 2000. It has been, in the Tocantins River, noticed the nonexistence of dams, which allow to regulate the more aggressive natural differences in the river levels, increasing the navigability of the convoys. Therefore, it can be stated that the waterway is still far from it's consolidation as a transportation alternative for this State. As for the opinion of those who have been interviewed, in general, the presence of the Tocantins- Araguaia Waterway in their municipalities is considered interesting and strategic, mainly for the transportation of inputs and finished goods. Despite the little information 
available as to its dimension, potential and impacts, positive expectation have been manifested as to economic and social aspects, and negative as to environmental aspects. Several of them stated that the slow process of implantation difficult its introduction in the projects or enterprises and causes the incredibility over its consolidation. The statistical analysis of the field data, made through a stepwise regression reveals that the economic agents relates the importance of the Tocantins-Araguaia Waterway for their municipalities to the economic, social and environmental impacts that it might cause. The individual results are significant, according to the confidence level $p$, for the variables selected by the model, under $\alpha=0,20$ (tipe I error) à priori determined. The coefficients of the variables job creation and income improvement, municipal social service offer and the value of the water side properties were significant and positive and the coefficients of the variables knowledge and information on waterway, commercial and industrial activities, tourism activities, and the municipal social service offer, were negative. The variable agricultural activities was not significant. The focal group about Tocantins-Araguaia Waterway was consensual over the economic and social benefits for the State of Tocantins. However, the group warned about possible negative impacts in the environment, especially in the Araguaia River. In general, the study permitted to conclude for the necessity and benefits to consider the qualitative impressions of the potential users in the evaluation of the economic viability of transportation infrastructure projects. Such impressions would serve as parameters of the qualitative aspects brought forward by the entrepreneur, improving the choice of the most adequate enterprise under the economic, social and environmental aspects. As for the effective implantation of the Tocantins-Araguaia Waterway, in the State of Tocantins, the impacts that it may cause should be brought forward. Although economic and social benefits are expected, the perception is of loss of the environmental quality. The Araguaia River, because of its youth and ecosystems fragility, demands a special treatment, based on a careful plan of interventions, that respects its natural characteristics, as well as the species and populations 
that inhabit it, including the human. The Tocantins River also needs a proper treatment due to the Tocantins Waterway, the multimodal transportation and the hydroelectric generation projects of the State, which depends on it. 


\section{INTRODUÇÃO}

Definida em função dos serviços que presta à sociedade, a infraestrutura de transporte facilita a realização da atividade produtiva e social de indivíduos e empresas. Ao propiciar condições para o crescimento econômico, essa infra-estrutura torna-se essencial ao desenvolvimento, ainda que não seja suficiente para induzir sua ocorrência.

A natureza pública dos serviços de transporte e o elevado volume de investimentos necessário à implantação da infra-estrutura fazem com que a oferta inicial seja feita, em geral, pelo poder público. Os serviços, inicialmente, são livres de taxas e encargos ou, então, funcionam sob taxas publicamente reguladas. Em momento posterior, estimula-se a participação privada na manutenção, administração e ampliação da infra-estrutura de transporte. Nesse estágio, a ação governamental se direciona para a regulamentação e controle da prestação dos serviços, buscando evitar o uso do poder de monopólio que a própria natureza dos serviços oferece.

O estabelecimento dos papéis dos setores público e privado, entretanto, não resolve a questão mais relevante, qual seja, determinar a prioridade de implantação da infra-estrutura de transporte necessária e suficiente para o crescimento e desenvolvimento econômicos da sociedade. A maior dificuldade do processo está na identificação e mensuração dos impactos qualitativos e quantitativos de natureza econômica, social e ambiental provocados pela infra-estrutura. Essa avaliação é desafiadora por ser não consensual. Porém, é fundamental à tomada de decisão, não devendo ser 
evitada, dada a limitação dos recursos financeiros públicos e privados para esse tipo de investimento. Outro aspecto relevante é que o prazo de maturação e retorno dos investimentos em infra-estrutura de transporte é, geralmente, longo, o que aumenta a relevância da análise qualitativa e quantitativa dos projetos de modo a captar os ônus e bônus econômicos e sociais da inversão de recursos materiais, humanos e financeiros na implantação da infra-estrutura desejada.

Diante da necessidade de refinamento do processo de avaliação dos impactos relacionados aos projetos de infra-estrutura de transporte, o presente estudo procura identificar os diferentes métodos utilizados, evidenciando as considerações disponíveis na literatura. De modo geral, o que se observa é o uso universal da análise benefício-custo, a despeito das críticas sobre sua abordagem essencialmente quantitativa e financeira. Tal aspecto estimula a busca de outros procedimentos que procurem captar questões qualitativas vinculadas à implantação e operação dos objetos dos projetos. Os procedimentos não têm por intenção substituir a análise benefício-custo mas, sim, complementá-la, de modo que seus resultados reflitam as diferentes naturezas dos impactos provocados pela infra-estrutura.

O contexto de avaliação dos impactos de projetos de infra-estrutura, especialmente os de transporte, estabelece também a necessidade de se conhecer não somente a opinião dos idealizadores dos projetos, mas, também a dos possíveis usuários e/ou beneficiários. Esse contraponto tem por finalidade melhorar a sintonia entre projetista e usuário, promovendo a escolha de projetos interessantes a ambos e à sociedade como um todo. Assim é que, em linhas gerais, este estudo se detém, especialmente, na avaliação dos impactos econômicos, sociais e ambientais, quantitativos ou qualitativos, dos projetos de infra-estrutura de transporte, segundo a percepção dos usuários, por entender que se trata de aspecto fundamental à análise e que tem encontrado 
dificuldades teóricas e práticas para a sua consecução. Especificamente, procura-se realizar essa tarefa considerando o projeto de implantação e operação da Hidrovia Tocantins-Araguaia nos principais municípios lindeiros aos rios Araguaia e Tocantins, no Estado do Tocantins. Neles, busca-se captar a percepção dos usuários sobre a importância dessa hidrovia diante dos impactos econômicos, sociais e ambientais que ela possa causar aos municípios onde residem e/ou atuam.

\subsection{Problema e justificativa}

A decisão sobre a implantação de projetos de infra-estrutura de transporte considera, basicamente, aspectos quantitativos e financeiros geralmente identificados apenas sob o ponto de vista dos idealizadores dos projetos. Porém, é preciso considerar que esse tipo de infra-estrutura, geralmente de grandes dimensões, produz, igualmente, efeitos de natureza qualitativa sobre as regiões onde se instala. Além disso, é necessário reconhecer que a importância da infra-estrutura é representada pelo bem-estar que proporciona aos possíveis usuários e, por isso, é fundamental que o projeto considere suas impressões sobre os impactos econômicos, sociais e ambientais em seus municípios. Essa consideração possibilita a elaboração e o desenvolvimento de projetos de infra-estrutura mais equilibrados em termos quantitativos e qualitativos e mais adequados aos interesses de idealizadores e de usuários.

Outro aspecto importante relacionado ao procedimento de captação das expectativas dos usuários sobre os impactos da infra-estrutura de transporte é que ele favorece a definição de medidas mitigadoras ou compensatórias dos impactos negativos que a infra-estrutura possa causar aos municípios e à população da sua área de influência. Da mesma forma, permite 
estabelecer estratégias que potencializem os impactos positivos do projeto, elevando o nível de bem-estar proporcionado pela infra-estrutura.

Diante dos argumentos favoráveis ao conhecimento das expectativas dos possíveis usuários sobre os diferentes impactos das infra-estruturas de transporte, justifica-se o esforço de pesquisa na captação e análise de suas impressões, considerando os municípios em que atuam e/ou residem. Seguindo essa linha de raciocínio é que o presente estudo propõe conhecer as expectativas dos possíveis usuários, aqui entendidos como agentes econômicos públicos ou privados, sobre a importância e impactos econômicos, sociais e ambientais da Hidrovia Tocantins-Araguaia, no Estado do Tocantins. Vale observar que a hidrovia ainda está numa fase muito inicial de sua implantação, o que a coloca, aos olhos dos usuários, como um projeto a ser desenvolvido. Assim, é a partir dela que se irradia a presente pesquisa, tomando por base a hipótese apresentada a seguir.

\subsection{Hipótese}

Os agentes econômicos dos principais municípios tocantinenses lindeiros aos rios Araguaia e Tocantins consideram importante a presença ${ }^{1}$ da Hidrovia Tocantins-Araguaia para seus municípios como infra-estrutura prestadora de serviços de transporte e têm expectativas sobre a ocorrência, o sentido e a intensidade dos impactos econômicos, sociais e ambientais causados por ela, a despeito de sua atual inexistência física e operacional, o que os leva a não considerá-la em seus projetos institucionais.

\footnotetext{
${ }^{1}$ A presença pode ser definida pelo estágio de implantação e/ou de operação, proximidade e acessibilidade física, operacional, econômica e social da Hidrovia Tocantins-Araguaia em relação ao Município onde o agente econômico atua ou se localiza.
} 


\subsection{Objetivos}

\section{Geral:}

Conhecer e analisar as impressões dos agentes econômicos públicos, privados e não-governamentais, atuantes nos principais municípios lindeiros aos rios Araguaia e Tocantins, sobre a importância e impactos econômicos, sociais e ambientais da Hidrovia Tocantins-Araguaia em seus municípios.

\section{Específicos:}

a) estabelecer, através de referências literárias, a relação entre o investimento público em infra-estrutura de transporte e o desenvolvimento econômico regional;

b) discutir o processo de avaliação e seleção de investimentos em infraestrutura de transporte, com ênfase na consideração dos impactos qualitativos dos projetos e na relevância da opinião dos usuários;

c) caracterizar a infra-estrutura de transporte que compõe o sistema de transporte do Estado do Tocantins, realçando a Hidrovia TocantinsAraguaia;

d) analisar as impressões dos agentes econômicos públicos, privados e nãogovernamentais sobre a importância da presença da Hidrovia TocantinsAraguaia, considerando os impactos na economia, sociedade e meio ambiente, captadas nos principais municípios tocantinenses lindeiros aos rios Araguaia e Tocantins; e, 
e) discutir a possibilidade de influência e a validade da utilização dos resultados obtidos no processo de implantação e operação da Hidrovia Tocantins-Araguaia.

\subsection{Estrutura do trabalho}

O Capítulo 1 apresenta o problema, a justificativa, o objetivo geral e os específicos, bem como traz a hipótese sobre a qual o estudo se orienta.

O Capítulo 2 traz uma revisão da literatura recente sobre a importância dos investimentos em infra-estrutura, especialmente a de transporte, nos processos de crescimento e desenvolvimento econômicos.

O Capítulo 3 reúne a discussão sobre os métodos de avaliação dos impactos de projetos de infra-estrutura utilizados em diferentes lugares do mundo.

O Capítulo 4 apresenta a caracterização do Estado do Tocantins e de seu sistema de transporte implantado e planejado.

O Capítulo 5 apresenta o método e o material utilizado para a realização do trabalho de campo, junto aos possíveis usuários da Hidrovia Tocantins-Araguaia. O método utilizado para a análise estatística das informações obtidas também é apresentado.

O Capítulo 6 traz a análise e discussão dos resultados da pesquisa, sob os contextos qualitativo e quantitativo.

O Capítulo 7 apresenta as conclusões e sugestões do estudo. 


\title{
2 CONTRIBUIÇÃO DA INFRA-ESTRUTURA PÚBLICA DE TRANSPORTE AO CRESCIMENTO E DESENVOLVIMENTO ECONÔMICOS
}

\begin{abstract}
A contribuição da infra-estrutura pública de transporte para o crescimento e desenvolvimento econômicos, promovendo aumento do produto da economia e das rendas individuais, bem como a melhoria da qualidade de vida da população tem sido, sempre, assinalada. Contudo, existem muitos questionamentos sobre o tipo e alcance dos impactos causados pela presença ou ausência desse tipo de infra-estrutura e, também, sobre quem deve ser o principal responsável pela sua implantação: o setor público ou o setor privado. Neste capítulo, os principais argumentos dessa discussão são identificados e analisados à luz da literatura disponível sobre o assunto.
\end{abstract}

\subsection{Crescimento e desenvolvimento econômicos}

A discussão sobre o papel e a importância da infra-estrutura pública de transporte para o crescimento e desenvolvimento econômicos fica enriquecida se, antes, as características e alguns aspectos desses processos econômicos forem assinalados.

Crescimento econômico, de modo geral, é definido na literatura como o aumento do produto global de uma economia, condicionado pela combinação, comportamento e contribuição dos diferentes fatores de produção utilizados. Nesse contexto, existem vários modelos de crescimento propostos que, segundo Simonsen \& Cysne (1989) estabelecem, tipicamente, que o produto 
real da economia ( $Y$ ) é função crescente do estoque de capital $(K)$, da força de trabalho $(N)$ e do tempo $(t)$ ou seja:

$$
Y=f(K, N, t)
$$

Os autores consideram que a função é crescente dado que capital e trabalho contribuem para a produção e que o tempo contribui com o progresso tecnológico cujo objetivo é melhorar a produtividade dos fatores disponíveis.

Dentre os modelos de crescimento econômicos mais tradicionais, Simonsen \& Cysne 1989) citam o de Harrod-Domar, o de Kaldor-Pasinetti e o de Solow. O primeiro considera que o crescimento do produto é limitado, exclusivamente, pelo estoque de capital, admitindo-se que haja excesso de mão-de-obra. O segundo admite a mesma função de produção de HarrodDomar mas supõe que a economia alcance o pleno emprego de ambos os recursos, capital e força de trabalho, limitando o crescimento do produto. $O$ terceiro, de inspiração neoclássica considera diferenciável a função de produção $Y=f(K, N, t)$ admitindo que os mercados funcionem em concorrência perfeita. Neste caso, supõe que a função seja homogênea do primeiro grau e, por isso, o produto se divide integralmente entre remuneração do capital e do trabalho. Simonsen \& Cysne (1989) alertam, porém, que esses modelos são muito pouco informativos como base para a formulação de uma política de crescimento, uma vez que não esclarecem, adequadamente, como acelerar a taxa de progresso tecnológico que, no longo prazo, seria igual à taxa de aumento da produtividade média do trabalho.

O capital considerado nos modelos de crescimento econômico distinguia-se em três tipos: capital físico, financeiro e natural. O capital financeiro, considerado muito importante nos modelos, diz respeito à moeda $\mathrm{e}$ caracteriza-se por sua volatilidade. O capital físico, também considerado importante, inclui infra-estrutura, máquinas, equipamentos e benfeitorias que 
fazem parte do processo produtivo. O capital natural, originalmente relacionado com a terra, perdeu importância relativa frente ao avanço tecnológico e à industrialização, por isso, segundo Prugh (1995) ${ }^{2}$, citado por Bernardes (2002) foi desconsiderado por Solow e outros autores neoclássicos. Em momento posterior essa condição foi revisada e mereceu maior atenção dos autores, tendo sido incluídos os recursos naturais nessa forma de capital. Ao longo do tempo, os modelos de crescimento têm procurado identificar, dimensionar e avaliar o comportamento das diferentes formas de capital na consecução do produto. Mais recentemente, os modelos de crescimento passaram a considerar, também, o capital humano através da educação e qualificação dos indivíduos envolvidos no processo produtivo. Nesse contexto de crescimento, a infra-estrutura pública de transporte pode ser entendida como parte fundamental do capital físico.

O desenvolvimento econômico, por sua vez, pode ser entendido como a promoção de benefícios econômicos e sociais e de bem-estar à população, através do uso do produto e da renda por ela gerada no processo de crescimento econômico. O acesso a produtos e serviços de boa qualidade em termos de alimentação, habitação, vestuário, saúde, educação, transporte, cultura e lazer, reflete o nível de desenvolvimento econômico de uma população em determinada região, num período de tempo definido. Na literatura, as definições, com algumas variações e particularidades, são próximas a esta. Como exemplo, Bernardes (2002) ressalta a definição de Sen (2000) ${ }^{3}$ que o entende como um processo de "expansão das liberdades reais desfrutadas pelas pessoas". Sob essa ótica o crescimento econômico, representado pelo aumento do produto nacional ou das rendas individuais, constitui-se, na verdade, em instrumento do desenvolvimento, ao favorecer trocas mutuamente benéficas e a atuação de redes de segurança social. Nesse contexto, a

\footnotetext{
${ }^{2}$ PRUGH, T. Natural capital and human economic survival. Solomons: International Society for Ecological Economics, 1995. 198p.

${ }^{3}$ SEN, A. Desenvolvimento com liberdade. São Paulo: Companhia das Letras, 2000. 409p.
} 
disponibilidade de infra-estrutura pública, especialmente a de transporte, é fundamental para garantir a acessibilidade da população aos produtos e serviços disponibilizados pelo crescimento.

\subsection{Definição de infra-estrutura pública de transporte}

Esclarecidos crescimento e desenvolvimento econômicos, pode-se dar seguimento à definição de infra-estrutura pública de transporte e à caracterização de alguns de seus aspectos particulares. Sobre a definição, Ahmed \& Donovan (1992, p.2) citando Hirschman (19584) argumentam que o significado de infra-estrutura pode ser dado pela natureza dos serviços que ela presta à sociedade, ou seja, "serviços fornecidos praticamente em todos os países, por agências públicas ou privadas sujeitas ao controle público, que não podem ser importados e cujos investimentos necessários ao seu fornecimento são caracterizados pelo tamanho e indivisibilidade". Dessa definição depreende-se que a dimensão espacial da infra-estrutura pública deriva da natureza do serviço a que ela se destina. Os autores ressaltam que a finalidade desses serviços é facilitar ou servir de base para atividades econômicas, fornecendo o ambiente básico para a atividade produtiva de indivíduos e empresas. Na sua maioria, observam, os serviços são livres de taxas e encargos ou, então, submetidos a taxas publicamente reguladas, por se tratar de um bem de natureza eminentemente pública mas, freqüentemente, de realização, administração e utilização privadas.

\footnotetext{
${ }^{4}$ HIRSCHMAN, A.O. Strategy of economic development. New Haven: Yale University Press, 1958. 217p.
} 
A realização de investimentos em infra-estrutura pública envolve aspectos relacionados à exigência de eficiência técnica na sua implantação e operação e à natureza do serviço que ela presta à população. Segundo Ahmed \& Donovan (1992), a decisão sobre investimentos em infra-estrutura pública confronta questões típicas relacionadas ao nível de recursos a ser alocado, à técnica de menor custo para sua construção, à localização mais eficiente dos vários elementos, aos valores para sua manutenção e ao desenvolvimento político e institucional necessário para essa construção e manutenção. Wharton Júnior (1975) salienta que os serviços de infra-estrutura devem ser oferecidos de modo uniforme, favorecendo a obtenção de economias de escala e de benefícios sociais. Nesse contexto, Pires \& Piccinini (1999) assinalam que os projetos de infra-estrutura pública são intensivos em capital, têm significativos custos irrecuperáveis (sunk costs) e longo prazo de maturação. Além disso, por serem considerados essenciais à população, com importantes externalidades, os serviços públicos de infra-estrutura estão sujeitos à "obrigação jurídica de fornecimento" o que, muitas vezes, faz com que a relação benefício-custo privada seja inferior à social, levando a um investimento inferior ao socialmente adequado. Diante disso, verifica-se uma histórica e significativa participação governamental na oferta de infra-estrutura de uso público, especialmente no Brasil.

No que respeita à oferta de infra-estrutura pública é, também, importante destacar que ela exige elevada capacidade técnica e financeira para sua implantação, operação e manutenção, o que reduz, naturalmente, o número de ofertantes habilitados a essas tarefas. Nesse contexto, Wharton Júnior (1975) salienta que isso faz com que a infra-estrutura pública, freqüentemente, seja provida por grupos privados altamente conceituados sob observação do governo para evitar uma excessiva concentração de poder por parte desses grupos, o que prejudicaria a oferta dos serviços em nível socialmente desejável. No que respeita à questão financeira, Dailami \& Klein (1997) assinalam que os 
projetos de infra-estrutura, tipicamente, requerem grande aporte de investimentos que demandam longos períodos de tempo para sua recuperação, expondo os investidores a diferentes tipos de riscos, inclusive o de que as autoridades públicas não honrem seus acordos sobre políticas de tarifas ou de pagamentos. Esses fatores de risco podem explicar o ciclo de privatizaçãonacionalização-privatização, conhecido como barganha obsolescente, a que se submetem as infra-estruturas destinadas à prestação de serviços públicos, especialmente em países pouco desenvolvidos ou em desenvolvimento.

O conhecimento dos aspectos inerentes à natureza da infra-estrutura pública e aos serviços que ela proporciona, permite aos tomadores de decisão governamental estabelecer estratégias de atração de parcerias privadas para a implantação e operação da infra-estrutura pública, de modo a estimular a distribuição de atividades econômicas entre diferentes regiões, combater 0 subdesenvolvimento e obter um processo de desenvolvimento econômico mais homogêneo. Sob essa questão, Henderson et al. (2001) assinalam que subdesenvolvimento e desenvolvimento econômico estão relacionados à alocação irregular de empresas e atividades econômicas explicada pelas relações espaciais entre as diferentes unidades econômicas e pelas diferenças institucionais e de dotações naturais e de capital físico e humano acumulados. Nesse sentido, considerando que um dos fatores que definem a escolha das firmas na produção em determinadas regiões é a presença de retornos crescentes à escala, enfatiza-se o argumento de Caixeta-Filho \& Martins (2001) ao assinalarem que uma infra-estrutura adequada e disponível, especialmente em transporte, potencializa ganhos de eficiência ao sistema produtivo como um todo, graças ao aumento do produto final, incremento da produtividade e à redução do custo por unidade de insumo transportado. Esse aumento de produtividade se reflete em remunerações mais elevadas aos fatores locais, estimulando a geração de empregos, a distribuição de renda e a atração de novos investimentos. Compartilhando essa visão, Henderson et al. (2001) 
assinalam que o investimento em infra-estrutura pública, principalmente em sistemas de transporte inter-regional, é um importante instrumento político que possibilita influenciar a dinâmica de localização urbana. À medida que uma área originalmente ocupada torna-se congestionada e sujeita a retornos decrescentes para novos investimentos, a ampliação da oferta de infra-estrutura pública se faz necessária para direcionar o crescimento a outras regiões. Sob esse ponto de vista, os autores defendem investimentos em rodovias, ferrovias ou hidrovias para influenciar as decisões de localização das firmas, favorecer a alocação mais adequada da produção e oferta de produtos e serviços, contribuir para o crescimento e distribuição da renda e elevar a concessão de benefícios à população de modo geral. A seguir, desenvolve-se uma discussão mais aprofundada sobre essa relação entre infra-estrutura de transporte e o crescimento e o desenvolvimento econômicos.

\subsection{Infra-estrutura de transporte no processo econômico}

A contribuição da infra-estrutura de transporte para o crescimento e desenvolvimento econômicos se realiza através dos serviços que ela presta, direta ou indiretamente, aos diferentes agentes e segmentos da sociedade. Conforme Eberts (2000), a interface entre investimentos em transporte e desenvolvimento econômico tem ramificações que vão além dos objetivos básicos de transportar pessoas e bens de um lugar para outro. Ainda que não haja dúvidas de que um eficiente sistema de transporte seja essencial para o funcionamento e crescimento de uma economia de mercado, muito ainda precisa ser entendido sobre sua contribuição ao processo de desenvolvimento como um todo. Segundo Brasil (2003c), transporte, crescimento e desenvolvimento econômico podem ser associados através dos chamados corredores estratégicos de desenvolvimento. Esses corredores são lugares ou eixos onde negócios podem ser viabilizados através de investimentos e da 
constituição de mercados produtores e consumidores, utilizando facilidades econômicas e sociais tais como um sistema viário adequado sob a forma de corredor de transporte, composto por rotas modais e multimodais que permitam o transporte de cargas em sua área de influência ${ }^{5}$. Neste sentido, World Bank (1997) observa que projetos de transporte são, geralmente, destinados a aumentar o bem estar econômico e social das pessoas. Ao aumentar a capacidade dos sistemas de transporte pode-se reduzir o tempo de viagem e diminuir o custo de uso dos veículos, enquanto aumenta o acesso aos serviços de mercado, empregos, educação e saúde e reduzem os custos de transporte de cargas e de passageiros. Todavia, Adler (1978) alerta que, ainda que a infraestrutura de transportes seja um pré-requisito para o crescimento, de maneira alguma ela constitui uma garantia do desenvolvimento econômico.

Em se tratando de crescimento econômico, ainda que a importância do sistema de transporte seja reconhecida, seu papel e impactos têm sido motivo de debate. Gannon \& Liu (2002) afirmam que o debate centra-se no tipo de papel que o serviço de transporte cumpre, qual seja: condutor, quando estimula o crescimento econômico através de seus efeitos de ampliação de mercados; ou, complementar, quando atende ao crescimento da demanda. Além disso, assinalam que o serviço de transporte é também complementar à disponibilidade de outros serviços meritórios básicos tais como saúde, educação e assistência social, sendo que a efetividade destes depende, significativamente, da acessibilidade do transporte à população, especialmente a de baixa renda. Diante disso, observam os autores, investimentos no setor de transporte podem melhorar o acesso às oportunidades econômicas através da redução dos custos de transporte, implicando menores preços de mercado para

\footnotetext{
${ }^{5}$ Definida como os espaços físico, biótico e antrópico suscetíveis de alterações decorrentes da implantação, manutenção e operação do empreendimento de transporte. Sob influência direta do empreendimento consideram-se as áreas em que os efeitos são produzidos por uma ou mais atividades tecnológicas do empreendimento. As áreas onde os efeitos são induzidos pela existência do empreendimento e não por uma atividade específica, são definidas como sob influência indireta.
} 
os produtos finais, ampliação espacial do mercado devido às mudanças induzidas nos padrões de produção e consumo, alta mobilidade pessoal e estímulo às atividades socio-econômicas. Em geral, pode-se esperar que esse processo dinâmico beneficie a todos os grupos de renda da sociedade na forma de efeitos reais de renda e aumento de oportunidades. Numa visão ampla, Caixeta-Filho \& Martins (2001) afirmam que a infra-estrutura de transporte beneficia a sociedade pela maior disponibilidade de bens; extensão dos mercados; aumento da concorrência; diminuição dos custos das mercadorias; especialização geográfica da produção; e, aumento da renda da terra. Além disso, produz benefício social pela mobilidade das pessoas, das informações e das idéias, sendo vista como um dos condicionantes da distribuição da população vis-à-vis a distribuição dos recursos, topografia e o desenvolvimento do comércio. Complementando, Tobias (1999) argumenta que o sistema de transporte articula produção e consumo, sob a lógica do sistema econômico vigente, da organização e do nível de desenvolvimento do espaço em que se situa. Isso condiciona a dinâmica de mudanças no sistema de transporte às mudanças espaciais futuras, ainda que com certa defasagem em tempo.

Contribuições mais específicas dos serviços proporcionados pela infra-estrutura de transporte ao crescimento econômico podem ser evidenciadas sob a ótica microeconômica. Gannon \& Liu (2002) afirmam que os investimentos em transporte diminuem os custos dos insumos intermediários da produção de diferentes localizações, reduzindo diretamente o custo de produção. Custos menores e melhoria na qualidade dos serviços de transporte também diminuem o preço de entrega dos produtos, aumentam as economias de escala e, assim, promovem o comércio regional e inter-regional. Investimentos em transportes contribuem para a diversificação da economia, bem como tornam possível a exploração de economias de escopo, permitindo o aumento das habilidades econômicas para negociar riscos. Nesse ambiente microeconômico, Wharton Júnior (1975), observa que quando existem grandes 
economias externas à escala, a provisão de serviços de infra-estrutura pode alterar bastante a rentabilidade particular e social de um empreendimento. A mudança na infra-estrutura pode, portanto, ser tratada analiticamente da mesma forma que uma mudança em tecnologia na teoria tradicional da firma. Quando favorável, constitui um deslocamento para baixo das curvas de custo da firma ou da indústria. Enquanto algumas mudanças de infra-estrutura afetam somente a parte de custo - melhoramento de estradas e de facilidades de transporte reduzindo as perdas no transporte e o custo de aquisição de insumos, outras afetam a forma e a posição da função de produção seja diretamente, através de pesquisas que alterem a produção, seja indiretamente, através de programas que alterem os níveis de oferta e retorno efetivos no mercado.

A colaboração da infra-estrutura de transporte ao processo de crescimento econômico também é aferida em nível macroeconômico por diferentes autores. Caixeta-Filho \& Martins (2001), por exemplo, argumentam que os serviços de transporte desempenham papel fundamental nas principais políticas públicas, tais como a exploração de recursos, divisão do trabalho, aumento do valor da terra e produção em larga escala. Eberts (2000), por sua vez, assinala que os efeitos do transporte também alcançam o meio ambiente ao influenciar o modo de vida das pessoas e a localização dos negócios, o que se reflete, por exemplo, nos padrões de ocupação do solo, de uso dos recursos naturais ou da qualidade do ar e da água. Nesse contexto, Gwilliam (1998) ressalta a necessidade de se assegurar uma provisão de transporte que seja sustentável econômica, ambiental e socialmente. Segundo ele, a sustentabilidade econômica requer que o núcleo de infra-estrutura de transporte se mantenha em estado operacional efetivo e que a infra-estrutura seja gerenciada para a provisão de serviços de transporte. A sustentabilidade ambiental necessita que as atividades do setor de transporte não coloquem em perigo, no longo prazo, a disponibilidade e a qualidade do ambiente físico 
(água, ar, solo e biodiversidade). A sustentabilidade social necessita que todos os grupos da população se beneficiem dos serviços de transporte no processo de desenvolvimento. Observados esses requisitos, a contribuição dos serviços de transporte é ampla e universal.

Os efeitos positivos, micro e macroeconômicos, dos serviços prestados pela infra-estrutura pública de transporte dependem, fundamentalmente, de que os custos da sua utilização não sejam impeditivos ao acesso dos usuários aos mercados de fatores de produção e de produtos e serviços. Segundo Castro (2001), os custos de transporte estão entre os fatores que limitam os fluxos de comércio, influenciando os custos dos insumos, da produção e, conseqüentemente, o preço final dos bens.

É interessante considerar que os custos dos serviços de transporte são decorrentes, muitas vezes, da própria estrutura de oferta desse tipo de infra-estrutura. Estache \& Rus (2000) lembram que há fortes restrições tecnológicas limitando as oportunidades de competição no setor de infraestrutura de transporte e isso coloca aos reguladores a dificuldade de substituição de um monopólio público global por pequenos e especializados monopólios privados ou, mesmo, públicos. Os limites desses pequenos monopólios são dados pela presença de forte indivisibilidade, produção conjunta e dificuldade de armazenar serviços de transporte. Isso é o que, essencialmente, dirige a estrutura de custos da infra-estrutura de transporte. Essa estrutura de custos está, freqüentemente, sujeita à alocação arbitrária de papéis através de linhas de serviços, tipos e grupos de usuários. Em muitos países, afirmam os autores, o setor público projeta, constrói e opera estradas, ferrovias, aeroportos e portos, como uma forma de regulação do setor. Uma das alegações para a continuidade dessa intervenção governamental no setor de transporte é o receio de que os usuários fiquem expostos a abusos devido a serviços monopolizados por operadores privados, uma vez que o transporte de cargas e de passageiros tem poucos substitutos. Contudo, esse tipo de 
intervenção tem, geralmente, resultado em excessivos custos que não são usualmente compatíveis com preços ou qualidade, refletindo mais os interesses de alguns grupos civis empregados no setor de construção, do que as preferências dos usuários e contribuintes.

Custos elevados nos serviços de transporte prejudicam a sociedade como um todo e, especialmente, a população mais pobre. Gannon \& Liu (2002) observam que altos custos de transporte podem significar isolamento geográfico, social e econômico, tornando-se um obstáculo, especialmente para os grupos de baixa renda. Em áreas rurais pobres, a falta de transporte confiável penaliza famílias na produção de culturas comerciais, na obtenção de oportunidades de empregos não rurais e no acesso aos serviços sociais. Gwilliam (1998) salienta que a precariedade da infra-estrutura de transporte amplia os problemas ambientais das cidades e das populações, principalmente, a mais pobre. Essa precariedade, comum em países em desenvolvimento resulta da manutenção inadequada realizada por empresas estatais ou sob regulamentação pública que operam com aporte equivocado de recursos ou desenvolvem serviços de baixa qualidade. Esse procedimento, ao longo do tempo, leva à deterioração da infra-estrutura de transporte até um estado quase inutilizável, prejudicando a sociedade que dela necessite para crescer se desenvolver. Gannon \& Liu (2002) ressaltam que, sendo o transporte um serviço intermediário, ele exerce papel crucial na redução da pobreza absoluta quer pela diminuição de custos operacionais e de preços de insumos e produtos, quer pelo aumento do acesso a novas oportunidades pessoais e profissionais. Porém, eles alertam que, tipicamente, projetos de transporte são elaborados com foco na redução de custos do transporte, no aumento da eficiência e na promoção do crescimento econômico. A contribuição das operações de transporte para a redução da pobreza é vista, em geral, como indireta e derivada de um amplo desenvolvimento econômico, desconsiderando-se que o transporte é um insumo básico na redução da 
pobreza através da construção de escolas e hospitais ou da implantação de programas de nutrição e serviços sociais.

A relação entre o custo e o benefício dos serviços fornecidos pela infra-estrutura de transporte pode ser, também, analisada sob o ponto de vista do desenvolvimento regional. Nesse contexto, Castro (2001) observa que, no caso de regiões que tenham sua base produtiva assentada em produtos primários, o impacto do transporte é ainda mais significativo, uma vez que o valor de mercado de seus produtos, em relação ao próprio peso, é menor, tornando o valor do frete mais oneroso em relação aos preços finais. Além disso, grande parte dos produtos primários tem seu preço determinado pelo mercado internacional, o que dificulta o repasse de aumentos de custos de transporte para os preços finais. Dessa forma, os custos de transporte definem as regiões capazes de concorrer nos diferentes mercados e afetam os preços dos bens e a geração de renda regional. Com preocupação semelhante, Bougheas et al. (1999) ressaltam que os custos de transporte estão inversamente relacionados à disponibilidade regional de infra-estrutura de transporte de qualidade. Em relação ao volume de comércio, observaram uma associação positiva com a oferta de infra-estrutura. De modo geral, Limão \& Venables (2002) lembram que os custos de transporte dependem de muitos detalhes locais relacionados à geografia, infra-estrutura, barreiras administrativas e estrutura de remessa industrial. Regiões interiores, por exemplo, sem acesso aos portos, estão em desvantagem, embora sejam capazes de superá-la parcialmente caso a infra-estrutura de transporte das regiões vizinhas, que fazem a interligação, seja de boa qualidade e alta capacidade. Diante disso, pode-se concordar com Laksmanan et al. (2001) quando afirmam que investimentos na modernização de ferrovias, melhorias das estradas, portos, hidrovias internas e aeroportos, bem como a coordenação intermodal, poderiam eliminar as deficiências e desigualdades da infra-estrutura de transportes entre regiões e países. 
De modo geral, as observações até aqui reunidas convergem para a importância da participação do transporte no processo de crescimento econômico. Além disso, evidenciam que os serviços prestados pela infraestrutura de transporte possibilitam o acesso de pessoas e regiões a produtos e serviços, assim como estimulam a criação de oportunidades de mercado que podem culminar em negócios, empregos, renda, consumo e produção de novos produtos e serviços, fomentando um ciclo virtuoso na economia. Associada a esse ciclo estabelece-se uma possibilidade de maior arrecadação fiscal e de gastos públicos com a oferta de serviços públicos básicos à sociedade, concretizando um processo saudável de desenvolvimento econômico. Reunidos, esses aspectos assinalam para a validade econômica e social dos investimentos em infra-estrutura de transporte.

O investimento na formação de infra-estrutura pública de transporte está relacionado às características particulares da infra-estrutura e do sistema de transporte onde ela se insere. Segundo Caixeta-Filho \& Martins (2001), os investimentos em infra-estrutura de transporte devem ser definidos segundo o critério da produtividade, selecionando-se os projetos mais produtivos. Esses autores afirmam que a busca pela competitividade nos mercados externos reforça a discussão sobre a estrutura de divisão modal de cargas e de passageiros. Essa realidade exige modais de transporte operacionalmente eficientes e de menores custos de deslocamento de mercadorias entre origens e destinos, premiando a intermodalidade. Sobre esse aspecto, a Administração das Hidrovias do Tocantins e Araguaia (AHITAR) (1999) afirma que nenhum modal de transporte é melhor do que outro. Rodovia, ferrovia e hidrovia não concorrem entre si. Na realidade, a opção por investimento em um determinado modal depende das injunções de logística que articulam a multimodalidade, no sentido de obter eficiência, eficácia e redução de custo no deslocamento de cargas. Em longas distâncias é a combinação de pelo menos dois modais que permite uma adequação econômica que leva à sustentabilidade. Nesse 
contexto, Laksmanan et al. (2001) realçam que o investimento na consolidação de um efetivo sistema intermodal de transportes reduziria obstáculos físicos dos corredores custo-efetivos potenciais, tais como: ausência de travessias; pontes estreitas e frágeis; iluminação precária; trechos rodoviários sem manutenção; rede ferroviária com diferentes bitolas; sinalização hidroviária inadequada; e, condições precárias para transbordo e armazenamento de carga. Diante disso, afirmam que investimentos na modernização das ferrovias, estradas, portos, hidrovias internas e dos aeroportos, bem como a coordenação intermodal, eliminariam essas deficiências na infra-estrutura pública de transportes e potencializariam seus benefícios à sociedade.

Dos argumentos expostos, depreende-se que a existência de uma infra-estrutura pública de transporte adequada em termos de finalidade, qualidade, capacidade e intermodalidade é condição necessária ao crescimento e desenvolvimento econômicos. Essa constatação eleva a responsabilidade do processo de avaliação e seleção dos projetos de implantação de infra-estrutura, no sentido de possibilitar aos tomadores de decisão a melhor ordenação e escolha dos projetos a serem implantados. Essa responsabilidade se torna ainda maior quando se considera a limitada disponibilidade pública e privada de recursos materiais e financeiros da sociedade. Nesse contexto, torna-se fundamental conhecer os principais métodos de avaliação de projetos de infraestrutura pública de transporte, bem como, compreender suas potencialidades e limitações, como se faz no Capítulo a seguir. 


\section{AVALIAÇÃO DE PROJETOS DE INFRA-ESTRUTURA DE TRANSPORTE}

As considerações apresentadas até este ponto realçam a importância dos serviços prestados pela infra-estrutura pública de transporte como instrumento de crescimento e desenvolvimento econômicos. Essa constatação, conseqüentemente, encaminha a discussão para os métodos de avaliação, ordenação e escolha de projetos de implantação e operação desse tipo de infra-estrutura. Esse é o propósito deste Capítulo.

\subsection{Importância da avaliação econômica de projetos de infra-estrutura}

A importância da avaliação econômica de projetos de infra-estrutura está relacionada com o tipo e a abrangência dos impactos econômicos e sociais que a infra-estrutura em análise possa causar. Assim, quanto maiores o número e a intensidade dos impactos esperados, mais importante se torna o processo de avaliação. Dentre os autores que compartilham dessa visão, Adler (1978) ressalta que a avaliação econômica de projetos assume particular importância quando considerados o significado estratégico, os grandes investimentos necessários e, freqüentemente, os pesados encargos em moeda estrangeira envolvidos na implantação de infra-estruturas. Gannon \& Liu (2002), por sua vez, destacam a necessidade da avaliação considerar, também, os impactos distributivos de curto e de longo prazos dos projetos de infra-estrutura, favorecendo a tomada de decisão. Para isso, Eberts (2000) recomenda o uso de ferramentas analíticas que focalizem questões de eficiência e eqüidade e 
incluam componentes de desenvolvimento econômico, tais como mudança no emprego, abertura e fechamento de empresas e renda pessoal promovidas, direta ou indiretamente, pela infra-estrutura. Vale observar que a literatura sobre o assunto mostra enorme preocupação com os mecanismos de avaliação mas, segundo Ahmed \& Donovan (1992), não ilumina, suficientemente, os métodos de identificação e de mensuração dos benefícios diretos e indiretos da infraestrutura.

A avaliação econômica de projetos de implantação de infra-estrutura deve considerar as especificidades do setor que o projeto pretende atender para avaliar a validade de sua inserção nesse setor. Conforme Adler (1978), essa avaliação exige previsões, o que, inevitavelmente, exige a determinação dos graus de incerteza e de risco dos eventos e, com isso, o conhecimento de sua distribuição probabilística. No caso da infra-estrutura de transporte, Gannon \& Liu (2002) recomendam que os métodos de avaliação observem se os projetos avaliam as características das populações afetadas, as estruturas de mercado relevantes, os impactos distributivos da infra-estrutura e sua integração com outros setores da economia.

\subsection{Métodos de avaliação econômica de projetos de infra-estrutura}

Dentre os métodos de avaliação econômica de projetos, a análise benefício-custo é o mais tradicionalmente utilizado. Esse método procura estabelecer o fluxo de benefícios e custos esperados ao longo de um horizonte temporal definido para o projeto, considerando, também, uma taxa de desconto que representa o custo de oportunidade dos recursos empregados.

O uso universal da análise benefício-custo estimula uma robusta discussão a respeito de suas potencialidades e, principalmente, de suas limitações. Weisbrod \& Grovak (2001), por exemplo, assinalam que a teoria 
econômica é muito clara sobre utilizar a análise benefício-custo na seleção de projetos, orientando a escolha para aquele que otimize o benefício líquido. Entretanto, a existência de diferentes aproximações e pontos de vista que, em parte, dependem de como os objetivos e metas dos projetos foram estabelecidos, afetam a definição dos benefícios. Diante disso, recomendam considerar, pelo menos, quatro pontos-chave relacionados à essa definição:

a) quais objetivos - prosperidade econômica, qualidade de vida, meio ambiente, segurança, confiança?

b) quais pontos de vista - local, estadual, regional, nacional, global?

c) quem serão os beneficiados - residentes, negociantes, viajantes, outros?

d) qual a dimensão de tempo - para as gerações presentes ou futuras?

Os autores alertam que responder a cada uma dessas questões, na prática, é bem mais complexo do que na teoria econômica básica. As principais dificuldades estariam no fato de que os benefícios, na sua totalidade, não podem ser expressos em termos de disposição a pagar do consumidor, mensurados para toda a sociedade, compensados através do pagamento dos beneficiados aos prejudicados ou calculados em termos de valor presente líquido.

Em uma visão geral sobre a análise benefício-custo, vários autores assinalam a necessidade de ampliação do espectro das análises e, principalmente da benefício-custo, no sentido de elevar a sensibilidade da análise e a qualidade das inferência e respectivas decisões. Com efeito, Ahmed \& Donovan (1992) salientam que, sendo uma aproximação orientada ao projeto, a análise benefício-custo focaliza um elemento particular dentre vários, perdendo, todavia, o efeito da interação entre eles. No caso de projetos de infra-estrutura de transporte, eletrificação ou de comunicação, a maioria das 
aproximações é dirigida para a captação dos efeitos diretos, enquanto a dos indiretos ou externalidades permanece como um desafio empírico. Além das dificuldades metodológicas de identificação, captação e mensuração desses efeitos, outras razões poderiam explicar a possível resistência à inclusão de efeitos monetários e não-monetários dos aspectos intangíveis nos processos de avaliação, seja pelo aumento no tempo e gastos de elaboração dos projetos, seja pelo receio de que os resultados qualitativos reflitam alguma inadequação da proposta. Dentre essas razões, Nakamura (2000) ao avaliar investimentos governamentais em infra-estrutura de transporte realizados no Japão destaca alguns:

a) a priorização do atendimento da demanda de curto prazo de infra-estrutura de transporte, gerando uma oferta insuficiente frente à taxa de crescimento econômico;

b) o uso do investimento público em infra-estrutura de transporte apenas como instrumento de geração de empregos e não como gerador de estoque de capital de transporte para uso da sociedade; e,

c) a tentativa de utilizar o investimento em infra-estrutura de transporte como instrumento político de influência do eleitorado local, criando resistências aos processos de avaliação ampla e, principalmente, qualitativa dos impactos;

A utilização de métodos reduzidos de avaliação econômica pode comprometer os resultados da análise e, por conseqüência, a tomada de decisão sobre a infra-estrutura de transporte. Uma decisão equivocada na implantação da infra-estrutura de transporte pode prejudicar a implantação de um sistema de transporte intermodal que beneficie a sociedade. Sobre esse aspecto, Morisugi (2000) observa que inconsistências na análise dificultam seu desenvolvimento sob o ponto de vista da eficiência e da equidade. Dessa forma, a avaliação fica, principalmente, baseada na eficiência econômica, 
sendo a eqüidade apenas vagamente considerada. Eberts (2000), por sua vez, assinala que os resultados das análises devem ser compreensíveis a diferentes profissionais e tomadores de decisão, de modo que possam compreender o valor desses conceitos em suas operações, facilitando a apreciação dos efeitos das decisões de investimento em transporte.

O entendimento do projeto por diferentes avaliadores e tomadores de decisão é uma exigência que se impõe sobre o método de avaliação e, por isso, uma preocupação recorrente na literatura. Quem muito bem a expressa e discute é Nakamura (2000). Esse autor observa que, na medida em que há grandes diferenças entre os países em relação ao escopo, métodos de avaliação e impactos sobre a tomada de decisão a respeito da infra-estrutura pública, algumas questões devem ser consideradas no sentido de se obter um método que possibilite uma comparação internacional entre os projetos:

1. sobre a metodologia

a) quais itens devem ser avaliados?

b) quais os itens não-comercializáveis e os impactos econômicos indiretos na região avaliada?

c) quais itens são monetários e quantificáveis?

d) quais são os resultados de uma avaliação monetária que incorpora os impactos ambientais e outros valores não-comercializáveis?

e) qual método deve ser utilizado para integrar vários itens monetários e nãomonetários?

f) qual conceito de contagem baseia a análise benefício-custo utilizada (preço de mercado, preço-sombra dos recursos ou disposição à pagar)? 
g) qual a escala de mensuração de parâmetros como tempo de viagem e danos por acidentes de tráfego?

2. sobre a utilização dos resultados da avaliação na tomada de decisão

a) qual a extensão da avaliação?

b) como os resultados devem ser utilizados na tomada de decisão?

c) para quem deve ser revelado o conteúdo da avaliação?

d) quem deve ser o responsável pelo julgamento dos resultados?

Consideradas essas questões, Nakamura espera que projetos com amplos efeitos sejam desenvolvidos, enquanto aqueles com efeitos menos significativos sejam rejeitados.

\subsection{Avaliação econômica de projetos de infra-estrutura de transporte}

Diante da importância dos projetos de infra-estrutura pública de transporte para o crescimento e desenvolvimento econômicos, bem como a magnitude dos investimentos necessários à sua implantação, torna-se fundamental que o processo de avaliação econômica desse tipo de projetos seja o mais amplo e completo possível. Dessa forma, espera-se que seja favorecida uma tomada de decisão de melhor qualidade sob os pontos de vista econômico, social e ambiental.

O método de avaliação deve considerar as especificidades do setor que analisa, como objetivo de aumentar a sensibilidade da análise e favorecer uma decisão de maior qualidade. Em se tratando de aspectos particulares aos serviços de transporte, é preciso considerar que eles acontecem em um espaço 
determinado, dentro de uma área geográfica específica e que seu uso está relacionado ao movimento de bens e pessoas entre dois pontos. Além disso, devido ao fato dos serviços de transporte serem providos dentro de uma rede ou sistema, o que acontece em um local afeta os acontecimentos em outro. Daí, segundo Eberts (2000) os métodos devem ter atenção à correspondência espacial entre infra-estrutura de transporte e atividade econômica. A falta de informação sobre a ligação entre negócios e residências e os sistemas de transporte estimula uma agregação em torno de uma "jurisdição governamental" e prejudica a criação de uma ligação espacial adequada entre usuários e sistema.

A importância dos serviços de transporte para a economia e sociedade é amplamente discutida na literatura e estimula a indicação de aspectos que devem ser contemplados pelos processos de avaliação econômica dos projetos de infra-estrutura de transporte. Weisbrod \& Grovak (2001), por exemplo, observam ser interessante a avaliação de diferentes aspectos dos projetos de transporte como, por exemplo, a possibilidade de investimentos alternativos, a convergência com objetivos de políticas públicas e a necessidade de modificações ou complementações que maximizem os impactos positivos potenciais e minimizem os negativos, de modo que se possa inferir, apropriadamente, seus potenciais benefícios. Os autores afirmam, ainda, que as análises podem focalizar-se em aspectos como: eficiência do sistema (benefício ao usuário); modelagem de simulação macroeconômica; produtividade; planejamento estratégico (cenários); ou, bem estar social (custo total). Por sua vez, Bruinsma \& Rietveld (1997) assinalam que, além da aproximação por modelos quantitativos o método deve avaliar as percepções empresariais sobre a infra-estrutura pública de transporte, verificando se são baseadas apenas em razões sólidas e objetivas como, por exemplo, os custos de transporte, ou se fatores subjetivos são, igualmente relevantes e considerados. Segundo os autores, pode-se, também, tentar captar se há 
diferenças entre a presença e a ausência da infra-estrutura, identificando sua contribuição em diversas variáveis econômicas, tais como: emprego, produtividade dos fatores de produção ou performance dos negócios das empresas. Além disso, os empresários podem ser convidados a expor suas expectativas com relação a futuros projetos de transporte.

Uma forma interessante de contabilizar possíveis impactos qualitativos do investimento em infra-estrutura de transporte sobre os agentes econômicos na área do projeto é proposta por Morisugi (2000), através do uso da matriz de benefícios incidentes. Segundo ele, o método possibilita julgar a eficiência do projeto sob o ponto de vista do benefício social líquido. Quanto maior esse benefício, maior a eficiência do projeto. Além disso, o balanço de equidade entre os agentes econômicos é avaliado segundo a distribuição dos benefícios líquidos. Assim, o projeto pode ser avaliado sob os critérios da eficiência e da equidade. Mais que isso, a distribuição dos benefícios líquidos pode sugerir a compensação ou a transferência de dinheiro entre os agentes econômicos, de modo a contrabalançar os impactos do projeto.

A análise por benefícios incidentes dos investimentos em infraestrutura pública de transporte proposta por Morisugi (2000) utiliza uma estrutura matricial onde os agentes econômicos direta e indiretamente afetados pela implantação da infra-estrutura pública de transporte são dispostos nas colunas e os efeitos diretos, indiretos e totais são dispostos nas linhas. Nessa abordagem, a soma das colunas fornece o benefício líquido obtido pelos agentes e a soma das linhas mostra o benefício líquido de cada efeito. A soma de todas as células da matriz reflete, assim, o benefício social líquido do investimento projetado, resultante dos benefícios líquidos dos efeitos diretos do uso das estradas e dos efeitos indiretos sobre o meio ambiente e vida civil dos usuários, residentes, produtores, trabalhadores e ocupantes dos espaços das estradas. Alguns efeitos relacionados à economia regional, ao gasto fiscal, ao retorno de taxas e ao subsídio público apresentam resultado final, em linha, 
igual a zero, uma vez que os benefícios proporcionados a alguns agentes econômicos são cancelados pelas perdas provocadas a outros, resultando em balanço igual a zero. O Quadro 1 apresenta a matriz de benefícios incidentes construída por Morisugi (2000) para analisar os investimentos em estradas no Japão, em 1999, com uma interpretação dos resultados através de símbolos. Sobre os resultados, o autor observa que os efeitos para os diferentes grupos podem ser negativos ou positivos e, muitas vezes, de difícil mensuração monetária, o que inibe a aplicação do método.

A fundamentação conceitual e algébrica do método de benefícios incidentes encontra-se em Morisugi \& Ohno (1995), onde os autores apresentam uma matriz genérica para projetos de desenvolvimento urbano e propõem o uso de um modelo multi-regional de equilíbrio geral que incorpore funções-utilidade dos usuários sobre a infra-estrutura analisada, combinado com um modelo logito para o tratamento das informações qualitativas. Segundo os autores, essa complexidade metodológica dificulta a utilização da matriz de benefícios incidentes na avaliação dos projetos de infra-estrutura pública de transporte. 


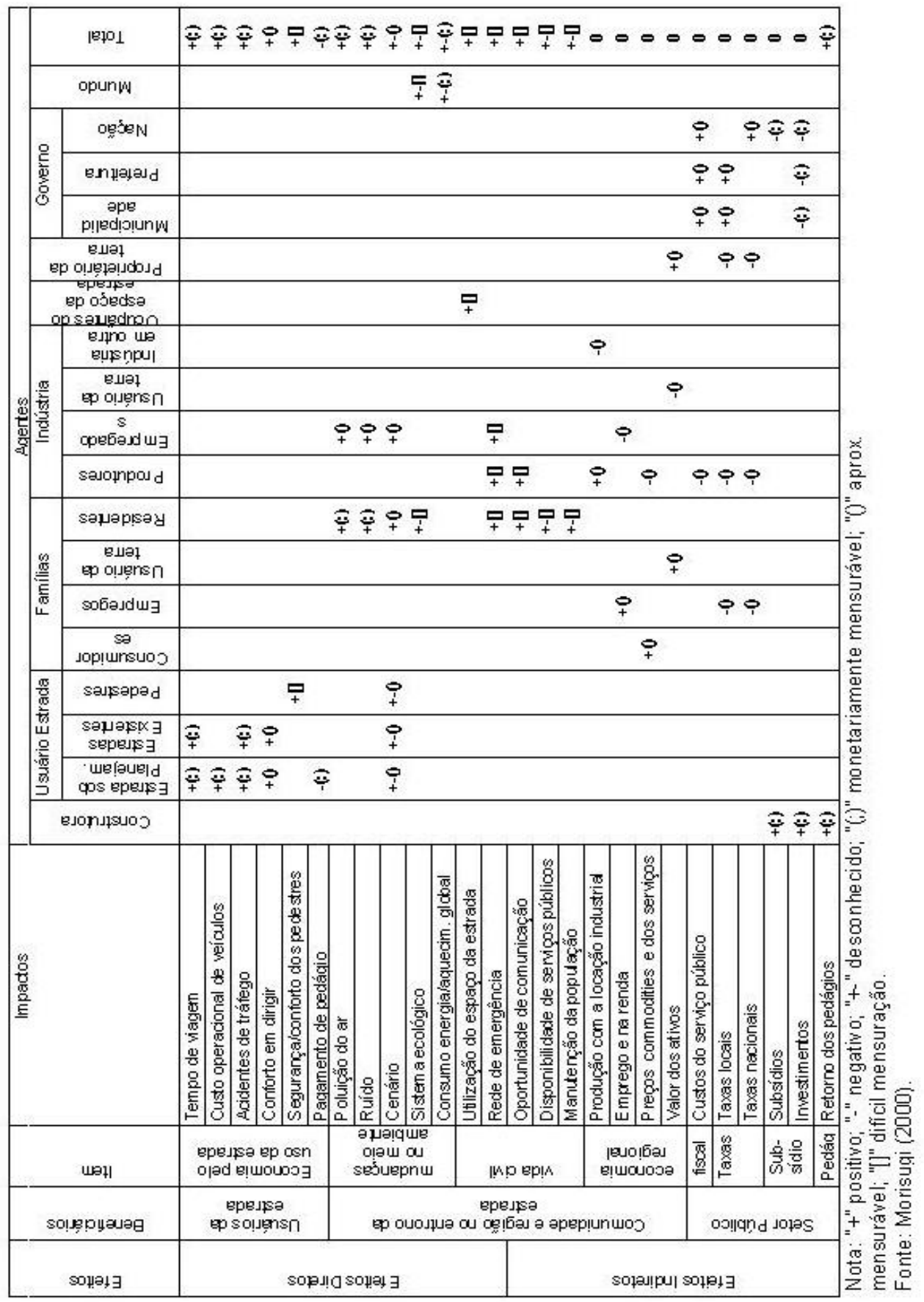

Quadro 1 - Benefícios incidentes em um projeto de investimento em estradas, Japão, 1999 
A análise matricial de projetos de infra-estrutura de transporte também pode ser feita através da utilização do método da Estrutura Lógica, aplicado por (ITAD) $(1996)^{6}$. Segundo Jackson $(1998)^{7}$ citado por Bernardes (2002), esse método permite representar um projeto na forma de uma matriz $4 \times 4$, cujos elementos possibilitam a avaliação através da utilização de critérios relacionados ao método científico, à análise de sistemas e ao ponto de vista da gerência de programas. A Estrutura Lógica pode ser aplicada no planejamento, elaboração, implementação e avaliação de projetos, fornecendo uma estrutura que facilita estabelecer prioridades e determinar resultados e atividades pretendidas. Permite, ainda, a avaliação da efetividade, da eficiência e da relevância do projeto. Bernardes (2002) argumenta que a Estrutura Lógica possibilita introduzir a incerteza na elaboração do projeto, fazendo com que as informações nele contidas explicitem os fatores incertos (pressupostos). Através da relação insumos-produtos-propósito sob a forma "se A então B", o método permite analisar as responsabilidades e correlações entre esses três níveis hierárquicos. Assim, ocorrendo a situação desejada em um nível hierárquico, correspondente aos pressupostos, outro nível do projeto é alcançado.

A representação genérica da matriz de Estrutura Lógica é apresentada no Quadro 2. Como se pode observar, o método utiliza como critérios os objetivos ou atividades propostos, os indicadores objetivos do projeto, os meios de verificação desses indicadores e os pressupostos necessários à consecução dos objetivos ou atividades. Bernardes (2002) salienta que, baseada nesses critérios, a Estrutura Lógica revela as inconsistências do projeto através de verificação de problemas não endereçados pelos objetivos, objetivos sem problema correspondente e diferenças em relações causa-efeito/meios-fins. Um aspecto particular do

\footnotetext{
${ }^{6}$ ITAD. The logical framework approach: a project management tool. S.I.: s.ed., 1996.

${ }^{7} \mathrm{JACKSON}$, B. Designing projects ans project evaluation using the Logical Framework Approach. Gland: IUCN, The World Conservation Union, 1998. http://www.iunc.org/themes/ eval/english/lfathtm (18 June 2001)
} 
método é que as informações utilizadas estão contidas no próprio projeto, o que impõe a necessidade de acesso físico ao documento original e/ou oficial. Como esse documento nem sempre está disponível, integral ou parcialmente, a aplicação da avaliação segundo a Estrutura Lógica fica prejudicada ou, muitas vezes, impossibilitada. Bernardes (2002) utilizou o método para analisar os planos de desenvolvimento regional direcionados ao Vale dos rios TietêParaná, principalmente no que respeita ao desenvolvimento turístico da Hidrovia Tietê-Paraná (Projetos Calha e Fomento). O autor concluiu que os planos, como um todo, não atendiam às exigências mínimas da Estrutura Lógica ao não explicar os pressupostos, não evidenciar indicadores objetivamente verificáveis e impossibilitar a detecção das responsabilidades pelas falhas.

\begin{tabular}{|c|c|c|c|}
\hline $\begin{array}{l}\text { Objetivos/ } \\
\text { Atividades }\end{array}$ & $\begin{array}{c}\text { Indicadores } \\
\text { Objetivos }\end{array}$ & $\begin{array}{c}\text { Meios de } \\
\text { Verificação }\end{array}$ & Pressupostos \\
\hline $\begin{array}{c}\text { Objetivos Globais } \\
\text { ou Fim }\end{array}$ & "n" Indicadores & $\begin{array}{l}\text { Meios de verificação } \\
\text { dos " } n \text { " indicadores }\end{array}$ & "k" pressupostos \\
\hline $\begin{array}{l}\text { Propósito } \\
\text { Do Projeto }\end{array}$ & "x" Indicadores & $\begin{array}{l}\text { Meios de verificação } \\
\text { dos "x" indicadores }\end{array}$ & "l" pressupostos \\
\hline $\begin{array}{l}\text { Resultados } \\
\text { Ou Produtos }\end{array}$ & "y" Indicadores & $\begin{array}{l}\text { Meios de verificação } \\
\text { dos "y" indicadores }\end{array}$ & "m" pressupostos \\
\hline $\begin{array}{l}\text { Atividades } \\
\text { Ou Insumos }\end{array}$ & "z" Indicadores & $\begin{array}{l}\text { Meios de verificação } \\
\text { dos "z" indicadores }\end{array}$ & "p" pressupostos \\
\hline
\end{tabular}

Quadro 2 - Matriz genérica de Estrutura Lógica

Fonte: Jackson (1998) citado por Bernardes (2002)

Vale observar que, a exemplo do que Bernardes (2002) fez com a Hidrovia Tietê-Paraná, a Estrutura Lógica seria um método interessante para a análise do projeto da Hidrovia Tocantins-Araguaia que é o objeto central deste 
estudo. Porém, para isso seria necessário ter em mãos o projeto dessa hidrovia, o que não foi possível obter. Apesar das várias tentativas efetuadas em diferentes instituições, tais como a empresa responsável pela implantação da infra-estrutura e os órgãos públicos licenciadores ou fiscalizadores do empreendimento, não foi possível obtê-lo na íntegra, impossibilitando o uso da Estrutura Lógica.

Considerados a importância, as particularidades e a adequação dos métodos de avaliação econômica de projetos de infra-estrutura pública de transporte, pode-se avançar, no Capítulo a seguir, para a caracterização do objeto de estudo desta pesquisa, qual seja, a Hidrovia Tocantins-Araguaia, no Estado do Tocantins, Norte do Brasil. 


\section{SISTEMA DE TRANSPORTE NO ESTADO DO TOCANTINS}

As considerações sobre a importância da infra-estrutura pública de transporte e da utilização de métodos de avaliação econômica de projetos adequados às particularidades desse tipo de infra-estrutura servem de base ao propósito deste estudo que é avaliar os impactos econômicos, sociais e ambientais da implantação da Hidrovia Tocantins-Araguaia, no Estado do Tocantins, sob o ponto de vista dos agentes econômicos municipais. Isto feito, a seqüência que se estabelece é a caracterização histórica e econômica do sistema de transporte no Estado e, em especial, da Hidrovia TocantinsAraguaia, o que constitui o objetivo principal deste Capítulo.

\subsection{Tocantins: aspectos históricos e econômicos}

Criado pela Constituição de 1988, o Estado do Tocantins tem sido palco de forte investimentos em infra-estrutura destinada à realização de serviços de transporte, comunicação e eletrificação urbana e rural. Constituído a partir do antigo norte goiano, o Tocantins faz parte da Região Norte do Brasil. Localizado em posição geográfica central no País, tem divisas com os estados do Pará, Maranhão, Piauí, Bahia, Goiás e Mato Grosso. Possui 139 municípios, sendo Palmas a capital.

A economia tocantinense tem por base a atividade agropecuária, com modesta colaboração dos setores de indústria e comércio. Segundo o 
INSTITUTO BRASILEIRO DE GEOGRAFIA E ESTATÍSTICA (IBGE) (2003), em 1999, o Tocantins foi responsável por apenas 0,22\% do Produto Interno Bruto (PIB) brasileiro. O PIB per capita tocantinense, registrado nesse ano, foi de R\$ 1.832,00, para uma população de cerca de um milhão e cem mil habitantes, equivalente a apenas $31 \%$ do PIB per capita brasileiro. Essa situação explica os esforços públicos e privados no sentido de promover o crescimento e o desenvolvimento econômicos do Estado.

O Tocantins possui características geográficas específicas que o caracterizam como eixo básico de uma rota de trânsito que interliga centros comerciais a canais internos e externos de distribuição comercial. Isso reflete a importância regional da escolha adequada da infra-estrutura a ser implantada e mantida em terras tocantinenses, tanto para uso próprio quanto para o atendimento dos demais estados da Federação. O Estado ocupa posição estratégica para os circunvizinhos alcançarem mercados consumidores internos e externos. Como região de trânsito, o Tocantins representa um elo de ligação entre áreas produtoras e consumidoras. Na medida em que disponha de infraestrutura de transporte adequada, a redução de custos na aquisição de insumos e no escoamento da produção será favorecida, aumentando a competitividade local e regional frente aos mercados doméstico e estrangeiro.

A navegação fluvial faz parte do contexto tocantinense muito antes da constituição do Estado. Os rios Araguaia e Tocantins serviram aos colonizadores portugueses como caminho de entrada para o norte do Brasil, na procura por pedras e metais preciosos, bem como por escravos indígenas. Além disso, nos trechos que era possível, a navegação nesses rios contribuiu para a formação de núcleos urbanos que, depois, tornaram-se municípios local e regionalmente importantes. A proximidade com o rio estimulou sua interação com a população local que o incorporou em suas atividades pessoais, tais como alimentação, transporte, pesca comercial e lazer. Diante disso, o uso dos rios 
como vias de transporte sempre representou uma proposição natural para a população da região. Diante disso, a implantação de uma hidrovia, entendida como canal de navegação estruturado para o transporte de passageiros e de carga, não se apresenta estranha aos contextos econômico, social e ambiental dos habitantes e das localidades.

\subsection{O sistema de transportes no Tocantins}

Segundo Tocantins (2002), a existência de um sistema de transportes de boa qualidade e capilaridade é fundamental para o aproveitamento das potencialidades do Tocantins, em termos de transporte intra e inter-estadual, de estímulo à produção agropecuária e industrial local, de aproveitamento de reservas minerais, de oferta de serviços de turismo. Nesse contexto, o Estado apresenta como modalidades de transporte a rodoviária, a aeroviária e a hidroviária. A ferroviária não existe no Estado e depende da construção da Ferrovia Norte-Sul. A Figura 1 ilustra a rede intermodal de transporte, existente e planejada para o Estado do Tocantins, em 1999.

A Figura 1, ao demonstrar a infra-estrutura pública de transporte no Tocantins, evidencia o domínio absoluto da malha rodoviária no transporte local de passageiros e cargas. Nessa malha, destaca-se, no sentido norte-sul do Estado, a rodovia BR-153, chamada de "Belém-Brasília", que corta o Estado de norte a sul, localizando-se à margem esquerda do Rio Tocantins. Ela constitui o principal eixo de transporte de passageiros e cargas e de ligação do Tocantins com o centro-sul do País. A BR 153 atravessa oito estados brasileiros, indo do Pará ao Rio Grande do Sul, conforme ilustra a Figura 2. No sentido leste-oeste, a interligação do Tocantins com os demais estados do País se realiza com a conclusão das rodovias BR-235 e BR-242. O traçado da BR-235 beneficia diretamente a região central do Tocantins, de grande potencial agrícola e as regiões sul do Pará e norte de Mato Grosso. Essa rodovia permitirá a ligação de 
Conceição do Araguaia, no Pará, ao sistema rodoviário do Nordeste, através do sul do Maranhão e Piauí, alcançando os municípios de Petrolina (PE) e Juazeiro (BA). A rodovia BR-242 atenderá a maior região agrícola do Tocantins, a planície dos rios Formoso e Javaés, ligando-a aos mercados leste e nordeste do País. Ela, igualmente, beneficiará a região sudeste do Estado, de solos férteis e onde existem indústrias de beneficiamento de calcáreo que também atendem o oeste da Bahia. 


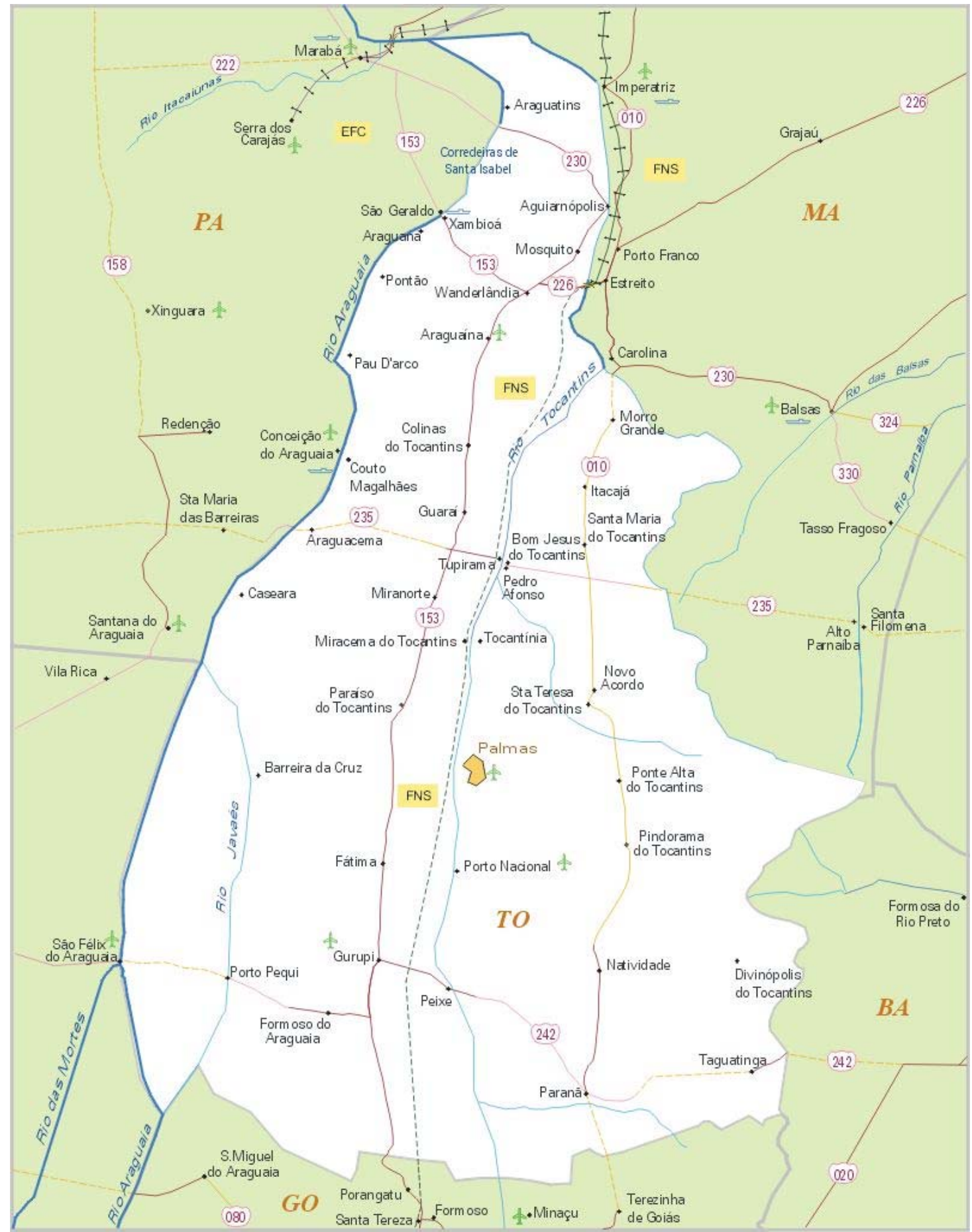

Figura 1 - Rede intermodal de transporte existente e planejada, Estado do Tocantins, Brasil, 1999

Fonte: Brasil (2003b) 


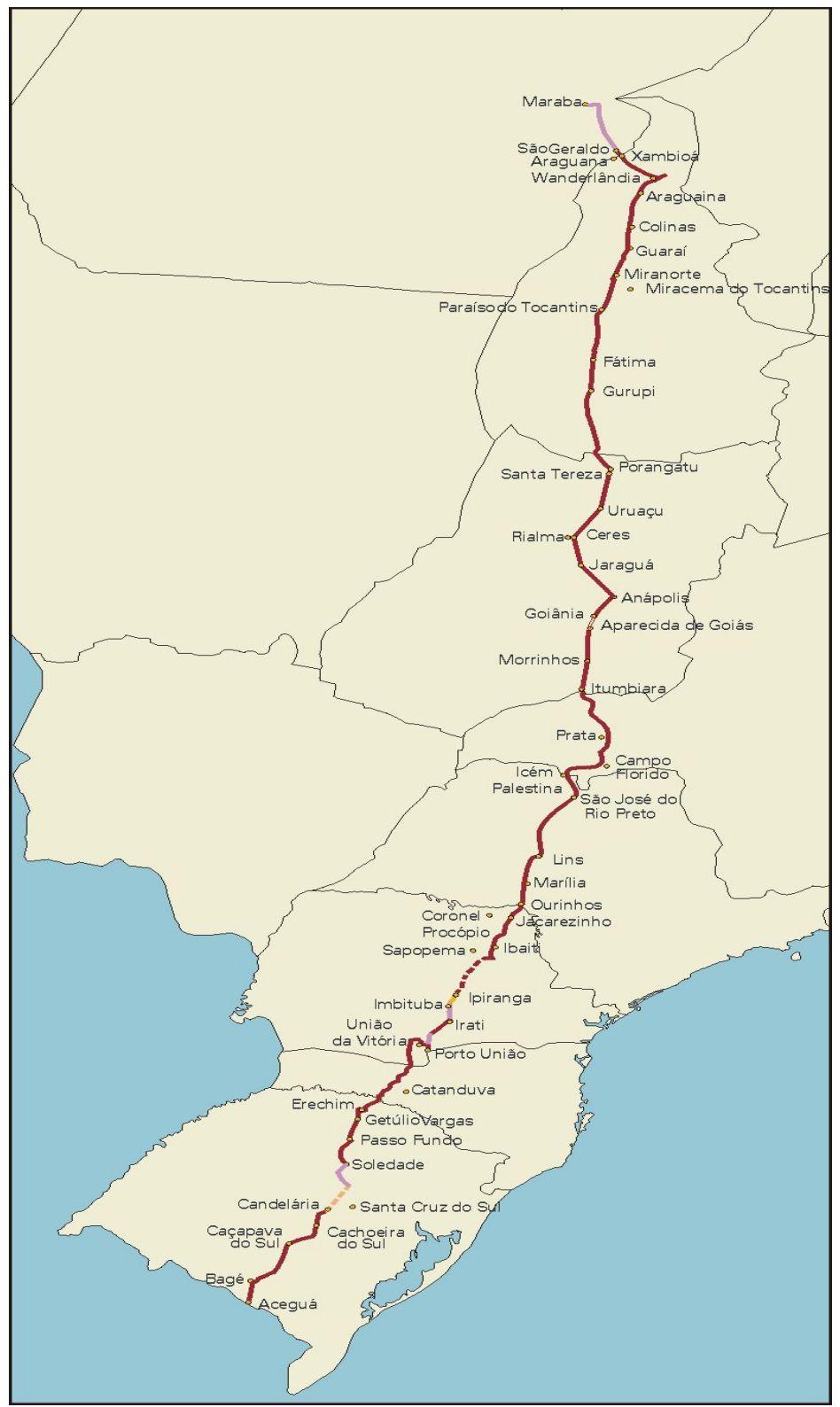

Figura 2 - Traçado da rodovia BR 153, Brasil, 2003 Fonte: Brasil (2003b)

De acordo com Tocantins (2002), a malha rodoviária total do Tocantins apresenta uma extensão de $27.140 \mathrm{~km}$. Desse total, $1.730 \mathrm{~km}$ são federais, 9.611 km são estaduais e 15.799 km são municipais. O Estado conta 
com $972 \mathrm{~km}$ de rodovias federais pavimentadas, dos quais $720 \mathrm{~km}$ correspondem à BR-153, principal elo de ligação entre o sul e o norte do Brasil. As rodovias estaduais e municipais constituem a maior parte da rede viária, somando $25.410 \mathrm{~km}$, dos quais apenas $2.770 \mathrm{~km}$ estavam pavimentados em 1999. A Tabela 1 apresenta a distribuição da malha viária estadual disponível em 1999, segundo a esfera administrativa responsável. Conforme Tocantins (2002), essa estrutura rodoviária é, ainda, insuficiente para atender à extensão territorial do Tocantins.

Tabela 1. Distribuição da malha viária do Estado do Tocantins, segundo a esfera administrativa responsável, em quilômetros, 1999

\begin{tabular}{lrrrrr}
\hline $\begin{array}{l}\text { Jurisdição/ } \\
\text { Situação }\end{array}$ & $\begin{array}{r}\text { Federal } \\
\left(\mathrm{DNER}^{1}\right)\end{array}$ & Estadual & $\begin{array}{c}\text { Estadual } \\
\text { Transitórias }\end{array}$ & Municipal & Total \\
\hline $\begin{array}{l}\text { Pavimentada } \\
\text { Não }\end{array}$ & 971,6 & $2.121,2$ & 174,7 & - & $3.267,5$ \\
pavimentada & 702,7 & $5.970,2$ & 109,5 & $15.799,0$ & $22.581,4$ \\
Em & 55,7 & $1.072,2$ & 163,5 & - & $1.291,4$ \\
pavimentação & $1.730,0$ & $9.163,6$ & 447,7 & $15.799,0$ & $27.140,3$ \\
Sub-total & 56,6 & - & - & - & 56,6 \\
Em implantação & 475,6 & $2.023,9$ & - & $6.835,0$ & $9.334,5$ \\
Planejada & $2.262,2$ & $11.187,5$ & 447,7 & $22.634,0$ & $36.531,4$ \\
Total & & & & & \\
\hline
\end{tabular}

Fonte: DEPARTAMENTO NACIONAL DE ESTRADAS DE RODAGEM (DNER) (1999)

${ }^{1}$ O DNER foi extinto pelo Decreto 4.128 de 13/02/2003 e suas atribuições foram repassadas para o Departamento Nacional de Infra-estrutura de Transporte (DNIT) e para a Agência Nacional de Transportes Terrestres (ANTT)

${ }^{2}$ Rodovias Estaduais Transitórias: rodovias estaduais existentes, listadas e codificadas como BRs, cujos traçados coincidem com diretrizes de rodovias federais planejadas, relacionadas na Rede Rodoviária do PNV 
Em se tratando de navegação interior, o Estado depende da consolidação da Hidrovia Tocantins-Araguaia, utilizando os rios Araguaia e Tocantins. Essa hidrovia é importante para a captação de insumos e para o escoamento dos produtos agrícolas tocantinenses e dos demais estados que ela tange. Por se tratar do objeto principal deste estudo, a Hidrovia TocantinsAraguaia receberá o devido destaque em momento posterior.

No que se refere à malha ferroviária, ainda que no momento esteja ausente, ela é de fundamental importância para a consolidação do projeto de transporte intermodal que os agentes econômicos públicos e privados locais idealizam para o Estado. Assim, a construção da Ferrovia Norte-Sul ganha relevância por complementar a infra-estrutura multimodal tocantinense, possibilitando, no sentido norte, a ligação com a Ferrovia Carajás e com o Porto de Itaqui, no Maranhão, favorecendo a comunicação com mercados exteriores. No sentido sul, a Ferrovia Norte-Sul possibilitará a comunicação com mercados domésticos através do sistema ferroviário do Centro-Sul. O traçado da NorteSul, ilustrado na Figura 3, localiza-se entre a BR-153 e o Rio Tocantins. 


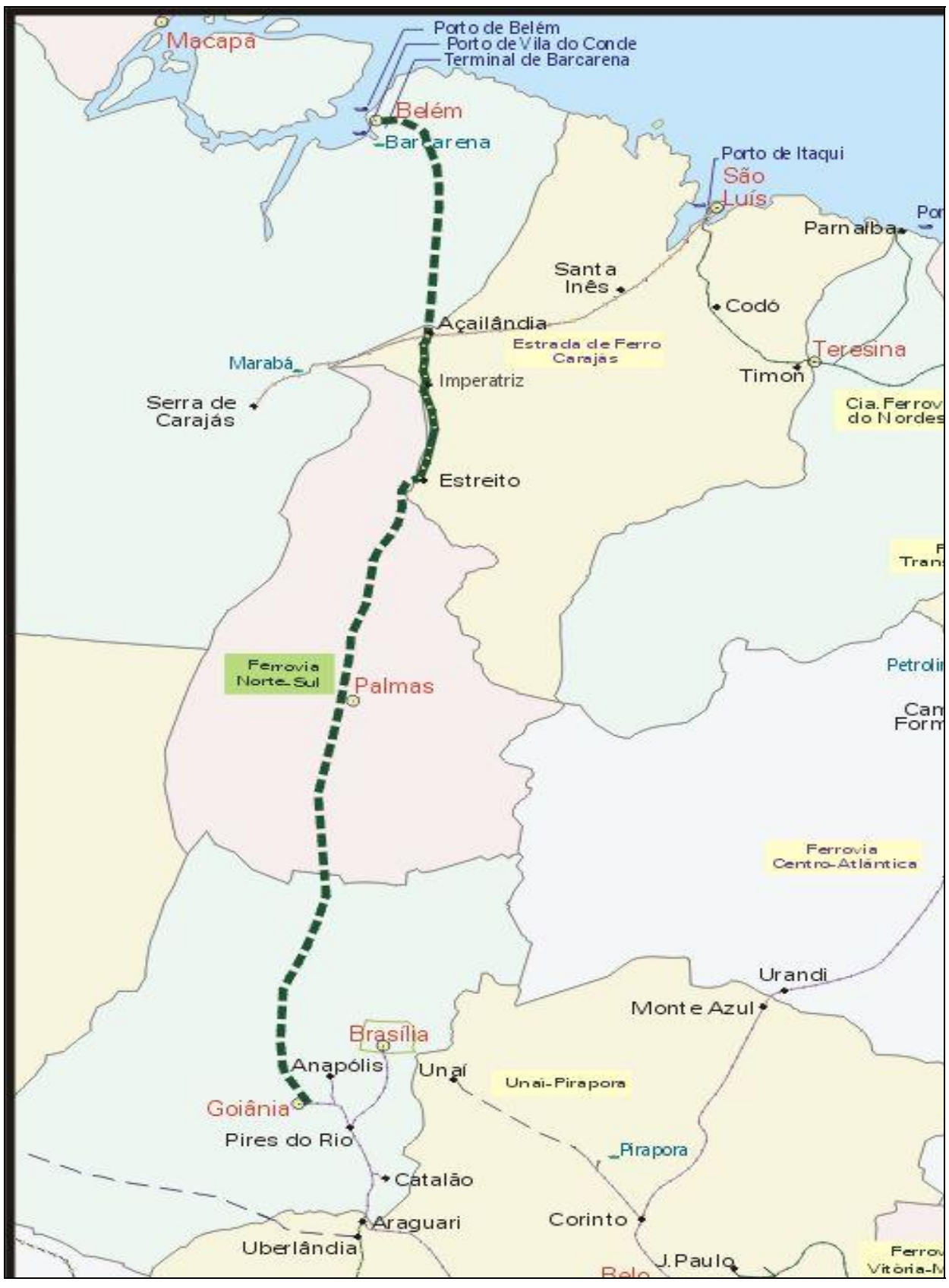

Figura 3 - Traçado projetado para a Ferrovia Norte-Sul, Brasil, 1999 Fonte: Brasil (2003b) 
Fica evidenciado que o estabelecimento de uma infra-estrutura pública de transporte adequada pode beneficiar, pelo acesso aos portos da Região Norte, não apenas o Estado do Tocantins mas, também, os circunvizinhos e os mais distantes, localizados no centro-sul brasileiro. Contudo, a implantação dessa infra-estrutura implica impactos econômicos, sociais e ambientais locais que precisam ser conhecidos e administrados. Isso exige a realização de estudos e a aplicação de métodos de avaliação que captem, preferencialmente em condições ex-ante, a intensidade e as conseqüências diretas e indiretas desses impactos. Além disso, é necessário conhecer as impressões dos idealizadores e dos usuários e/ou beneficiários potenciais da infra-estrutura, de modo a consolidar uma avaliação mais ampla e que atenda, dentro das possibilidades técnicas, aos interesses de todos.

\subsection{Hidrovia Tocantins-Araguaia: identificação e caracterização}

Hidrovia pode ser entendida como uma via navegável por onde circulam barcos, utilizando rios para estabelecer as rotas. Projetos de hidrovias consideram condições de navegação, segurança e garantia de tráfego, se possível o ano inteiro, na época da cheia e da seca. Essa via navegável é uma faixa imaginária sobre o rio, que não existe fisicamente, mas que consta das cartas e mapas náuticos que as embarcações, conseguem obedecer com precisão, orientadas pelas bóias e placas de sinalização.

De acordo com Tocantins (2002), a modalidade hidroviária de transporte é importante para a captação de insumos e para o escoamento dos produtos agrícolas tocantinenses e dos demais estados que ela tange. Isso está evidenciado no Programa do Governo Federal denominado "Brasil em Ação", onde a consolidação do Corredor de Transporte Multimodal Centro-Norte, 
baseia-se no aproveitamento potencial da Hidrovia Tocantins-Araguaia ${ }^{8}$. Esse projeto objetiva a implantação de um eixo de desenvolvimento de transporte hidro-rodo-ferroviário, que liga o planalto central aos portos da baía de São Marcos, no Maranhão e do rio Pará, no Pará.

O projeto da Hidrovia Tocantins-Araguaia data da década de 60, tendo sido retomado a partir dos anos 80, com o objetivo de implementar a navegação comercial na bacia Tocantins-Araguaia, em trechos já navegáveis durante boa parte do ano. AHITAR (1999) defende que essa perenização, mediante intervenções localizadas, como dragagem e/ou derrocamento ${ }^{9}$, sinalizações e balizamentos, tornam possível a utilização dos rios Tocantins e Araguaia como vias permanentemente navegáveis que podem atender às cargas agrícolas provenientes das safras de grãos das regiões Norte e CentroOeste.

A Hidrovia Tocantins-Araguaia projetada é constituída pelos rios das Mortes, Araguaia e Tocantins. No rio das Mortes, ela abrange 551 km entre Nova Xavantina (MT) e sua foz no rio Araguaia. No rio Araguaia, ela compreende cerca de 1.230 km, entre Aruanã (GO) e Xambioá (TO). No rio Tocantins, associam-se 420 km entre Palmas (TO) e Estreito (MA). Juntos, esses trechos significam cerca de $2.200 \mathrm{~km}$ de um canal navegável que, concluído, atenderá aos estados de Goiás, Tocantins, Pará e Maranhão. Segundo Tocantins (2002), essa alternativa para o transporte de grãos do cerrado oriental reduz cerca de 5.000 km da distância Brasil-Europa (Porto de Roterdan) e Brasil-Japão (via Canal do Panamá).

\footnotetext{
${ }^{8}$ Brasil (2003d) define transporte multimodal como aquele que utiliza duas ou mais modalidades de transporte, desde a origem até o destino, sob um único contrato entre as partes e responsabilidade do Operador de Transporte Multimodal.

${ }^{9}$ Dragagem é a limpeza do fundo do rio com o objetivo de garantir uma profundidade mínima para que as embarcações possam circular sem agarrar no fundo do canal. Derrocamento é a retirada de rochas do canal natural do rio que possam dificultar a navegação e provocar acidentes.
} 
A implantação da Hidrovia Tocantins-Araguaia está sob responsabilidade da Companhia Docas do Pará (CDP), uma sociedade de economia mista federal vinculada ao Ministério dos Transportes. A CDP, por sua vez, é representada pela AHITAR, uma superintendência que atua como órgão de execução, fiscalização e representação do Departamento de Hidrovias Interiores (DHI), da Secretaria de Transportes Aquaviários do Ministério dos Transportes. A jurisdição da AHITAR estende-se por uma área aproximada de $935.000 \mathrm{~km}^{2}$, abrangendo os estados de Mato Grosso, Goiás, Pará, Tocantins e Maranhão.

AHITAR (1999) afirma que a Hidrovia Tocantins-Araguaia faz parte de um projeto maior que pretende oferecer flexibilidade à navegação interior no Brasil, ao promover a integração entre as bacias do Paraguai, do Tocantins e do Amazonas, por intermédio dos rios Araguaia, Tocantins, São Francisco, Paraná, Guaporé e Madeira. Segundo Tocantins (2002) o valor global do empreendimento referente à Hidrovia Tocantins-Araguaia é estimado em $\mathrm{R} \$$ 222,4 milhões, distribuídos conforme indica a Tabela 2.

Tabela 2. Previsão de inversão de recursos na implantação da Hidrovia Tocantins-Araguaia, segundo o tipo de investimento

\begin{tabular}{|c|c|c|c|}
\hline Discriminação & Meta & Agentes & $\begin{array}{c}\text { Valor } \\
\text { (R\$ milhões) }\end{array}$ \\
\hline Hidrovia (1ªetapa) & $\begin{array}{l}\text { Construção hidrovias das } \\
\text { Mortes, Araguaia e Tocantins } \\
(2.230 \mathrm{~km})\end{array}$ & AHITAR/MT & 114,4 \\
\hline $\begin{array}{l}\text { Pavimentação da } \\
\text { Rodovia BR-153 }\end{array}$ & $\begin{array}{l}\text { Trecho Marabá - S. Geraldo } \\
\text { do Araguaia (150km) }\end{array}$ & DNER/MT & 40,0 \\
\hline Ferrovia Norte - Sul & $\begin{array}{l}\text { Ligação Imperatriz - Estreito, } \\
\text { Maranhão (120km) }\end{array}$ & VALEC/MT & 68,0 \\
\hline Total & & & 222,4 \\
\hline
\end{tabular}

Fonte: Tocantins (2002) 


\subsubsection{Características físicas e técnicas}

Segundo Brasil (2003a), a Hidrovia Tocantins-Araguaia está inserida na Bacia do Tocantins-Araguaia, cuja área é de 967.059 km² (11\% do território nacional) abrangendo os Estados de Goiás, Mato Grosso, Pará, Maranhão e Tocantins e o Distrito Federal, conforme ilustra a Figura 4. Conforme AHITAR (1999), a Hidrovia Tocantins-Araguaia, em toda a sua extensão, compreende áreas localizadas entre os paralelos $4^{\circ}$ e $18^{\circ}$ Sul e meridianos 46 e $55^{\circ}$ Oeste. Geograficamente limita-se ao sul pelo Planalto Central, a oeste pela Serra dos Carajás, a leste pela Serra Geral de Goiás e ao norte pelo estuário do rio Amazonas. 


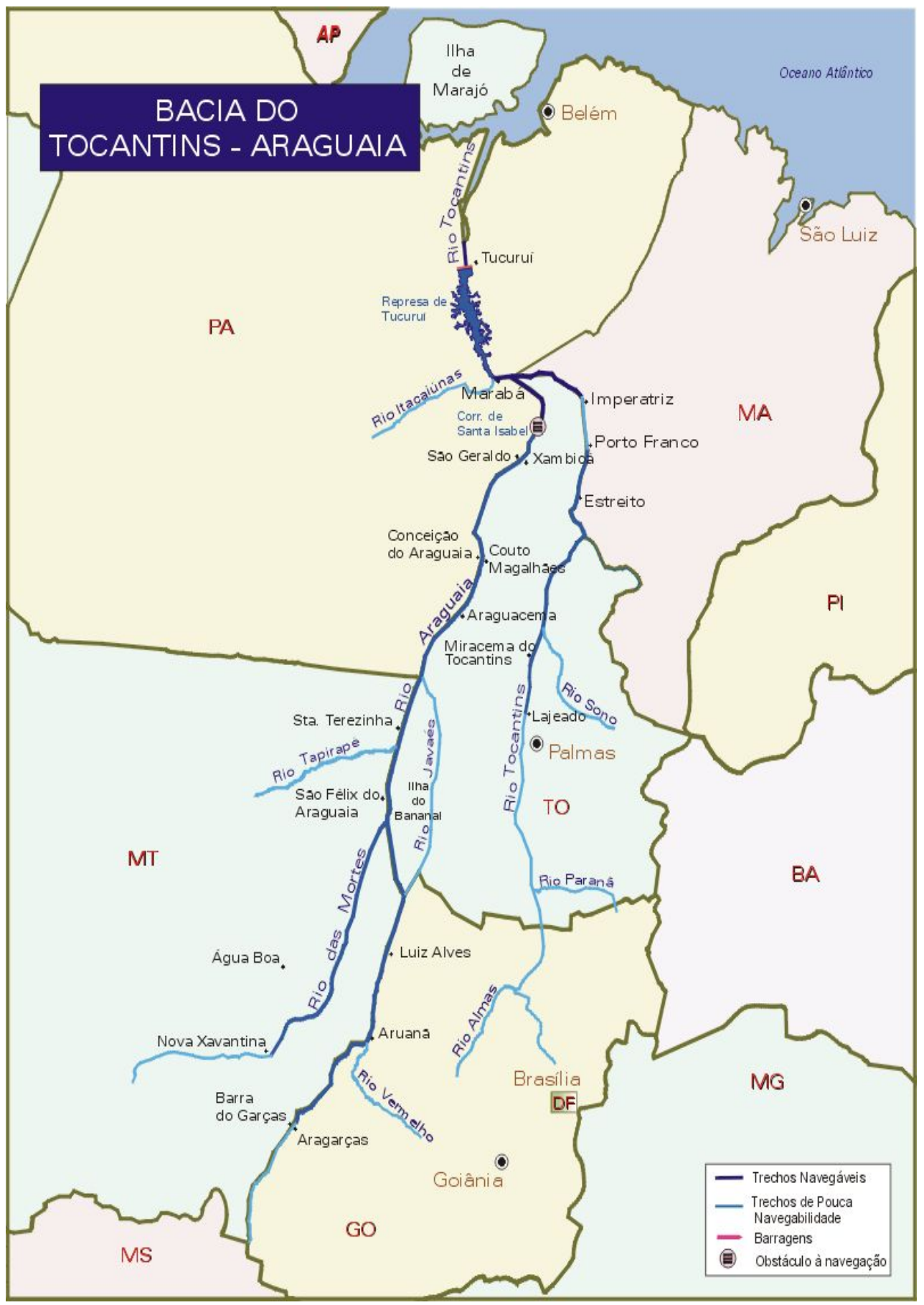

Figura 4 - Bacia do Tocantins-Araguaia, Brasil

Fonte: Brasil (2003b) 
A Hidrovia Tocantins-Araguaia é composta por três hidrovias particulares: das Mortes, Araguaia e Tocantins. A Hidrovia das Mortes está estruturada sobre o rio das Mortes, cuja nascente está em Cuiabá (MT) e a foz na Ilha do Bananal, depois de percorrer uma extensão de $1.070 \mathrm{~km}$. Nele, predomina o padrão de canal único que transborda na época das cheias, devido à amplitude lateral de sua planície de inundação, que se alarga em direção à foz, formando lagos e lagoas. Essa hidrovia tem regime hidrológico de águas baixas entre os meses de junho e novembro e de águas altas entre dezembro e maio, permitindo a navegação apenas por seis meses devido aos impedimentos físicos (bancos de areia e pedrais).

A Hidrovia Araguaia está sobre o rio Araguaia cuja nascente encontra-se na Serra dos Caiapós, na divisa de Goiás com Mato Grosso. Esse rio, após percorrer 720 km, envolve a ilha do Bananal, numa extensão de 375 km, e desemboca na margem esquerda do rio Tocantins, na divisa dos estados do Tocantins, Pará e Maranhão, drenando uma área de 365 mil km², num percurso de $2.115 \mathrm{~km}$. Nele, as altitudes variam, em média, de 850 metros, nas nascentes, até cerca de 100 metros, na sua foz, com uma declividade de 570m até a ilha do Bananal. Essa Hidrovia tem um regime hidrológico de águas baixas entre junho e novembro e de águas altas entre dezembro e maio. Ela apresenta restrições à navegação pela existência de pedrais e bancos de areia que restringem a navegação a comboios com 1,5 metro de calado.

A Hidrovia Tocantins situa-se sobre o rio Tocantins, cuja origem são os rios Almas e Maranhão, no interior do Distrito Federal, no Planalto de Goiás. Da origem ate a foz, na Baía de Marajó, próxima a Belém do Pará, o Tocantins percorre cerca de $2.000 \mathrm{~km}$. Suas altitudes variam de 1.000 metros, nas nascentes, a 100 metros na foz, predominando altitudes entre 500 e 200 metros, na maior parte de sua extensão. Suas águas destinam-se, principalmente, ao abastecimento público e à geração de energia elétrica, destacando-se as usinas hidrelétricas já existentes de Serra da Mesa e Cana 
Brava em Goiás, Luís Eduardo Magalhães (Lajeado) no Tocantins e Tucuruí, no Pará. A navegação no Tocantins pode ocorrer o ano todo, desde que as eclusas previstas sejam construídas. Como exemplo, a navegação poderá alcançar o município tocantinense de Peixe, desde que a barragem da Usina Hidrelétrica Luiz Eduardo Magalhães, construída no Município de Lajeado, entre as cidades de Palmas e Miracema do Tocantins, tenha eclusa para viabilizar a continuidade da navegação.

Considerando as características particulares a cada um de seus componentes, segundo Brasil (2003a), a Hidrovia Tocantins-Araguaia vem sendo preparada, de modo geral, para operar comboios de empurra compostos de quatro chatas e um empurrador. Cada comboio deve ter $108 \mathrm{~m}$ de comprimento, $16 \mathrm{~m}$ de largura e calado de 1,5 m, no máximo. Uma vantagem é a conexão com o Porto de Itaqui, em Ponta da Madeira (MA), único da costa brasileira que permite a atracação de navios com capacidade acima de 300 mil toneladas.

Uma estrutura fundamental para o adequado funcionamento da Hidrovia é o Porto de Xambioá, no rio Araguaia, cuja finalidade é integrar o modal hidroviário ao rodoviário, utilizando investimentos privados que atendam ao transporte de soja no corredor Tocantins-Araguaia. O porto dista $500 \mathrm{~km}$ de Palmas, capital do Estado pela rodovia BR-153, que também o interliga à Ferrovia Carajás na cidade de Marabá (PA) ou à Ferrovia Norte-Sul no Estreito (MA). Em termos de acesso hidroviário, o Porto de Xambioá pode ser alcançado através do rio Araguaia, durante o período de águas altas, quando se torna possível a ligação hidroviária entre Xambioá (TO) e Aruanã (GO). Sua área de influência abrange as regiões norte do Tocantins e leste do Pará. É considerado um importante ponto de entroncamento intermodal. Além disso, segundo Brasil (2003a), dispõe de cais com acostamento para comboios de até $120 \mathrm{~m}$ de comprimento e $2 \mathrm{~m}$ de profundidade. Possui armazém graneleiro com capacidade de 3.000 t e movimentação de grãos feita diretamente dos 
caminhões por sugador com capacidade de 90 toneladas/hora. Na realidade, essa estrutura está deteriorada e não tem condições de uso, conforme verificação in loco feita quando do trabalho de campo realizado neste estudo e apresentado em momento posterior.

\subsubsection{Características econômicas}

Ainda que seja assinalado um potencial econômico significativo para a navegação interior no Brasil, as deficiências na implantação ou na operação das hidrovias, devido ao aporte inadequado de recursos para investimentos e/ou manutenção, têm prejudicado a realização desse potencial. Segundo a Confederação Nacional dos Transportes (CNT) (2002a), o reduzido desenvolvimento da navegação interior se deve à baixa prioridade dos investimentos governamentais no setor, comprometendo a viabilidade econômica dos projetos. Além disso, a utilização deficiente resulta da baixa quantidade e qualidade dos terminais intermodais instalados nos rios, o que inibe a demanda pelo transporte hidroviário, principalmente no Brasil, onde as vias navegáveis, geralmente, estão distantes dos pólos produtores. Além disso, é preciso resolver os conflitos relacionados ao uso múltiplo da água, principalmente no que diz respeito à navegação interior e à geração de energia hidrelétrica. É fundamental garantir as condições de navegação dos comboios e a transposição das barragens através de eclusas ou canais, criando condições propícias ao investimento privado, ao crescimento econômico e ao desenvolvimento regional.

Outro aspecto inibidor dos investimentos em hidrovias no País é a tendência de priorização do modal rodoviário. Porém, com isso, o Brasil deixa de exercer seu potencial de transporte hidroviário de grandes volumes de carga originada nas regiões interiores a um baixo custo unitário de transporte, bem como de favorecer a entrada de áreas que estejam mais distantes dos eixos 
rodoviários. AHITAR (1999) assinala que a abertura dos grandes eixos rodoviários interioranos fez com que os municípios pioneiros, que brotaram ao longo das vias navegáveis, tivessem sua vocação econômica relegada ao abandono, com o fluxo migratório dirigindo-se para as áreas sob influência das rodovias. Diante disso, afirma o autor, estruturar e perenizar algumas hidrovias pode significar a reabertura econômica dessas comunidades, oferecendo-lhes oportunidade de incorporar novas áreas agrícolas e de recuperar outras que estejam degradadas. No caso da implantação da Hidrovia Tocantins-Araguaia, espera-se uma redução de $45 \%$ no custo do frete, no curto prazo, e de $60 \%$ no médio prazo. Além disso, a Hidrovia deve estimular a incorporação de aproximadamente 30 milhões de hectares ao sistema produtivo, com um potencial gerador de 73 milhões de toneladas de grãos, principalmente soja, milho e arroz. Deve-se destacar que a pretensão é transportar, além de grãos para exportação, insumos agrícolas, calcáreo, combustíveis, gado, madeira dentre outros produtos. Outra possibilidade é a exploração de atividades de turismo e de lazer regional.

Dentre os projetos regionais de desenvolvimento, carentes de infraestrutura hidroviária, está o da Zona de Frente de Expansão Centro-Norte. Esse projeto engloba o cerrado brasileiro, pólo dinâmico da atividade agro-industrial, cujas vantagens de clima, topografia e solo, possibilitam uma agricultura extensiva e de alta produtividade. Contudo, essa região defronta-se, principalmente, com um modal rodoviário de transporte direcionado ao sul do País, incorrendo em maior distância e em estrutura portuária sobrecarregada, como se assiste, anualmente, no Porto de Paranaguá, no Paraná na safra da soja. Brasil (2003a) assinala que a navegação fluvial, principalmente no Araguaia, tem potencial para o escoamento de 3 milhões de toneladas de soja da região Centro-Oeste. Além disso, a região possui cerca de 300 espécies de peixes e um expressivo potencial turístico relacionado à pesca, configurando uma possibilidade de desenvolvimento econômico sustentável para a região. A 
implantação de infra-estrutura básica, como terminais hidroviários e orlas urbanizadas, pode fomentar o setor de construção civil. Os lagos das hidrelétricas de Tucuruí, Serra da Mesa e Luís Eduardo Magalhães (Lajeado) podem também servir à exploração turística. A Figura 5 reúne as diferentes opções de exploração econômica possíveis para a Bacia Tocantins-Araguaia. Com relação ao processo de implantação da Hidrovia Tocantins-Araguaia, existem registros na literatura que dão conta de seu andamento. CNT (2002b) observa que, apesar da hidrovia não estar operando de forma comercial, investimentos privados têm sido direcionados para a implantação de terminais hidroviários, acompanhados de investimentos públicos, estaduais e federais, na construção de plataformas multimodais. Como exemplos, destacam-se os terminais de Água Boa (MT), Xambioá e Couto Magalhães (TO) implantados, respectivamente, pelas empresas privadas NAVBEL em 1997, Cia Vale do Rio Doce em 1996 e Araguaiana em 1999/2000. Além desses, registra-se a Plataforma Rodo-Ferroviária de Porto Franco (MA) construída pelo Ministério dos Transportes e a Plataforma Multimodal de Aguiarnópolis (TO) em construção pelos governos federal e estadual e pela Federação das Indústrias do Estado do Tocantins (FIETO). Lima (2000) registra entrevista do coordenador do projeto, José Roberto Fernandes, que afirma a possibilidade de Aguiarnópolis tornar-se um pólo concentrador, transformador e exportador de produtos, devido à proximidade do planejado entroncamento multimodal de transporte rodoviário, ferroviário e hidroviário. Segundo Fernandes, acontecerá uma diversificação das formas de produção como produção de papel e celulose, esmagamento de soja, abate de aves, processamento de frutas, fabricação de rações para produção avícola local, uso de babaçu como forma energética, dentre outras. A Plataforma de Aguiarnópolis tem como base o rio Tocantins, como se observa na Figura 6. 


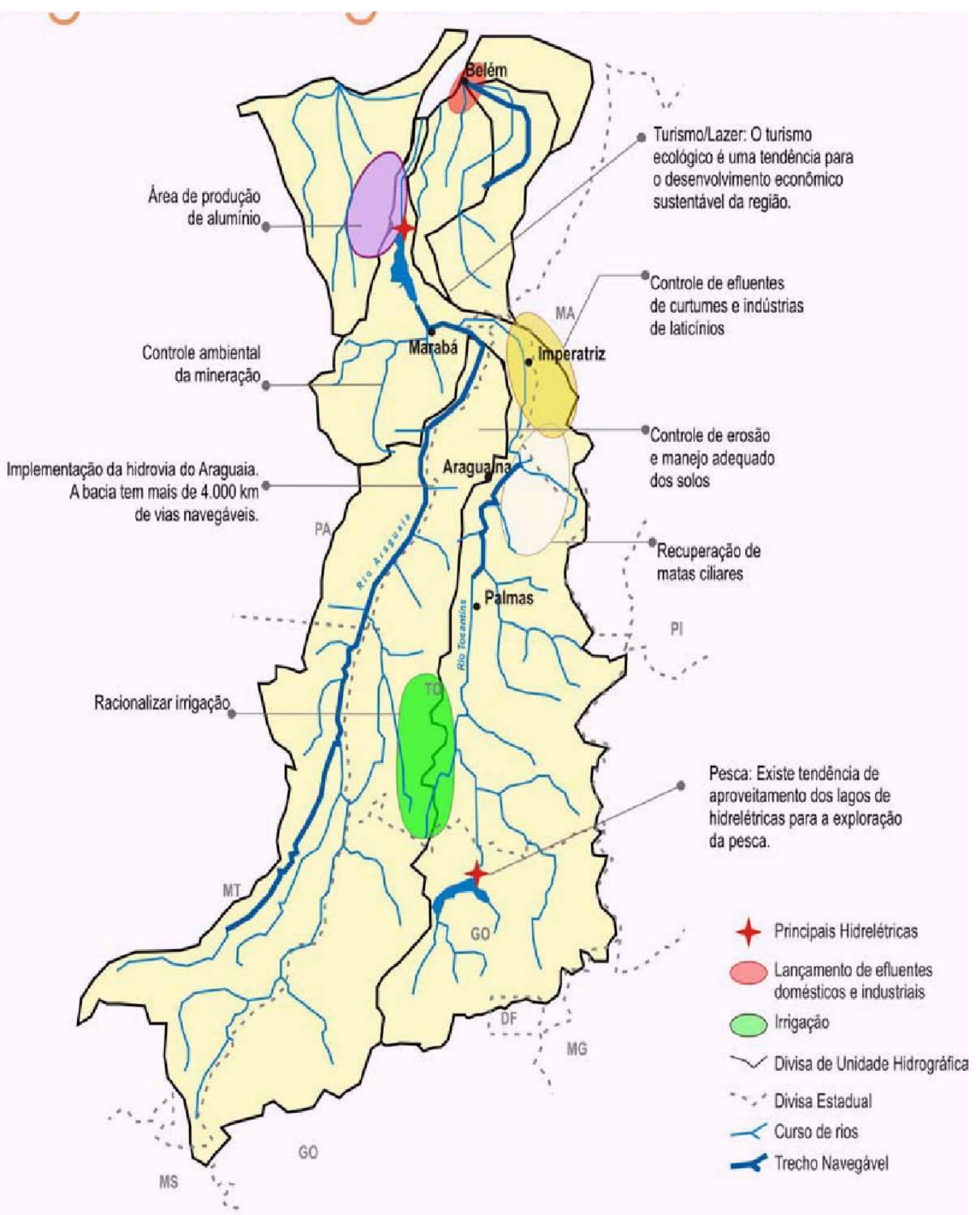

Figura 5 - Opções econômicas na exploração da Bacia Tocantins-Araguaia, Brasil

Fonte: Brasil (2003a) 


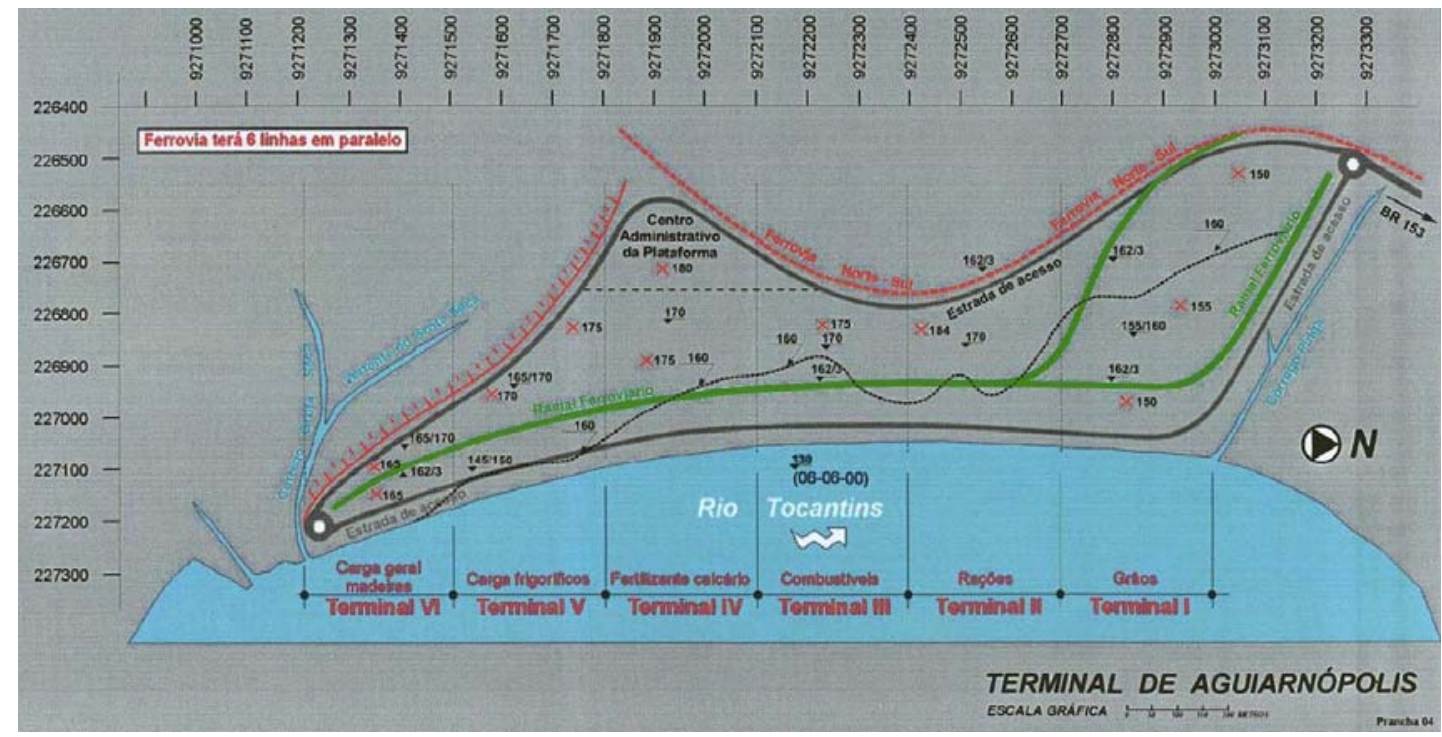

Figura 6 - Plataforma multimodal de Aguiarnópolis, Estado do Tocantins Fonte: Fieto (2000)

Uma vez que o potencial econômico da Hidrovia Tocantins-Araguaia está relacionado à sua utilização na movimentação de cargas torna-se interessante observar a evolução dessa operação em período recente (19982000). Vale notar que, desde então, nenhuma outra viagem foi realizada na hidrovia, o que poderia classificar as viagens como experimentais. A Tabela 3 apresenta as estatísticas referentes à movimentação de carga nas principais hidrovias brasileiras, entre 1998 e 2000, incluindo a Tocantins-Araguaia. Como se pode ver, essa hidrovia, em suas viagens experimentais, movimentou pequena quantidade de carga, quando comparada às demais hidrovias e ao complexo hidroviário como um todo. As 2.400 toneladas, nos anos de 1998, 1999 e 2000, corresponderam à apenas 0,01\% do total de cargas movimentado por todas as hidrovias. Ao analisar a movimentação de carga na Hidrovia Tocantins-Araguaia, apresentada na Tabela 4, observa-se que, entre 1998 e 2000, as cargas originaram-se em Água Boa (MT) e Couto Magalhães (TO), diferenciando-se entre soja, calcáreo e brita. Enquanto a soja, em 1998, 
destinou-se à Xambioá (TO), em 1999 e 2000, calcáreo e brita foram em direção ao Mato Grosso. Assim, a hidrovia cumpriu seu papel básico de transportar insumos para as áreas de produção e produtos acabados para as áreas de consumo no País. 
Tabela 3. Movimentação geral de cargas nas principais hidrovias, Brasil, 19982000 (em toneladas)

\begin{tabular}{|c|c|c|c|c|c|c|}
\hline Hidrovia & 1998 & 1999 & 2000 & $\begin{array}{c}\text { Variação } \\
\text { 98-99 } \\
\end{array}$ & $\begin{array}{l}\text { Variação } \\
99-2000 \\
\end{array}$ & $\begin{array}{l}\text { Variação } \\
98-2000 \\
\end{array}$ \\
\hline \multicolumn{7}{|c|}{ Bacia Amazônica Amazônia Ocidental } \\
\hline Madeira & 1.454 .716 & 1.418 .069 & 1.955 .471 & $-2,52 \%$ & $37,90 \%$ & $34,42 \%$ \\
\hline Solimões & 1.581 .940 & 1.629 .555 & 2.291 .165 & $3,01 \%$ & $40,60 \%$ & $44,83 \%$ \\
\hline \multicolumn{7}{|c|}{ Bacia Amazônica Amazônia Oriental } \\
\hline Amazonas & 13.075 .812 & 14.839 .447 & 12.997 .779 & $13,49 \%$ & $-12,41 \%$ & $-0,60 \%$ \\
\hline $\begin{array}{l}\text { Guamá } \\
\text { Capim }\end{array}$ & 318.263 & 539.984 & 720.751 & $69,67 \%$ & $33,48 \%$ & $126,46 \%$ \\
\hline \multicolumn{7}{|c|}{ Bacia do Nordeste } \\
\hline Parnaíba & - & - & 45.169 & - & - & - \\
\hline $\begin{array}{l}\text { Rios } \\
\text { Estaduais }\end{array}$ & - & - & 142.011 & - & - & - \\
\hline \multicolumn{7}{|c|}{ Bacia do São Francisco } \\
\hline $\begin{array}{l}\text { São } \\
\text { Francisco } \\
\text { Grande }\end{array}$ & 47.238 & 65.610 & 58.766 & $38,89 \%$ & $-10,43 \%$ & $24,40 \%$ \\
\hline \multicolumn{7}{|c|}{ Bacia do Tocantins-Araguaia } \\
\hline $\begin{array}{l}\text { Araguaia } \\
\text { Mortes } \\
\text { Tocantins }\end{array}$ & 2.400 & 2.400 & 2.400 & 0 & 0 & 0 \\
\hline \multicolumn{7}{|c|}{ Bacia do Paraguai } \\
\hline Paraguai & 2.155 .574 & 2.053 .449 & 1.911 .326 & $-4,74 \%$ & $-6,92 \%$ & $-11,33 \%$ \\
\hline \multicolumn{7}{|c|}{ Bacia do Tietê-Paraná } \\
\hline $\begin{array}{l}\text { Tietê } \\
\text { Paraná }\end{array}$ & 1.722 .677 & 1.740 .159 & 1.531 .920 & $1,01 \%$ & $-11,97 \%$ & $-11,07 \%$ \\
\hline \multicolumn{7}{|c|}{$\begin{array}{l}\text { Bacia do Sudeste } \\
\text { Jacuí }\end{array}$} \\
\hline $\begin{array}{l}\text { Taquari L. } \\
\text { dos Patos }\end{array}$ & 544.663 & 503.418 & 407.139 & $-7,57 \%$ & $-19,13 \%$ & $-25,25 \%$ \\
\hline Total & 20.903 .283 & 22.792 .091 & 22.063 .897 & $9,04 \%$ & $-3,19 \%$ & $5,55 \%$ \\
\hline
\end{tabular}

Fonte: Brasil (2003b) 
Tabela 4. Movimentação de cargas, Hidrovia Tocantins-Araguaia, Brasil, 19982000

\begin{tabular}{cccccc}
\hline $\begin{array}{c}\text { Terminal } \\
\text { Origem }\end{array}$ & $\begin{array}{c}\text { Terminal } \\
\text { Destino }\end{array}$ & $\begin{array}{c}\text { Distância } \\
(\mathrm{km})\end{array}$ & $\begin{array}{c}\text { Quantidade } \\
(\mathrm{t})\end{array}$ & $\begin{array}{c}\text { Produção } \\
\text { Transporte } \\
(\mathrm{tku})\end{array}$ & Produto \\
\hline
\end{tabular}

Período de Referência: Ano de 1998

Porto de

$\begin{array}{llllll}\text { Água Boa } & \begin{array}{l}\text { Xambioá } \\ \text { (TO) }\end{array} & 1.111 & 2.400 & 2.666 .400 & \text { Soja }\end{array}$ Navbel

(MT)

Período de Referência: Ano de 1999

Porto Couto São Félix

$\begin{array}{llllll}\text { Magalhães } & \begin{array}{l}\text { do } \\ \text { Araguaia }\end{array} & 456 & 2.400 & 1.094 .400 & \text { Calcário Araguaiana } \\ \text { (TO) } & \text { (MT) } & & & \end{array}$

Período de Referência: Ano de 2000

\begin{tabular}{llccccc} 
Porto Couto & $\begin{array}{l}\text { Luciara } \\
\text { Magalhães }\end{array}$ & 407 & 1.800 & 732.600 & Calcário & Araguaiana \\
$\begin{array}{l}\text { (TO) } \\
\text { Santa }\end{array}$ & $\begin{array}{l}\text { Terezinha } \\
\text { (MT) }\end{array}$ & 310 & 600 & 186.000 & Brita & Araguaiana \\
\hline
\end{tabular}

Fonte: Brasil (2003b)

Vale observar que na rede urbana dessa região hidrográfica observase a predominância expressiva de municípios com até 5.000 habitantes (54,3\% do total de centros urbanos), com apenas 13\% da população urbana regional. Entre as cidades principais destacam-se Imperatriz-MA (230 mil hab.), MarabáPA (168 mil hab), Palmas-TO (137 mil hab.) e Araguaína-TO (113 mil hab.). A maior parte da população concentra-se nas unidades hidrográficas do Tocantins e no litoral do Pará. A região hidrográfica possui 409 sedes municipais e 470 municípios nela inseridos total ou parcialmente. Algumas características 
demográficas, sociais e econômicas, relativas ao ano 2000, dos principais municípios abrangidos pela Hidrovia Tocantins-Araguaia estão apresentadas nas Tabelas 5 a 10.

Tabela 5. Características demográficas, sociais e econômicas dos principais municípios na área de influência da Hidrovia Tocantins-Araguaia, Estado de Goiás, Brasil, 2000

\begin{tabular}{|c|c|c|c|}
\hline Descrição & ARUANÃ & NOVA CRIXÁS & $\begin{array}{l}\text { S. MIGUEL DO } \\
\text { ARAGUAIA }\end{array}$ \\
\hline Área Total (km2) & 3050 & 7298 & 6145 \\
\hline \multicolumn{4}{|l|}{ População } \\
\hline Residentes & 5095 & 11061 & 22793 \\
\hline .homens & 2661 & 5883 & 11640 \\
\hline mulheres & 2434 & 5178 & 11153 \\
\hline \multicolumn{4}{|l|}{ Habitação } \\
\hline Domicílios & 1384 & 3010 & 6298 \\
\hline .esgoto sanitário & 4 & 7 & 16 \\
\hline água encanada & 717 & 1200 & 2998 \\
\hline lixo coletado & 860 & 1601 & 4907 \\
\hline \multicolumn{4}{|l|}{ Saúde } \\
\hline Hospitais & 1 & 2 & 3 \\
\hline Leitos hospital & 22 & 50 & 91 \\
\hline \multicolumn{4}{|l|}{ Ensino (estabelec.) } \\
\hline Fundamental & 4 & 18 & 21 \\
\hline Médio & 1 & 1 & 2 \\
\hline \multicolumn{4}{|l|}{ Economia } \\
\hline $\mathrm{FPM}(\mathrm{R} \$)$ & 1.103 .483 & 1.257 .733 & 2.305 .844 \\
\hline ITR (R\$) & 60.301 & 155.341 & 134.882 \\
\hline
\end{tabular}

Fonte: IBGE (2003) 
Tabela 6. Características demográficas, sociais e econômicas dos principais municípios na área de influência da Hidrovia Tocantins-Araguaia, Estado do Mato Grosso, Brasil, 2000

\begin{tabular}{|c|c|c|c|c|c|}
\hline Descrição & $\begin{array}{l}\text { COCA- } \\
\text { LINHO }\end{array}$ & $\begin{array}{l}\text { LUCl- } \\
\text { ÁRA }\end{array}$ & $\begin{array}{c}\text { NOVA } \\
\text { XAVAN- } \\
\text { TINA }\end{array}$ & $\begin{array}{l}\text { S. FÉLIX DO } \\
\text { ARAGUAIA }\end{array}$ & $\begin{array}{c}\text { STA. } \\
\text { TEREZINHA }\end{array}$ \\
\hline Área Total (km2) & 19414 & 4644 & 5743 & 18935 & 6451 \\
\hline \multicolumn{6}{|l|}{ População } \\
\hline Residentes & 5504 & 2494 & 17832 & 10687 & 6270 \\
\hline .homens & 2900 & 1298 & 9181 & 5619 & 3289 \\
\hline mulheres & 2604 & 1196 & 8651 & 5068 & 2981 \\
\hline \multicolumn{6}{|l|}{ Habitação } \\
\hline Domicílios & 1374 & 596 & 5060 & 2768 & 1430 \\
\hline .esgoto sanitário & 3 & 0 & 126 & 4 & 2 \\
\hline .água encanada & 431 & 401 & 3788 & 1019 & 517 \\
\hline .lixo coletado & 726 & 326 & 3675 & 1397 & 278 \\
\hline \multicolumn{6}{|l|}{ Saúde } \\
\hline Hospitais & 1 & 0 & 3 & 2 & 1 \\
\hline Leitos hospital & 16 & 0 & 77 & 44 & 23 \\
\hline \multicolumn{6}{|l|}{ Ensino (estabelec.) } \\
\hline Fundamental & 10 & 9 & 31 & 9 & 14 \\
\hline Médio & 1 & 1 & 3 & 2 & 2 \\
\hline \multicolumn{6}{|l|}{ Economia } \\
\hline $\mathrm{FPM}(\mathrm{R} \$)$ & 1.360 .031 & 1.360 .031 & 2.132 .509 & 1.683 .848 & 1.165 .741 \\
\hline ITR (R\$) & 116.236 & 33.280 & 68.962 & 129.403 & 56.315 \\
\hline
\end{tabular}

Fonte: IBGE (2003) 
Tabela 7. Características demográficas, sociais e econômicas dos principais municípios na área de influência da Hidrovia Tocantins-Araguaia, rio Araguaia, Estado do Tocantins, Brasil, 2000

\begin{tabular}{|c|c|c|c|c|c|}
\hline Descrição & $\begin{array}{l}\text { ARAGUA- } \\
\text { CEMA }\end{array}$ & $\begin{array}{l}\text { ARAGUA- } \\
\text { TINS }\end{array}$ & $\begin{array}{c}\text { CASEA- } \\
\text { RA }\end{array}$ & $\begin{array}{c}\text { COUTO DE } \\
\text { MAGALHÃES }\end{array}$ & XAMBIOÁ \\
\hline Área Total (km2) & 2778 & 2287 & 1692 & 1586 & 1382 \\
\hline \multicolumn{6}{|l|}{ População } \\
\hline Residentes & 5414 & 26010 & 3660 & 4335 & 12137 \\
\hline homens & 2804 & 13302 & 1893 & 2320 & 6142 \\
\hline mulheres & 2610 & 12708 & 1767 & 2015 & 5995 \\
\hline \multicolumn{6}{|l|}{ Habitação } \\
\hline Domicílios & 1308 & 5737 & 908 & 1080 & 2816 \\
\hline .esgoto sanitário & 2 & 3 & 2 & 0 & 1 \\
\hline .água encanada & 749 & 3236 & 501 & 490 & 1596 \\
\hline .lixo coletado & 463 & 2716 & 274 & 162 & 1500 \\
\hline \multicolumn{6}{|l|}{ Saúde } \\
\hline Hospitais & 1 & 2 & 1 & 1 & 1 \\
\hline Leitos hospital & 27 & 52 & 12 & 30 & 30 \\
\hline \multicolumn{6}{|l|}{ Ensino (estabelec.) } \\
\hline Fundamental & 13 & 56 & 10 & 21 & 23 \\
\hline Médio & 2 & 5 & 1 & 1 & 3 \\
\hline \multicolumn{6}{|l|}{ Economia } \\
\hline FPM (R\$) & 852.893 & 1.990 .083 & 852.893 & 852.893 & 1.394 .816 \\
\hline ITR $\quad(R \$)$ & 14.872 & 14.772 & 13.606 & 9.421 & 15.726 \\
\hline
\end{tabular}

Fonte: IBGE (2003) 
Tabela 8. Características demográficas, sociais e econômicas dos principais municípios na área de influência da Hidrovia Tocantins-Araguaia, rio Tocantins, Estado do Tocantins, Brasil, 2000

\begin{tabular}{lccccc}
\hline \multicolumn{1}{c}{ Descrição } & $\begin{array}{c}\text { MIRACEMA } \\
\text { DO TO }\end{array}$ & PALMAS & $\begin{array}{c}\text { PEDRO } \\
\text { AFONSO }\end{array}$ & PEIXE & $\begin{array}{c}\text { PORTO } \\
\text { NACIONAL }\end{array}$ \\
\hline Área Total (km2) & 2656 & 2465 & 2042 & 5091 & 4446 \\
População & & & & & \\
$\quad$ Residentes & 24444 & 137355 & 9028 & 8763 & 44991 \\
$\quad$.homens & 12978 & 68735 & 4619 & 4679 & 22479 \\
$\quad$ mulheres & 11466 & 68620 & 4409 & 4084 & 22512 \\
Habitação & & & & & \\
$\quad$ Domicílios & 5887 & 35047 & 2217 & 2357 & 10544 \\
$\quad$ esgoto sanitário & 19 & 5984 & 5 & 1 & 29 \\
.água encanada & 4724 & 32458 & 1818 & 1215 & 8375 \\
$\quad$.lixo coletado & 4032 & 32552 & 1585 & 428 & 7391 \\
Saúde & & & & & \\
$\quad$ Hospitais & 1 & 3 & 1 & 1 & 1 \\
Leitos hospital & 71 & 195 & 43 & 37 & 76 \\
Ensino (estabelec.) & & & & & \\
Fundamental & 37 & 59 & 23 & 13 & 78 \\
Médio & 3 & 20 & 3 & 1 & 11 \\
Economia & & & & & \\
FPM (R\$) & 1.502 .110 & 51.515 .967 & 965.642 & 1.287 .523 & 2.575 .045 \\
ITR (R\$) & 27.574 & 11.974 & 10.684 & 35.682 & 37.348 \\
\hline
\end{tabular}

Fonte: IBGE (2003) 
Tabela 9. Características demográficas, sociais e econômicas dos principais municípios na área de influência da Hidrovia Tocantins-Araguaia, Estado do Pará, Brasil, 2000

\begin{tabular}{|c|c|c|c|}
\hline Descrição & $\begin{array}{l}\text { CONCEIÇÃO DO } \\
\text { ARAGUAIA }\end{array}$ & MARABÁ & $\begin{array}{l}\text { S. GERALDO DO } \\
\text { ARAGUAIA }\end{array}$ \\
\hline Área Total (km2) & 5829 & 15092 & 3270 \\
\hline \multicolumn{4}{|l|}{ População } \\
\hline Residentes & 43386 & 168020 & 27646 \\
\hline homens & 22246 & 84709 & 14383 \\
\hline mulheres & 21140 & 83311 & 13263 \\
\hline \multicolumn{4}{|l|}{ Habitação } \\
\hline Domicílios & 10446 & 37919 & 6187 \\
\hline .esgoto sanitário & 31 & 386 & 2 \\
\hline .água encanada & 4909 & 13698 & 552 \\
\hline lixo coletado & 5788 & 21695 & 1108 \\
\hline \multicolumn{4}{|l|}{ Saúde } \\
\hline Hospitais & 6 & 4 & 2 \\
\hline Leitos hospital & 206 & 246 & 60 \\
\hline \multicolumn{4}{|l|}{ Ensino (estabelec.) } \\
\hline Fundamental & 100 & 285 & 129 \\
\hline Médio & 5 & 24 & 3 \\
\hline \multicolumn{4}{|l|}{ Economia } \\
\hline $\mathrm{FPM}(\mathrm{R} \$)$ & 4.058 .569 & 13.834 .652 & 2.683 .893 \\
\hline ITR (R\$) & 36.660 & 82.205 & 19.187 \\
\hline
\end{tabular}

Fonte: IBGE (2003) 
Tabela 10. Características demográficas, sociais e econômicas dos principais municípios na área de influência da Hidrovia Tocantins-Araguaia, Estado do Maranhão, Brasil, 2000

\begin{tabular}{|c|c|c|c|}
\hline Descrição & ESTREITO & IMPERATRIZ & PORTO FRANCO \\
\hline Área Total (km2) & 2716 & 1531 & 1416 \\
\hline \multicolumn{4}{|l|}{ População } \\
\hline Residentes & 22930 & 230566 & 16840 \\
\hline homens & 11599 & 110947 & 8432 \\
\hline mulheres & 11331 & 119619 & 8408 \\
\hline \multicolumn{4}{|l|}{ Habitação } \\
\hline Domicílios & 5180 & 54354 & 3852 \\
\hline .esgoto sanitário & 9 & 13437 & 2 \\
\hline .água encanada & 3715 & 48407 & 2770 \\
\hline .lixo coletado & 2839 & 46748 & 982 \\
\hline \multicolumn{4}{|l|}{ Saúde } \\
\hline Hospitais & 4 & 22 & 2 \\
\hline Leitos hospital & 82 & 2250 & 105 \\
\hline \multicolumn{4}{|l|}{ Ensino (estabelec.) } \\
\hline Fundamental & 82 & 214 & 53 \\
\hline Médio & 2 & 19 & 2 \\
\hline \multicolumn{4}{|l|}{ Economia } \\
\hline FPM (R\$) & 2.146 .586 & 15.628 .124 & 2.189 .105 \\
\hline ITR (R\$) & 10.532 & 19.672 & 11.465 \\
\hline
\end{tabular}

Fonte: IBGE (2003) 
O exame dessas tabelas permite estabelecer um comparativo entre os diferentes municípios relacionando aspectos sobre área, população, habitação, saúde, ensino e economia do setor público municipal. Segundo os dados econômicos, podem ser citados como mais expressivos os municípios de São Miguel do Araguaia em Goiás; Nova Xavantina e São Félix do Araguaia no Mato Grosso; Araguatins e Xambioá às margens do Rio Araguaia e Miracema do Tocantins, Palmas e Porto Nacional às margens do Rio Tocantins, no Tocantins; Marabá no Pará; e, Imperatriz no Maranhão. De modo geral, considera-se que a implantação e operação da Hidrovia Tocantins-Araguaia cause impactos sociais, econômicos e ambientais não desprezíveis sobre todas as localidades relacionadas. Sendo devidamente identificados os efeitos negativos e positivos e estabelecidas as medidas mitigadoras e compensatórias adequadas, a Hidrovia representaria uma alternativa de transporte interessante e potencial sob o ponto de vista municipal, estadual e regional.

\subsubsection{Impactos ambientais e socio-econômicos}

Implantar e operar uma hidrovia implica uma série de impactos positivos e negativos sobre o meio ambiente da sua área de influência. $A$ despeito de estarem associados ao processo de crescimento $\mathrm{e}$ desenvolvimento econômicos, os impactos positivos representam benefícios e os negativos custos que deveriam ser considerados na análise de viabilidade econômica da implantação e operação hidroviária. Uma vez que não estejam contemplados, distorcem as expectativas de retorno sobre o investimento considerado. Dentre os impactos negativos Bucher \& Huszar (1995) destacam:

a) aumento do risco de erosão e de assoreamento dos rios e canais, causando perda de qualidade da água e da biodiversidade, principalmente de espécies de peixes; 
b) poluição por defensivos, resíduos urbanos, industriais ou de extração mineral, bem como por óleo combustível oriundo das próprias embarcações;

c) fortes mudanças no cenário devido à dragagem, canalização e estreitamento de canais e ao desflorestamento; e,

d) introdução de novas doenças na região, diante do aumento da migração populacional induzida e favorecida pela hidrovia.

Por outro lado, observam que os impactos positivos da hidrovia, em termos de geração de empregos e de produção, também devem ser considerados no cálculo dos benefícios. De modo geral, defendem que as análises de viabilidade econômica considerem, também, os impactos ambientais de forma explícita, de modo a ter uma avaliação adequada sobre a hidrovia. Isso deve ser feito para evitar que os ganhos econômicos a ela associados não resultem em grandes perdas ambientais e, conseqüentemente, de bem-estar para os países que adotam esse meio de transporte. Essa defesa também é feita por Brasil (2003c) cuja recomendação é aperfeiçoar os estudos dos projetos hidroviários, objetivando a redução das alterações ambientais decorrentes da implantação de barragens com eclusas e da formação de comboios.

No Brasil, a avaliação de impacto ambiental decorrente da implantação de empreendimentos que causem impactos ambientais, é regida pelas determinações legais do Conselho Nacional do Meio Ambiente (CONAMA) e fiscalizadas pelo Instituto Brasileiro do Meio Ambiente e dos Recursos Naturais Renováveis (IBAMA). Segundo CONAMA (1986) "impacto ambiental" é entendido como qualquer alteração das propriedades físicas, químicas e biológicas do meio ambiente, causada por qualquer forma de matéria ou energia resultante das atividades humanas que, direta ou indiretamente, afetem a saúde, a segurança e o bem-estar da população; as atividades sociais e econômicas; a biota; as condições estéticas e sanitárias do meio ambiente; e a qualidade dos recursos ambientais. Diante disso, o 
Conselho determina que o licenciamento de atividades modificadoras do meio ambiente depende da elaboração de EIA e respectivo RIMA. Dentre essas atividades estão incluídas estradas de rodagem com duas ou mais faixas de rolamento, ferrovias, portos e terminais de minério, petróleo e produtos químicos, aeroportos e obras hidráulicas para exploração de recursos hídricos, tais como: barragem para fins hidrelétricos acima de $10 \mathrm{MW}$, de saneamento ou de irrigação, abertura de canais para navegação, drenagem e irrigação, retificação de cursos d'água, abertura de barras e embocaduras, transposição de bacias e diques.

No caso da Hidrovia Tocantins-Araguaia, a AHITAR, promoveu a avaliação dos impactos ambientais e sócio-econômicos inicialmente delimitando a área de influência direta e indireta da hidrovia em função dos espaços físico, biótico e antrópico suscetíveis de alterações decorrentes da implantação, manutenção e operação do empreendimento. Vale observar que os estudos físico e biótico não se limitam às divisas estaduais e municipais, pois obedecem fronteiras e limites naturais. Já o antrópico mantém relação com a organização político-administrativa das regiões sob influência dessa modalidade de transporte. Em seguida, AHITAR (1999) assinala a realização das seguintes etapas:

a) identificação dos elementos ambientais afetados pelo projeto na construção, operação e manutenção e os elementos mais expostos ou sensíveis às atividades do empreendimento;

b) descrição dos componentes técnicos do projeto durante as fases de construção (operação de acampamentos produzindo desmatamento e decapeamento, dragagem de areia, derrocamento, lançamento e transporte de materiais) e a fase de operação (manutenção e conservação das vias, das instalações portuárias, dos equipamentos de navegação, dragagem, implantação dos portos ou terminais, balizamento e sinalização); 
c) elaboração de uma matriz interativa ambiental que apresenta as principais interações entre as atividades técnicas ou tecnológicas do projeto com os indicadores ambientais, permitindo melhor avaliação dos impactos ambientais observados e uma rápida constatação do nível de impacto de cada atividade, segundo o indicador e o elemento ambiental;

d) construção do plano de manejo ambiental, incluindo medidas de prevenção e mitigação dos efeitos ambientais negativos do projeto, medidas de compensação dos efeitos não mitigáveis, premissas para o plano diretor da Hidrovia com a finalidade de transferir benefícios às comunidades, diretrizes para a inserção regional do empreendimento e o monitoramento das medidas propostas;

Os impactos anotados nos meios físico, biótico e antrópico por AHITAR (1999), classificados segundo a metodologia adotada para o estudo de impacto ambiental (EIA), estão apresentados nas Tabelas 11, 12 e 13. 
Tabela 11. Impactos ambientais sobre o meio físico, associados à implantação, operação e manutenção da Hidrovia Tocantins-Araguaia, Brasil

\begin{tabular}{|c|c|c|c|c|c|c|}
\hline $\begin{array}{c}\text { EFEITO } \\
\text { AMBIENTAL }\end{array}$ & $\begin{array}{l}\text { MAGNI- } \\
\text { TUDE }\end{array}$ & DURAÇÃO & $\begin{array}{l}\text { AREA } \\
\text { INFLUÊN- } \\
\text { CIA }\end{array}$ & $\begin{array}{l}\text { MITIGA- } \\
\text { BILIDADE }\end{array}$ & $\begin{array}{l}\text { IMPLICA- } \\
\text { ÇÕES }\end{array}$ & $\begin{array}{l}\text { RELE- } \\
\text { VÃNCIA }\end{array}$ \\
\hline \multicolumn{7}{|l|}{ Geral } \\
\hline $\begin{array}{l}\text { Emissão de } \\
\text { ruídos e gases }\end{array}$ & Baixa & Permanente & Local & Pouca & $\begin{array}{l}\text { Física e } \\
\text { Biótica }\end{array}$ & Baixa \\
\hline $\begin{array}{l}\text { Emissão de } \\
\text { partículas }\end{array}$ & Baixa & Curta & Local & Alta & $\begin{array}{l}\text { Física e } \\
\text { Biótica }\end{array}$ & Baixa \\
\hline $\begin{array}{l}\text { Ampliação de } \\
\text { mineração }\end{array}$ & Moderada & Permanente & Regional & & Econômica & Moderada \\
\hline \multicolumn{7}{|c|}{ Bacia Araguaia e Mortes } \\
\hline $\begin{array}{l}\text { Intensificação } \\
\text { de erosão }\end{array}$ & Moderada & Permanente & Regional & Moderada & $\begin{array}{l}\text { Física e } \\
\text { Social }\end{array}$ & Alta \\
\hline $\begin{array}{l}\text { Alteração no } \\
\text { uso dos solos }\end{array}$ & Moderada & Permanente & Regional & Moderada & $\begin{array}{l}\text { Física e } \\
\text { Social }\end{array}$ & Alta \\
\hline $\begin{array}{l}\text { Alteração na } \\
\text { qualidade das } \\
\text { águas } \\
\text { superficiais } \\
\text { Planícies de inun }\end{array}$ & Moderada & Permanente & Regional & Moderada & $\begin{array}{l}\text { Física e } \\
\text { Social }\end{array}$ & Alta \\
\hline $\begin{array}{l}\text { Instabilidade de } \\
\text { taludes } \\
\text { marginais } \\
\text { naturais }\end{array}$ & Alta & Estacional & Zonal & Pouca & Física & Moderada \\
\hline $\begin{array}{l}\text { Alterações na } \\
\text { morfologia }\end{array}$ & Moderada & Permanente & Local & Pouca & $\begin{array}{l}\text { Física e } \\
\text { Social }\end{array}$ & Alta \\
\hline Degradação da & & & & & & \\
\hline $\begin{array}{l}\text { material de } \\
\text { dragagem, } \\
\text { derrocamento e } \\
\text { obras de apoio }\end{array}$ & Moderada & Estacional & Local & Moderada & Física & Moderada \\
\hline Leito dos rios & & & & & & \\
\hline $\begin{array}{l}\text { Alterações no } \\
\text { transporte e } \\
\text { deposição de } \\
\text { sólidos pela } \\
\text { dragagem e } \\
\text { derrocamento }\end{array}$ & Alta & Permanente & Local & Moderada & $\begin{array}{l}\text { Física e } \\
\text { Social }\end{array}$ & Alta \\
\hline $\begin{array}{l}\text { Modificações na } \\
\text { dinâmica do } \\
\text { fluxo das águas }\end{array}$ & Moderada & Curta & Local & Moderada & $\begin{array}{l}\text { Física e } \\
\text { Social }\end{array}$ & Moderada \\
\hline $\begin{array}{l}\text { Alterações na } \\
\text { qualidade e uso } \\
\text { das drogas }\end{array}$ & Moderada & Curta & Zonal & Alta & $\begin{array}{l}\text { Física e } \\
\text { Social }\end{array}$ & Moderada \\
\hline
\end{tabular}

Fonte: AHITAR (1999) 
Tabela 12. Impactos ambientais sobre o meio biótico (fauna), associados à implantação, operação e manutenção da Hidrovia TocantinsAraguaia, Brasil

\begin{tabular}{|c|c|c|c|c|c|c|}
\hline $\begin{array}{c}\text { EFEITO } \\
\text { AMBIENTAL }\end{array}$ & $\begin{array}{l}\text { MAGNI- } \\
\text { TUDE }\end{array}$ & DURAÇÃO & $\begin{array}{l}\text { AREA } \\
\text { INFLUÊN- } \\
\text { CIA }\end{array}$ & $\begin{array}{l}\text { MITIGA- } \\
\text { BILIDADE }\end{array}$ & $\begin{array}{l}\text { IMPLICA- } \\
\text { ÇÕES }\end{array}$ & $\begin{array}{l}\text { RELE- } \\
\text { VÃNCIA }\end{array}$ \\
\hline $\begin{array}{l}\text { Interferência na } \\
\text { homeostase da } \\
\text { comunidade }\end{array}$ & Alto & Permanente & Regional & Média & $\begin{array}{l}\text { Qualid. } \\
\text { biótica }\end{array}$ & Alto \\
\hline $\begin{array}{l}\text { Interferência em } \\
\text { cadeias trópicas }\end{array}$ & Alto & Estacional & $\begin{array}{l}\text { Extra } \\
\text { regional }\end{array}$ & Média & $\begin{array}{l}\text { Qualid. } \\
\text { biótica }\end{array}$ & Alto \\
\hline $\begin{array}{l}\text { Alteraçãoda } \\
\text { qualidade } \\
\text { biótica dos rios }\end{array}$ & Moderado & Estacional & Regional & Média & $\begin{array}{l}\text { Qualid. } \\
\text { Biótica }\end{array}$ & Alto \\
\hline $\begin{array}{l}\text { Interferência na } \\
\text { migração e } \\
\text { reprodução da } \\
\text { ictiofauna }\end{array}$ & Moderado & Estacional & $\begin{array}{l}\text { Extra } \\
\text { regional }\end{array}$ & Média & Biótica & Alto \\
\hline $\begin{array}{l}\text { Interferência na } \\
\text { reprodução de } \\
\text { quelônios }\end{array}$ & Moderado & Estacional & Zonal & Média & Biótica & Alto \\
\hline $\begin{array}{l}\text { Interferência em } \\
\text { áreas de inte- } \\
\text { resse ecológico }\end{array}$ & Muito Alto & Estacional & Zonal & Total & Biótica & Muito Alto \\
\hline $\begin{array}{l}\text { Aceleração de } \\
\text { antropização na } \\
\text { área influência }\end{array}$ & Alto & Permanente & $\begin{array}{c}\text { Extra } \\
\text { Regional }\end{array}$ & Pouco & Biótica & Alto \\
\hline $\begin{array}{l}\text { Simplificação } \\
\text { da comunidade } \\
\text { faunística }\end{array}$ & Moderado & Permanente & Regional & Média & Biótica & Alto \\
\hline $\begin{array}{l}\text { Acréscimo da } \\
\text { pressão antró- } \\
\text { pica sobre a } \\
\text { fauna regional }\end{array}$ & Moderado & Permanente & Regional & Alto & Biótica & Alto \\
\hline $\begin{array}{l}\text { Alteração de } \\
\text { habitats } \\
\text { aquáticos }\end{array}$ & Alto & Estacional & Regional & Pouco & $\begin{array}{l}\text { Qualid. } \\
\text { Biótica }\end{array}$ & Alto \\
\hline $\begin{array}{l}\text { Alteração de } \\
\text { habitats } \\
\text { terrestres }\end{array}$ & Moderado & Estacional & Regional & Média & $\begin{array}{l}\text { Qualid. } \\
\text { Biótica }\end{array}$ & Moderado \\
\hline $\begin{array}{l}\text { Transmigração } \\
\text { pragas, vetores } \\
\text { e zoonoses }\end{array}$ & Moderado & Permanente & $\begin{array}{l}\text { Extra } \\
\text { regional }\end{array}$ & Média & Biótica & Alto \\
\hline
\end{tabular}

Fonte: AHITAR (1999) 
Tabela 13. Impactos ambientais sobre o meio antrópico, associados à implantação, operação e manutenção da Hidrovia TocantinsAraguaia, Brasil

\begin{tabular}{|c|c|c|c|c|c|c|}
\hline $\begin{array}{c}\text { EFEITO } \\
\text { AMBIENTAL }\end{array}$ & $\begin{array}{l}\text { MAGNI- } \\
\text { TUDE }\end{array}$ & DURAÇÃO & $\begin{array}{l}\text { AREA } \\
\text { INFLUÊN- } \\
\text { CIA } \\
\end{array}$ & $\begin{array}{l}\text { MITIGA- } \\
\text { BILIDADE }\end{array}$ & $\begin{array}{l}\text { IMPLICA- } \\
\text { ÇÕES }\end{array}$ & $\begin{array}{l}\text { RELE- } \\
\text { VÃNCIA }\end{array}$ \\
\hline \multicolumn{7}{|c|}{ Atividades Econômicas } \\
\hline $\begin{array}{l}\text { Incremento da } \\
\text { atividade agro- } \\
\text { pastoris e pro- } \\
\text { dução agrícola }\end{array}$ & Alta & Permanente & $\begin{array}{c}\text { Extra- } \\
\text { Regional }\end{array}$ & & $\begin{array}{l}\text { Sócio- } \\
\text { econômica }\end{array}$ & Alta \\
\hline $\begin{array}{l}\text { Desmatamento } \\
\text { - Irrigação }\end{array}$ & Alta & Moderada & Regional & Pouca & $\begin{array}{l}\text { Físico- } \\
\text { biológica }\end{array}$ & Alta \\
\hline Silvicultura & Moderada & Permanente & Local & Pouca & Biológica & Alta \\
\hline Comerciais & Moderada & & Local & & $\begin{array}{l}\text { Sócio- } \\
\text { econômica }\end{array}$ & Moderada \\
\hline Agro-industrias & Baixa & Permanente & Local & & $\begin{array}{l}\text { Sócio- } \\
\text { econômica }\end{array}$ & Moderada \\
\hline $\begin{array}{l}\text { Desenv. da } \\
\text { infra-estrutura }\end{array}$ & Moderada & Permanente & Regional & & $\begin{array}{l}\text { Sócio- } \\
\text { econômica }\end{array}$ & Moderada \\
\hline Estrutura Agrária & & & & & & \\
\hline $\begin{array}{l}\text { Alteração do } \\
\text { valor da terra }\end{array}$ & Moderada & Moderada & Regional & & $\begin{array}{l}\text { Sócio- } \\
\text { econômica }\end{array}$ & Alta \\
\hline $\begin{array}{l}\text { Concentração } \\
\text { fundiária }\end{array}$ & Moderada & Permanente & Regional & Pouca & $\begin{array}{l}\text { Sócio- } \\
\text { econômica }\end{array}$ & Alta \\
\hline $\begin{array}{l}\text { Geração de } \\
\text { empregos } \\
\text { Comunidades }\end{array}$ & Moderada & Moderada & Regional & & $\begin{array}{l}\text { Sócio- } \\
\text { econômica }\end{array}$ & Moderada \\
\hline $\begin{array}{l}\text { Melhoria quali- } \\
\text { dade de vida }\end{array}$ & Moderada & Permanente & Regional & & $\begin{array}{l}\text { Sócio- } \\
\text { econômica }\end{array}$ & Moderada \\
\hline $\begin{array}{l}\text { Melhoria quali- } \\
\text { dade de ensino }\end{array}$ & Moderada & Permanente & Regional & & $\begin{array}{l}\text { Sócio- } \\
\text { cultural }\end{array}$ & Moderada \\
\hline $\begin{array}{l}\text { Melhoria da } \\
\text { situação pública }\end{array}$ & Moderada & Permanente & Regional & & Social & Moderada \\
\hline $\begin{array}{l}\text { Incremento } \\
\text { populacional } \\
\text { Turismo }\end{array}$ & Moderada & Permanente & Regional & Pouca & Social & Moderada \\
\hline $\begin{array}{l}\text { Interferência na } \\
\text { recreação }\end{array}$ & Alta & Permanente & Regional & Pouca & Lazer & Alta \\
\hline $\begin{array}{l}\text { Interferência na } \\
\text { pesca }\end{array}$ & Moderada & Permanente & Zonal & Pouca & Lazer & Alta \\
\hline $\begin{array}{l}\text { Incremento ao } \\
\text { turismo }\end{array}$ & Moderada & Permanente & Regional & & $\begin{array}{l}\text { Sócio- } \\
\text { econômica }\end{array}$ & Alta \\
\hline
\end{tabular}

Fonte: AHITAR (1999) 
O exame dessas tabelas revela que os impactos têm, predominantemente, baixa a moderada magnitude, duração estacional ou permanente, área de influência local ou regional, pouca ou moderada mitigabilidade e relevância moderada ou alta. Essa visão geral permite o planejamento de medidas mitigadoras, maximizadoras e compensatórias, a serem desenvolvidas pela Administradora durante as fases de implantação, operação e manutenção da Hidrovia Tocantins-Araguaia. As medidas mitigadoras objetivam minimizar os impactos negativos previstos pela implantação do empreendimento, originados por ações diretas ou indiretas praticadas ou provocadas pelo empreendedor. As medidas maximizadoras têm por função potencializar os efeitos positivos provocados ou induzidos pelo empreendimento. Neste grupo merecem destaque a intensificação das atividades produtivas, a melhoria das condições de escoamento da produção agrícola e a incorporação de novas áreas ao processo de produção, dentro dos conceitos de equilíbrio e de sustentabilidade ambiental. As medidas compensatórias, por sua vez, buscam dar ao ambiente afetado a compensação por impactos não mitigados parcial ou totalmente.

A fragilidade dos ecossistemas afetados pelo empreendimento da Hidrovia Tocantins-Araguaia exige do empreendedor o estabelecimento de planos de monitoramento específico, cujo objetivo principal é monitorar a qualidade biótica dos rios no período das obras de implantação e de monitoramento rotineiro ou permanente em função da repetitividade que caracteriza, principalmente, as obras de derrocamento e dragagem, que afetam a qualidade das águas, a cadeia alimentar faunística e os aspectos sócioeconômicos das comunidades envolvidas. AHITAR (1999) ainda destaca o acompanhamento das atividades econômicas, destacando as questões relativas ao uso agrícola do solo, ou seja, à expansão da agricultura e pecuária no entorno da hidrovia. Utilizando imagens de satélite pretende-se o acompanhamento quantitativo das safras agrícolas e da expansão da área 
agropecuária, bem como da tipologia dos produtos agrícolas. Tais informações permitem estimar a degradação da cobertura vegetal, possíveis impactos do uso do potencial hidrológico e a localização das áreas de plantio ou de pastagens em relação a compartimentos de risco ambiental como cabeceiras de sistema hidrográfico, fundos de vale ou áreas de inundação. Permitem, também, constatar a tendência da atividade agrícola em relação ao mercado destinatário, além da relação com possíveis alterações na estrutura fundiária.

Apesar da hidrovia ser um caminho natural, é considerada de alto risco devido à utilização de recursos naturais finitos pertencentes a ecossistemas potencialmente frágeis. Essa preocupação é levantada tanto pela Administradora quanto por outras instituições interessadas na proteção do meio ambiente. Nesse contexto, a Fundação Centro Brasileiro de Referência e Apoio Cultural (CEBRAC) (2000) analisou o Estudo de Impacto Ambiental (EIA) e o Relatório de Impactos Ambiental (RIMA) elaborados pela AHITAR. Na oportunidade, procurou verificar se o EIA apresentado identificava e apresentava os impactos ambientais, sociais e econômicos relacionados à estruturação da Hidrovia, bem como as alternativas existentes e as medidas mitigadoras dos impactos negativos, tomando por base as determinações legais estabelecidas pelo CONAMA. De modo geral, concluiu que o EIA-RIMA da AHITAR apresenta sérias divergências e discrepâncias, relativas aos custos totais, às obras de engenharia necessárias e aos impactos ambientais diretos e indiretos do projeto. Dentre os efeitos negativos relacionados à implantação e operação da Hidrovia Tocantins-Araguaia, CEBRAC (2000) assinala: mudança no modo de vida e perda de bem-estar das populações indígenas e ribeirinhas; substituição indiscriminada de matas e florestas por culturas agrícolas; perda de fertilidade e salinização dos solos devido à irrigação descontrolada; contaminação das águas por resíduos agropecuários e industriais; erosão e assoreamento dos rios; perda de biodiversidade, incluindo a mortalidade de peixes devido à menor oxigenação da água. Além desses, há o fato de que o 
derrocamento pode causar sérias modificações na dinâmica hidrológica e na geomorfologia dos rios, podendo provocar mudanças significativas e danosas em todo o ecossistema. Outro aspecto é que as medidas mitigadoras, quando apresentadas no EIA-RIMA, mostram-se apenas genéricas. Ademais, ressalta que não se menciona o efeito da implantação da Hidrovia Tocantins-Araguaia sobre as populações social, cultural e economicamente dependentes dos rios que a compõem. Dúvidas sobre o impacto apontado pela AHITAR no ecoturismo também são levantadas, fazendo referência ao fato de que as cidades ao longo da Hidrovia do Mississipi, nos EUA, especializaram-se em produção industrial e prestação de serviços e, não, em turismo. Adicionalmente, o projeto da Hidrovia Tocantins-Araguaia conflita com os objetivos de desenvolvimento sustentável estabelecidos, principalmente, para a região do rio Araguaia, tal como o Polo Turístico do Cantão, próximo à Ilha do Bananal. Finalmente, afirma que a Hidrovia Tocantins-Araguaia não se constitui em alternativa de transporte viável para o cerrado e para a Região Centro-Oeste, recomendando a busca de outros modelos de transporte de cargas e de passageiros que não degradem o ambiente e não depreciem o valor dos capitais humano e natural da região.

A diferença entre as conclusões da AHITAR e do CEBRAC sobre os impactos da Hidrovia Tocantins-Araguaia na economia, sociedade e meio ambiente dos municípios lindeiros reforçam a importância do método de avaliação econômica adequado a um projeto de infra-estrutura de transporte. $\mathrm{O}$ método deve possibilitar a identificação e o dimensionamento dos impactos para a população, sociedade e economia que a infra-estrutura influencia, favorecendo a avaliação e a tomada de decisão conjunta por proponentes e beneficiários. Essa discussão é desenvolvida a seguir. 


\subsubsection{Viabilidade econômica}

O papel da infra-estrutura de transporte do Estado do Tocantins como fator de crescimento e desenvolvimento econômicos é significativo em termos locais e regionais, segundo a Japan International Cooperation Agency (JICA) (1998). Vale lembrar que, por estar situada em uma região de trânsito, a infra-estrutura de transporte tocantinense atende também a outros estados da Federação, influenciando fortemente as atividades e expectativas dos agentes econômicos neles localizados.

Considerando 0 potencial para influenciar positivamente 0 crescimento e o desenvolvimento dos municípios, estados e regiões abrangidos, AHITAR (1999) procurou estabelecer a viabilidade econômica da Hidrovia Tocantins-Araguaia, amparando-se em dados básicos, obtidos em fontes como a Empresa Brasileira de Planejamento de Transportes (GEIPOT), encarregada do planejamento do setor de transportes em nível federal e, ainda, de estudo desenvolvido pela Engenharia, Construções e Ferrovias S.A. (VALEC), responsável pela implantação da Ferrovia Norte-Sul, apontada como uma alternativa à hidrovia. No intuito de estimar a viabilidade econômica efetiva da Hidrovia Tocantins-Araguaia em seus diversos segmentos e na composição com outras alternativas, a Administradora considerou os seguintes parâmetros básicos:

a) período de análise de 20 anos;

b) taxa de retorno do capital investido de $12 \%$ ao ano;

c) custos de investimentos relativos apenas às despesas com a implantação da hidrovia;

d) estimativa de despesas anuais com custo de conservação correspondente a $5 \%$ do custo de implantação da hidrovia; e, 
e) benefícios computados como $1 / 3$ no primeiro ano de operação, 2/3 no segundo e integrais no terceiro.

Com tais parâmetros, foram encontrados os resultados a seguir::

a) relação benefício / custo $(\mathrm{RBC})=18,3$; e,

b) taxa interna de retorno $(\mathrm{TIR})=117,5 \%$ ao ano.

Para testar a sensibilidade dos indicadores de rentabilidade do empreendimento sob algumas variações desfavoráveis modificaram-se os parâmetros básicos para a análise de viabilidade:

a) período de análise de 20 anos;

b) taxa de retorno do capital investido de $12 \%$ ao ano;

c) dobro dos custos de investimento estimados;

d) estimativa de despesas anuais com custo de conservação correspondente a $10 \%$ custo de investimento;

e) benefícios reduzidos à metade, computados como $1 / 3$ no primeiro ano de operação, 2/3 no segundo e integrais no terceiro.

Desta feita, as estimativas foram as seguintes:

a) relação benefício-custo $(\mathrm{RBC})=3,0$;

b) taxa interna de retorno $(T I R)=42,1 \%$;

Á luz dos resultados, AHITAR (1999) conclui que o empreendimento Hidrovia Tocantins-Araguaia é economicamente viável, "revelando indicadores econômicos expressivos". Essa viabilidade econômica, porém, é contestada por CEBRAC (2000) ao alegar que a análise elaborada pela AHITAR considera 
apenas os custos de construção do projeto e de transporte através da hidrovia vis-à-vis os custos de transporte em outras modalidades. Os investimentos em infra-estrutura necessários ao funcionamento da hidrovia como elo de ligação entre estradas, ferrovias e portos não foram considerados. Observa, também, que a Ferrovia Norte-Sul surge como competidora direta da Hidrovia TocantinsAraguaia, com estimativas de custos de uso 67\% inferiores. Outrossim, não há referência aos custos de mitigação dos danos causados ao ambiente e às populações afetadas. Outro aspecto importante é o fato de que dragagem necessária para manter a hidrovia em condições operacionais deverá requerer, a cada ciclo anual, a remoção de um volume no mínimo equivalente ao retirado inicialmente, senão maior, implicando custos não desprezíveis. Além disso, os custos dos impactos ambientais e sociais públicos igualmente não são mensurados e incluídos no cálculo. Completando, a Fundação CEBRAC alerta que, na realidade, o projeto beneficiará um público restrito e coloca dúvidas sobre a existência de viabilidade econômica.

Vê-se, portanto, que a discussão sobre a avaliação da viabilidade econômica da Hidrovia Tocantins-Araguaia reflete a necessidade de inclusão de variáveis explícitas e implícitas, tangíveis e intangíveis na análise. Diante da amplitude de impactos que o projeto da Hidrovia alcança, os indicadores estimados através da análise benefício-custo podem não expressar a realidade e a totalidade dos benefícios e custos decorrentes do projeto. Sobre isso, Barkin (1996) assinala que a análise benefício-custo é inadequada para examinar a viabilidade econômica e o impacto ambiental de um projeto complexo como o de uma hidrovia. As mudanças alcançam os sistemas econômicos, as estruturas sociais e o meio ambiente das comunidades locais, dos países e do capital privado envolvidos. Contudo, a maioria dos instrumentos analíticos de avaliação de projetos é desenvolvida para examinar apenas mudanças marginais nos sistemas produtivos. A consciência da necessidade de incorporar alguns dos custos e benefícios externos dos 
investimentos públicos esbarra nas dificuldades metodológicas e instrumentais de incorporar no cálculo a magnitude das mudanças estruturais provocadas por projetos da envergadura de uma hidrovia. Por outro lado, Bucher \& Huszar (1996) argumentam que a análise benefício-custo pode ser utilizada para a avaliação, desde que aos custos e benefícios externos reconhecidos sejam estabelecidas ponderações que permitam incluí-los nas estimativas de retornos líquidos. Porém, alertam que a dificuldade está na identificação e dimensionamento dessas externalidades. Nesse aspecto, inclusive, concordam com Barkin (1995) sobre o fato de que novas metodologias devam ser desenvolvidas para analisar os projetos sob os pontos de vista micro e macroeconômico. Deve-se analisar os projetos hidroviários e os seus acessos terrestres, incluindo os terminais de transbordo pela articulação com os modais envolvidos, visando a otimização dos investimentos e a redução progressiva dos custos operacionais, bem como complementar os projetos propostos com estudos econômicos mais abrangentes, quantificando os custos e benefícios diretos e indiretos, visando a completa avaliação econômico-financeira dessas implantações. Essa preocupação em relação à avaliação ampla dos impactos dos projetos de infra-estrutura de transporte ressalta a necessidade da utilização de métodos que alcancem os principais impactos envolvidos, de modo a favorecer uma análise ampla da infra-estrutura pública de transporte. Esse é o tema do próximo Capítulo. 


\section{IMPORTÂNCIA E IMPACTOS DA HIDROVIA TOCANTINS-ARAGUAIA: MATERIAL E MÉTODO DE PESQUISA}

A relevância dos impactos dos projetos de infra-estrutura de transporte ressalta a necessidade da utilização de métodos de avaliação que identifiquem e dimensionem os principais impactos envolvidos, de modo a favorecer uma escolha econômica, social e ambiental mais adequada ao desenvolvimento do projeto. Nesse contexto de avaliação ampla é que o presente estudo propõe o levantamento dos impactos causados pela Hidrovia Tocantins-Araguaia e, também, que isso seja feito sob o ponto de vista dos diferentes agentes econômicos localizados nos principais municípios tocantinenses lindeiros aos rios Araguaia e Tocantins. Tais proposições têm por finalidade captar as impressões e expectativas dos potenciais usuários sobre os possíveis impactos, oferecendo um complemento à visão dos idealizadores do projeto (já conhecida através do estudo impactos ambientais - EIA) e possibilitando uma avaliação mais abrangente e equilibrada dos benefícios e custos da infra-estrutura. Para isso é necessária a identificação das informações a serem captadas, dos usuários a serem entrevistados, do instrumento de coleta dos dados e da forma de tratamento estatístico das informações. Esse processo é o tema deste Capítulo. 


\subsection{Variáveis de interesse ao estudo}

As informações necessárias ao estudo da importância e dos impactos econômicos, sociais e ambientais da Hidrovia Tocantins-Araguaia, sob o ponto de vista dos entrevistados, são definidas na forma de variáveis relacionadas a três áreas de interesse: serviços prestados pela infra-estrutura ao município, possíveis impactos econômicos, sociais e ambientais, importância geral e presença nos projetos locais, públicos ou privados, em andamento ou em elaboração. A respeito dos serviços prestados ao município, busca-se o grau de conhecimento e de informação do entrevistado sobre aspectos relacionados à hidrovia como um todo, ao estágio de implantação no município, à estrutura operacional disponível na localidade e à importância e acessibilidade aos principais serviços por ela prestados, quais sejam, o transporte de mercadorias (insumos e produtos), de pessoas, de animais e atividades de turismo. Quanto aos possíveis impactos no município, têm-se, dentre os econômicos as variações na agricultura, indústria e comércio, turismo, valor das propriedades ribeirinhas, oportunidades locais de negócios, arrecadação e gastos municipais. Dentre os sociais encontram-se mudanças na prestação de serviços públicos estruturais ${ }^{10}$ e sociais ${ }^{11}$, integração de regiões e comunidades locais com outras regiões e comunidades e na oferta de atividades culturais e de espaços de lazer para a população. Nos ambientais, por sua vez, inserem-se modificações na diversidade da fauna, da flora e da qualidade da água, assim como na ocorrência de cheias e enchentes. No que tange à importância geral para o município, o entrevistado deve dimensioná-la, bem como declarar sua opinião sobre a possibilidade do investimento municipal e institucional/empresarial para a implantação dessa infra-estrutura, em função da importância que the atribui. Associado a isso, busca-se a presença da

\footnotetext{
${ }^{10}$ Entendam-se serviços públicos estruturais como construção e manutenção de benfeitorias, pavimentação asfáltica, eletrificação urbana e rural e comunicação por telefone e satélite.

${ }^{11}$ Entendam-se serviços públicos sociais como a oferta de serviços de saúde, creche e de proteção, assistência e promoção social.
} 
hidrovia nos projetos do setor que o entrevistado representa, solicitando que descreva aqueles onde ela está presente ou, então, que identifique os motivos da não incorporação. A Figura 7 ilustra a estruturação das variáveis de interesse ao estudo.

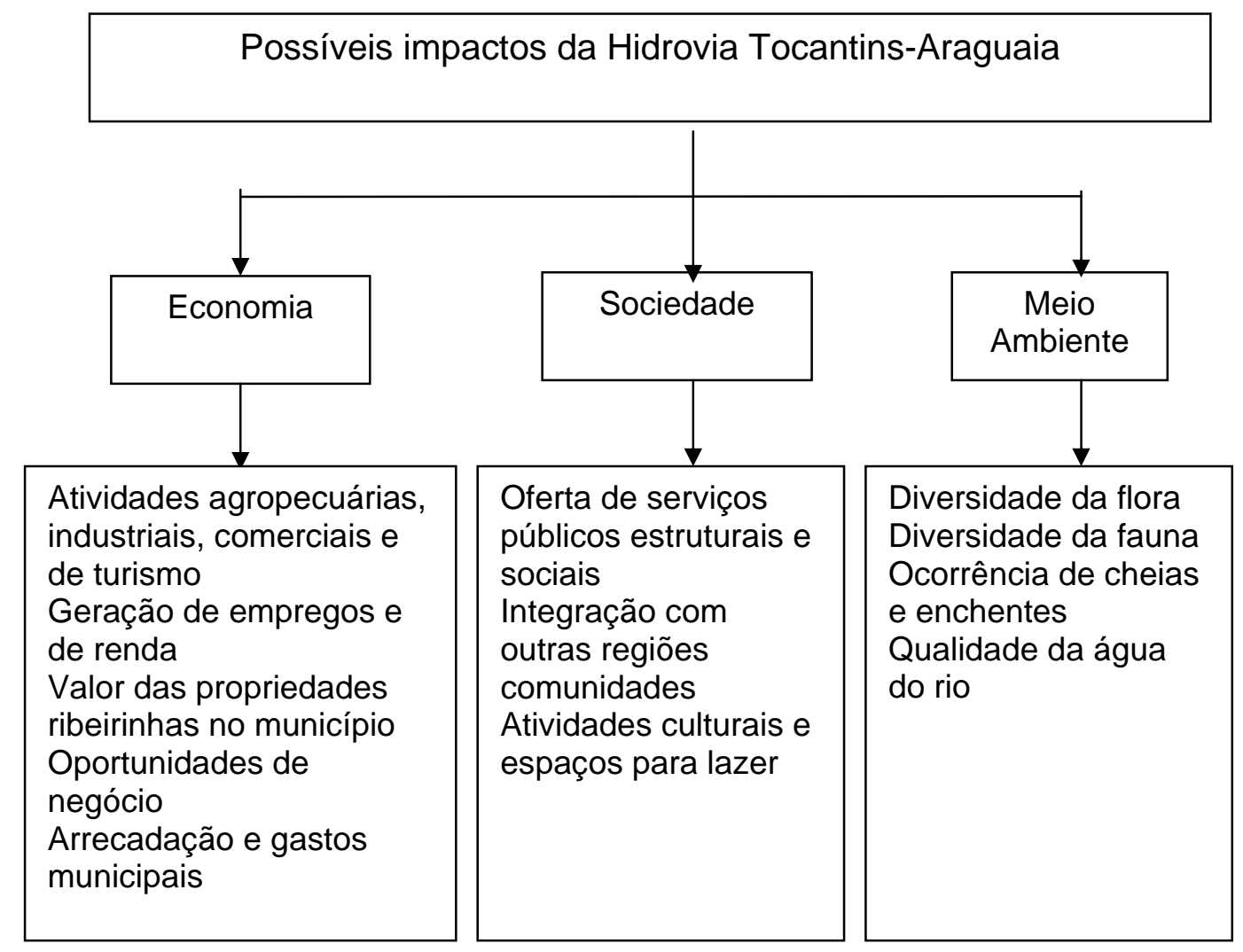

Figura 7 - Setores e atividades que podem ser influenciados pela presença da Hidrovia Tocantins-Araguaia, Brasil

Fonte: dados da pesquisa

\subsection{Método de coleta de dados e de informações}

A captação de dados sobre a Hidrovia Tocantins-Araguaia será desenvolvida em duas formas distintas: através da realização de entrevistas 
individuais e da organização de grupos focais. A primeira visa a captar impressões particulares dos agentes entrevistados através da aplicação de questionário específico. A segunda, objetiva colher impressões coletivas de grupos de diferentes agentes econômicos, em reuniões organizadas com a finalidade de discutir a hidrovia. Cada forma é apresentada a seguir.

\subsubsection{Entrevistas individuais}

O método escolhido para a captação das informações é a entrevista direta, realizada pessoalmente com potenciais usuários diretos ou indiretos dos serviços prestados pela Hidrovia Tocantins-Araguaia. Esse contato pessoal permite maior interação com o entrevistado, favorece a qualificação das respostas, bem como permite visualizar o contexto local que influencia a expectativa do entrevistado. Contudo, deve-se estar ciente que além do risco de um comportamento excessivamente auto-interessado por parte do entrevistado estar presente na entrevista, outros aspectos relacionados à capacidade dos entrevistados em analisar os impactos sobre a hidrovia também se fazem presentes.

Sobre a utilização de entrevistas como método de captação dos dados sobre infra-estrutura pública de transporte, Bruinsma \& Rietveld (1997) observam que uma das dificuldades desse método, em nível regional, para mensurar o impacto da construção de infra-estrutura de transporte é a distinção entre os efeitos gerais e os distributivos. Uma questão que se estabelece é se os efeitos dos investimentos em infra-estrutura, como percebidos pelos empresários, são apenas a conseqüência de uma redistribuição espacial no emprego e nos arredores ou se estão relacionados, por exemplo, ao crescimento agregado da economia. Outra questão é a dificuldade dos empregadores em distinguir a influência de uma mudança na infra-estrutura da influência de mudanças na estrutura de produção econômica regional total e no 
ambiente. Além disso, os empresários podem ter a tendência em superestimar os benefícios potenciais dos projetos de infra-estrutura na esperança de que os resultados da pesquisa convençam os tomadores de decisão de que os projetos devam ser levados a diante. Outra limitação apontada pelos autores, são os efeitos da infra-estrutura de transporte sobre as famílias, que podem não ser captados pelos questionários. Como exemplo, cita-se o fato dos benefícios da melhor infra-estrutura de transporte estarem relacionados ao menor tempo de deslocamento para visitas sociais ou à obtenção de claros impactos sobre sua atividade econômica. Contudo, ainda que apenas parte desses problemas possa ser cercada pelos questionários, Bruinsma \& Rietveld (1997) concluem que, na relação entre a infra-estrutura de transporte e o desenvolvimento econômico, a percepção dos empresários sobre a importância dessa infraestrutura é fundamental. Adicionalmente, notam que a relevância da infraestrutura de transporte para os empresários está na realocação das firmas que ela permite, dada a redução do tempo de viagem, principalmente, quando favorecida pela localização dos centros fornecedores. Finalmente, verificam que, embora os empresários indiquem que a infra-estrutura em geral e a construção de estradas em particular possuam certa importância para o desenvolvimento do nível de emprego, as perspectivas de mercado e as questões internas das próprias empresas são mais valorizadas.

Um aspecto que deve ser notado é o fato de que as variáveis em questão têm a função básica de qualificar a importância e os impactos associados à Hidrovia Tocantins-Araguaia e, por isso, são consideradas categóricas. Isso coloca a necessidade de um tratamento estatístico específico para esse tipo de variável. Pereira (2001) assinala que o dado qualitativo é uma estratégia que pode ser utilizada na classificação de um fenômeno aparentemente imponderável que, sob premissas de "natureza ontológica e semântica" permite o reconhecimento do evento, a análise de seu comportamento e suas relações com outros eventos. Completando, assinala 
que o dado de natureza qualitativa é uma forma de quantificação do evento qualitativo que normatiza e confere um caráter objetivo à sua observação.

Quanto ao instrumento de captação das impressões dos potenciais usuários da Hidrovia Tocantins-Araguaia, opta-se por um questionário formado, predominantemente, por questões objetivas organizadas de modo que 0 entrevistado, primeiramente, reflita sobre a ocorrência do evento assinalado, em seguida sobre seu sentido e, depois, sobre sua intensidade. Esta última, deve ser avaliada numa escala que varia entre zero e 10. Sobre a escolha dessa escala para mensurar a intensidade, vale observar que foi estabelecida no interesse particular de possibilitar o teste da hipótese básica deste estudo que estabelece a relação entre a importância atribuída à hidrovia e os impactos que ela possa causar na economia, sociedade e meio ambiente dos municípios lindeiros. A escolha apóia-se, também, no argumento de Pereira (2001, p.55) que assinala que "a fidedignidade da representação que os números fazem dos atributos é um juízo primário do investigador, o qual se apóia no seu conhecimento do objeto". O modelo do questionário a ser aplicado em campo encontra-se no Apêndice.

\subsubsection{Amostra de entrevistados}

A Hidrovia Tocantins-Araguaia, pela magnitude de suas dimensões, pode alcançar e influenciar, direta e indiretamente, o modo de vida, o meio ambiente e os negócios de um elevado número de indivíduos. Contudo, a inexistência de atividades relacionadas à hidrovia nos municípios dificulta encontrar pessoas que tenham conhecimento e/ou informações sobre essa infra-estrutura, resultando em uma população bastante reduzida que possa atender aos objetivos deste estudo. Assim, opta-se por reunir e/ou entrevistar representantes de diferentes grupos econômicos, sociais e ambientais nos principais municípios lindeiros aos rios Araguaia e Tocantins, como forma de 
captar impressões individuais, porém, representativas, sobre a importância e os impactos da hidrovia. Desse modo, a amostra que se pretende é intencional, o que, no caso das entrevistas individuais, pode trazer implicações quanto ao número de entrevistas e, conseqüentemente, de suficiência de observações para a análise estatística que se propõe. Todavia, diante da natureza das informações que se busca, esse tipo de amostragem ainda parece ser o mais apropriado. Como forma de contrabalançar essa possível limitação quantitativa firma-se o propósito de realizar grupos focais que permitam obter mais informações qualitativas sobre a hidrovia, através da sua discussão coletiva entre os participantes. Para esses grupos serão convidados agentes econômicos que sejam identificados como detentores de algum conhecimento e/ou informação sobre aquela infra-estrutura. Esses mesmos agentes podem ser conduzidos para entrevistas individuais.

No processo de seleção do tipo de indivíduo a ser reunido e/ou entrevistado, faz-se necessário, em primeiro lugar, estabelecer os grupos a serem representados. Assim é que se separam poder público e sociedade civil por entender que suas percepções diferem quanto à visão de necessidade, impactos, mudanças estruturais e potencial de geração de novas oportunidades econômicas e sociais pela hidrovia. Ainda que o poder público seja o legítimo representante da sociedade civil, o horizonte de planejamento, o contexto político e a forma de ação de cada um implicam diferenças nas expectativas sobre os resultados das infra-estruturas implantadas e planejadas. Em segundo lugar cabe separar as diferentes instâncias de representação de interesse para o presente estudo. No caso do poder publico, a atuação se dá no estado e no município. Nestes, a diferenciação se estabelece pelos níveis executivo, legislativo e judiciário. O executivo congrega as secretarias de município e de estado; o legislativo é representado pela câmara municipal e pela assembléia legislativa; e, o judiciário, pelo ministério público. A sociedade civil, por sua vez, se diferencia entre instituições de economia privada e instituições de proteção à 
sociedade organizada. A economia privada congrega os setores econômicos de agricultura, indústria, comércio e serviços. Nestes, buscam-se empresas, federações estaduais e associações de comércio e indústria municipais. A proteção à sociedade organizada é representada por entidades governamentais e não governamentais de proteção ao meio ambiente. Em cada instituição ou empresa privada visitada, deve-se procurar contatar os dirigentes e responsáveis principais ou seus assessores técnicos para obter suas impressões. O Quadro 3 resume a identificação dos agentes econômicos interessantes à pesquisa sobre a Hidrovia. 


\begin{tabular}{|c|c|c|c|c|c|}
\hline \multicolumn{6}{|c|}{ Estrutura Administrativa ou Operacional } \\
\hline \multirow{15}{*}{$\begin{array}{l}\text { Poder } \\
\text { Público }\end{array}$} & \multirow{8}{*}{ Estado } & \multirow{6}{*}{ Executivo } & Gabin. Governo & Gabinete & Governador \\
\hline & & & \multirow{5}{*}{$\begin{array}{l}\text { Secretaria } \\
\text { Estadual }\end{array}$} & Agricultura & \multirow{5}{*}{$\begin{array}{c}\text { Secretário, } \\
\text { Diretor, } \\
\text { Coordenador } \\
\text { de Área, } \\
\text { Técnico } \\
\text { Especialista }\end{array}$} \\
\hline & & & & Transporte & \\
\hline & & & & Infra-estrutura & \\
\hline & & & & $\begin{array}{c}\text { Indústria, } \\
\text { Comércio e } \\
\text { Turismo } \\
\end{array}$ & \\
\hline & & & & Planejamento & \\
\hline & & Legislativo & $\begin{array}{l}\text { Assembléia } \\
\text { Legislativa }\end{array}$ & Gabinete & $\begin{array}{c}\text { Deputado, } \\
\text { Assessor } \\
\text { Especialista } \\
\end{array}$ \\
\hline & & Judiciário & $\begin{array}{c}\text { Ministério } \\
\text { Público Estadual }\end{array}$ & Gabinete & $\begin{array}{l}\text { Promotor } \\
\text { Público } \\
\text { Estadual }\end{array}$ \\
\hline & \multirow{7}{*}{ Município } & \multirow{6}{*}{ Executivo } & Prefeitura & Gabinete & Prefeito \\
\hline & & & \multirow{5}{*}{$\begin{array}{l}\text { Secretaria } \\
\text { Municipal }\end{array}$} & Agricultura & \multirow{5}{*}{$\begin{array}{c}\text { Secretário, } \\
\text { Diretor, } \\
\text { Coordenador } \\
\text { de Área, } \\
\text { Técnico } \\
\text { Especialista }\end{array}$} \\
\hline & & & & Transporte & \\
\hline & & & & Infra-estrutura & \\
\hline & & & & $\begin{array}{l}\text { Indústria, } \\
\text { Comércio e } \\
\text { Turismo }\end{array}$ & \\
\hline & & & & Planejamento & \\
\hline & & Legislativo & $\begin{array}{l}\text { Câmara de } \\
\text { Vereadores }\end{array}$ & Gabinete & $\begin{array}{c}\text { Vereador, } \\
\text { Assessor } \\
\text { Especialista }\end{array}$ \\
\hline \multirow{5}{*}{$\begin{array}{l}\text { Sociedade } \\
\text { Civil }\end{array}$} & \multirow{3}{*}{$\begin{array}{c}\text { Economia } \\
\text { Privada }\end{array}$} & \multirow{3}{*}{$\begin{array}{c}\text { Setor } \\
\text { Econômico }\end{array}$} & \multirow{3}{*}{$\begin{array}{l}\text { Agricultura, } \\
\text { Indústria, } \\
\text { Comércio e } \\
\text { Serviços }\end{array}$} & Empresa & $\begin{array}{l}\text { Empresário } \\
\text { Atacadista } \\
\text { e/ou } \\
\text { Exportador }\end{array}$ \\
\hline & & & & $\begin{array}{l}\text { Cooperativas } \\
\text { de Produção }\end{array}$ & $\begin{array}{l}\text { Presidente, } \\
\text { Diretor }\end{array}$ \\
\hline & & & & $\begin{array}{l}\text { Associação } \\
\text { Comercial e } \\
\text { Industrial }\end{array}$ & $\begin{array}{l}\text { Presidente, } \\
\text { Diretor }\end{array}$ \\
\hline & \multirow{2}{*}{$\begin{array}{c}\text { Sociedade } \\
\text { Organizada }\end{array}$} & $\begin{array}{l}\text { Sociedade e } \\
\text { população }\end{array}$ & $\begin{array}{l}\text { Representação e } \\
\text { Proteção Social }\end{array}$ & \multirow{2}{*}{$\begin{array}{l}\text { Organização } \\
\text { Não } \\
\text { Governamental }\end{array}$} & \multirow{2}{*}{$\begin{array}{l}\text { Presidente, } \\
\text { Diretor, } \\
\text { Técnico } \\
\text { Especialista }\end{array}$} \\
\hline & & $\begin{array}{c}\text { Meio } \\
\text { Ambiente }\end{array}$ & $\begin{array}{c}\text { Representação e } \\
\text { Proteção } \\
\text { Ambiental }\end{array}$ & & \\
\hline
\end{tabular}

Quadro 3 - Agentes econômicos interessantes à pesquisa, localizados nos municípios da área de influência da Hidrovia Tocantins-Araguaia, Brasil

Fonte: dados da pesquisa 


\subsubsection{Modelo estatístico para análise dos dados}

A análise da percepção dos agentes econômicos sobre a importância e impactos da Hidrovia Tocantins-Araguaia pode ser desenvolvida segundo dois procedimentos estatísticos: análise qualitativa das impressões assinaladas pelos entrevistados e análise quantitativa da relação entre os impactos esperados e a importância dessa infra-estrutura. Na primeira análise, do tipo tabular, busca-se descrever, de forma qualitativa, o conhecimento do grupo ou do entrevistado sobre a presença da hidrovia em seu município, sobre os possíveis serviços que ela pode prover, sobre a ocorrência, sentido e intensidade de seus impactos econômicos, sociais e ambientais, bem como sobre a importância atribuída à hidrovia e sua inclusão nos projetos públicos ou privados locais. Na segunda, do tipo econométrica, utilizando um modelo estatístico pré-concebido, pretende-se avaliar a influência dos impactos na importância atribuída a essa infra-estrutura de transporte, utilizando um método de regressão linear do tipo stepwise (passo-à-passo). Para isso, faz-se necessário especificar o modelo estatístico a ser testado na análise econométrica. Nesse sentido, o modelo que se propõe considera, em linhas gerais, que a importância atribuída à Hidrovia Tocantins-Araguaia depende, principalmente, do tipo, sentido e intensidade dos impactos econômicos, sociais e ambientais que os entrevistados julgam que ela possa causar em seus municípios.

É esperado que os usuários entrevistados tenham capacidade para avaliar as implicações da presença da Hidrovia em seu município. Essa capacidade pode ser inferida pelo grau de escolaridade do indivíduo e pelo seu grau declarado de conhecimento e informação sobre essa infra-estrutura especifica. Contudo, fica difícil inferir se o sinal das relações entre a importância atribuída à hidrovia e a escolaridade ou, entre ela e o grau de conhecimento/informação do entrevistado, será positivo ou negativo, uma vez que, por exemplo, o fato de serem altos pode tanto levá-lo à conclusão de que 
essa infra-estrutura não seja importante ao município, quanto levá-lo à conclusão oposta.

Quanto aos possíveis impactos provocados pela Hidrovia TocantinsAraguaia nos municípios lindeiros, pode-se inferir, de maneira geral, que a importância está positivamente relacionada aos econômicos e sociais e negativamente relacionada aos ambientais. Espera-se que a hidrovia produza o aumento da atividade econômica dos municípios, assim como a melhoria da capacidade municipal de oferta de serviços públicos estruturais e sociais. Por outro lado, acredita-se que ela leve à perda de qualidade ambiental local.

Do ponto de vista econômico, espera-se que a importância da Tocantins-Araguaia tenha relação de sinal positivo com todos os setores ou atividades assinalados. Acredita-se, porém, que essa relação seja mais robusta com a expansão da agricultura, indústria, comércio e turismo, geração de emprego e renda e valorização das propriedades ribeirinhas no município, por se considerar que sejam afetados de maneira direta pela presença da hidrovia. Por sua vez, a relação positiva entre a importância da infra-estrutura e o aumento das oportunidades de negócio e da arrecadação e gastos municipais, deve ser mais moderada uma vez que, acredita-se, recebam influência menos direta da hidrovia.

Do ponto de vista social, a Hidrovia Tocantins-Araguaia tem sua importância relacionada com sinal positivo à maior oferta de serviços públicos estruturais e sociais necessários para atender o contingente de pessoas atraído pelos empregos gerados. A relação positiva também deve ser observada na disponibilização de atividades culturais e espaços para lazer no município, bem como na integração com outras regiões e comunidades.

Do ponto de vista ambiental, contudo, acredita-se que a relação dos impactos sobre fauna, flora e qualidade da água no município apresente sinal negativo frente à importância da presença municipal da Hidrovia Tocantins- 
Araguaia. Tanto a construção do canal navegável, por interferir na direção e profundidade dos leitos dos rios, quanto a operação e manutenção da hidrovia devem provocar a diminuição da variedade de espécies animais e vegetais. Além disso, acredita-se que a qualidade da água diminua, pelo trânsito das embarcações e possíveis vazamentos de óleo combustível e de outros poluentes. Interessante é que, ainda que o sinal esperado seja negativo entre a importância da Hidrovia e a ocorrência de cheias e enchentes dos rios nos municípios, isso pode ser entendido como um resultado favorável pois, a diminuição desse tipo de ocorrência, em função do controle do volume de água dos canais navegáveis, propiciado pelas barragens e leitos artificiais, evita sérios danos econômicos e sociais aos municípios, bem como favorece a irrigação de áreas agricultáveis ribeirinhas.

Estabelecido o modelo estatístico, cabe, a seguir, assinalar as características do método de regressão linear do tipo stepwise a ser utilizado na análise econométrica.

\subsubsection{Método de regressão stepwise}

A escolha do método para a análise econométrica do modelo estatístico proposto leva em conta o caráter exploratório do estudo e a inexistência de estudos semelhantes disponíveis na literatura. Diante disso, opta-se por utilizar um procedimento que considere o maior número de variáveis explicativas, dentro de um nível de confiança pré-estabelecido. Assim é que foi escolhida a regressão do tipo stepwise para testar a importância da Hidrovia Tocantins-Araguaia para o município, declarada pelo entrevistado, frente ao seu grau de escolaridade e de conhecimento/informação sobre essa infra-estrutura, bem como aos impactos econômicos, sociais e ambientais a ela associados. 
A regressão stepwise é um procedimento que insere e remove variáveis no modelo, em função do nível de confiança estabelecido, com o propósito de identificar um conjunto útil de sub-conjuntos de variáveis explicativas, dentre todas as analisadas, de modo a encontrar o melhor ajustamento. A inclusão ou exclusão é orientada com base nos valores da estatística "t" e no teste "F".

Supondo a necessidade de se construir um modelo baseado em $n$ observações independentes de uma variável dependente $Y$ e em um grande conjunto de $p$ potenciais variáveis explicativas $X_{1}, X_{2}, \ldots, X_{P}$, tem-se

$$
\hat{Y}_{k}=\hat{\beta}_{0}+\hat{\beta}_{1} X_{j 1}+\ldots+\hat{\beta}_{k} X_{j k}
$$

Para cada escolha de $k$, o modelo ideal escolhido deve minimizar a soma de quadrados do resíduo (SQR) entre todos os modelos com $k$ variáveis explicativas.

Na medida em que se deseja selecionar o melhor modelo explicativo com o menor número de variáveis, a regressão stepwise se apresenta como adequada. Segundo Foster \& Stine (1998), essa regressão pode utilizar três métodos: seleção para frente (forward selection), seleção para trás (backward selection) e seleção combinada (stepwise selection) para frente e para trás. $\mathrm{Na}$ forward selection as variáveis são adicionadas, uma por vez, e submetidas à análise de regressão. A cada passo da análise, uma da lista é selecionada com base na sua habilidade de explicar a variação em $\mathrm{Y}$, considerando o nível de confiança estabelecido. Seleções subseqüentes são feitas baseadas na habilidade relativa das demais variáveis em melhorar a explicação da variação não explicada pelas variáveis que já foram incluídas. Na backward selection, por sua vez, as variáveis são removidas, uma de cada vez, da lista de variáveis explicativas. Ela se inicia com todas as variáveis incluídas e elimina aquelas que não melhora a explicação provida pelas outras variáveis. A cada passo, a 
variável a ser removida é determinada pelo valor $\mathrm{p}$ para a estatística t. $\mathrm{Na}$ stepwise selection as variáveis explicativas são adicionadas ou removidas com base no teste $F$, sendo que, inicialmente o método processa a seleção para frente e, logo em seguida, realiza a seleção para trás até alcançar o melhor ajustamento do modelo, medido pelo coeficiente de determinação $R^{2}$ e $R^{2}$ ajustado.

Um aspecto importante da regressão stepwise é o seu uso em estudos de natureza exploratória, onde as relações de dependência ou de causa e efeito entre os fenômenos estudados não estão esclarecidas. Neste caso, conforme Abbad \& Torres (2002), o pesquisador não dispõe de uma teoria consistente sobre os eventos e, por isso, está interessado, inicialmente, em descrever os relacionamentos entre as variáveis e, não necessariamente, em os explicar. Assim, em estudos exploratórios a seleção da seqüência de entrada das variáveis explicativas é feita estatisticamente, sem um modelo teórico consistente a ser seguido, o que leva o pesquisador a elaborar um modelo teórico de investigação que inclua hipóteses sobre o relacionamento entre as variáveis sem, no entanto, estabelecer afirmações sobre a magnitude ou direção desses relacionamentos. Além disso, segundo os autores, este tipo de estudo não dispõe de apoio empírico para as hipóteses testadas. Citando Abbad (1999) ${ }^{12}$ afirmam que este tipo de estudo é comum em pesquisas na área de transferência de treinamento, cujo corpo teórico é disperso, cujos modelos de investigação são excessivamente parcimoniosos e onde há poucas informações sobre o relacionamento entre as variáveis.

No caso do presente estudo, será utilizada a seleção stepwise para avaliar o modelo estatístico proposto para a relação entre a importância atribuída à Hidrovia Tocantins-Araguaia e os possíveis impactos causados por ela nos principais municípios tocantinenses lindeiros aos rios Araguaia e

\footnotetext{
${ }^{12}$ ABBAD, G. Um modelo de avaliação do impacto do treinamento no trabalho - IMPACT. Brasília, 1999. Tese (Doutorado) - Universidade de Brasília. Não publicada.
} 
Tocantins. Nesse modelo, as variáveis consideradas estão apresentadas no Quadro 4.

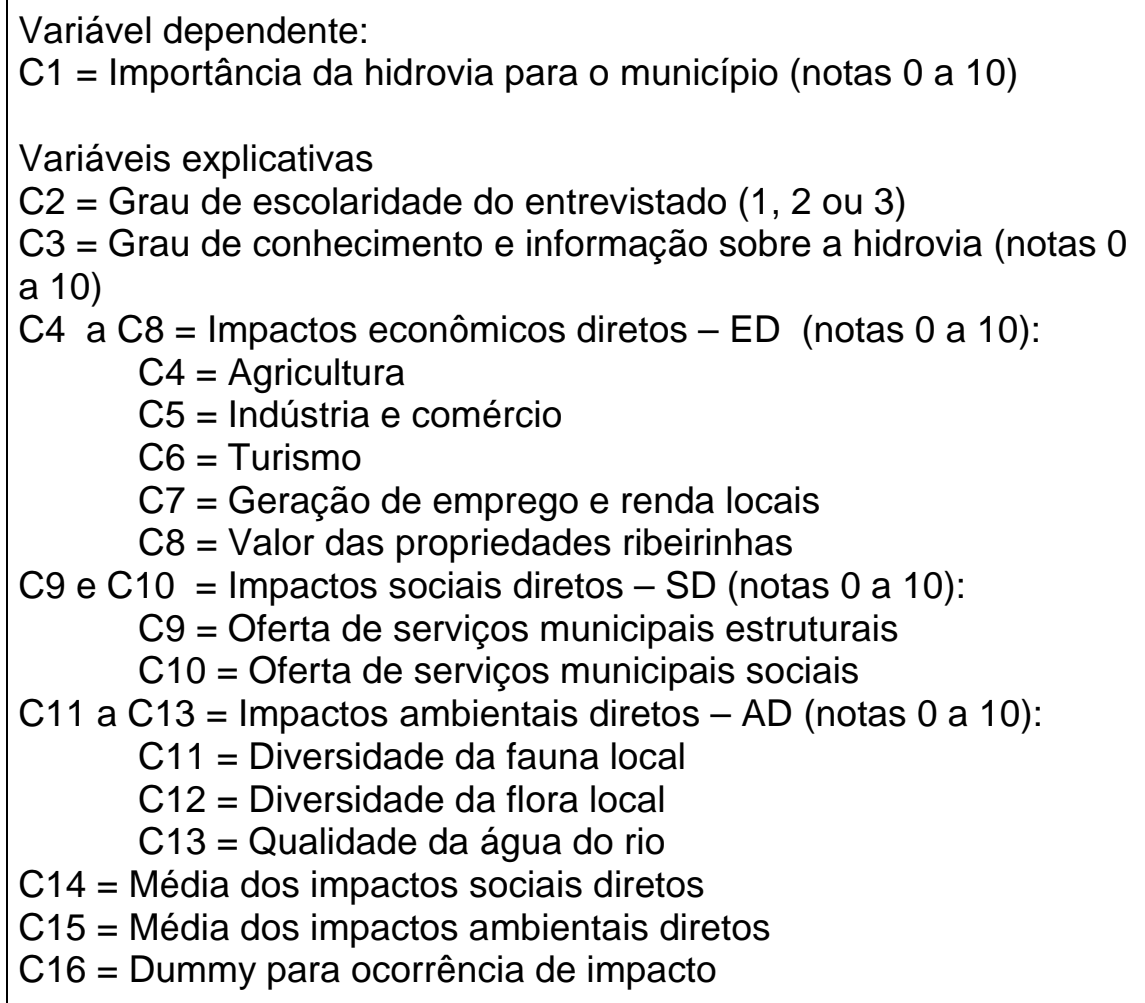

Quadro 4 - Variáveis consideradas no modelo estatístico sobre a importância da Hidrovia Tocantins-Araguaia para o município

Fonte: dados da pesquisa

\subsubsection{Grupo focal}

Uma vez que o presente estudo tem por objetivo captar as impressões dos agentes econômicos sobre a importância e impactos da Hidrovia Tocantins-Araguaia nos municípios lindeiros onde atuam, torna-se 
interessante conhecer não somente a impressão de cada entrevistado mas, quando possível, a de grupos que discutam e revelem suas opiniões sobre esse tema. Esse procedimento tem por sentido verificar a convergência entre as manifestações coletivas e individuais, favorecendo a identificação e análise de aspectos relevantes para o entendimento do assunto estudado. Nesse contexto é que se propõe a utilização do método de grupos focais para a realização, condução e análise da discussão dos grupos sobre a Hidrovia TocantinsAraguaia.

Grupo focal pode ser definido como um conjunto de indivíduos reunidos para discutir assuntos específicos utilizando, explicitamente, a interação pessoal para gerar informações. Segundo Barbour \& Kitzinger (1999), ao invés de utilizar apenas o questionamento individual através de entrevistas pessoais, os grupos focais reúnem indivíduos que são encorajados a falar entre si, a fazer perguntas e a trocar opiniões, experiências e pontos de vistas particulares. Esses grupos são ideais para explorar experiências pessoais, opiniões, desejos e preocupações. Gomes \& Barbosa (1999) assinalam que um grupo focal é um grupo de discussão informal, geralmente de tamanho reduzido, que permite obter informações de caráter qualitativo em profundidade. É uma técnica rápida e de baixo custo para avaliação e obtenção de dados e informações qualitativas, fornecendo ao pesquisador que o coordena uma grande riqueza de informações qualitativas sobre o tema discutido.

A finalidade básica de um grupo focal é possibilitar a interação entre os participantes, de modo que tenham condições de discutir assuntos específicos coordenados sob determinados interesses. Barbour \& Kitzinger (1999) afirmam que os grupos focais são bastante interessantes por permitirem que os participantes gerem suas próprias questões, organização e conceitos, bem como estabeleçam prioridades segundo seus próprios termos e vocabulários. Grupos focais também permitem que os pesquisadores examinem diferentes perspectivas das pessoas segundo sua atividade dentro da estrutura 
social vigente. O trabalho em grupo explora como as avaliações são articuladas, censuradas, opostas e modificadas através da interação social e como isso se relaciona com a comunicação e estrutura do grupo. Grupos focais são adequados para explorar como os pontos de vista são construídos e expressos, sendo fundamentais para examinar como o conhecimento, idéias, discursos, apresentações e mudanças lingüísticas operam dentro de um dado contexto cultural. Kitzinger (1994) $)^{13}$, citado por Barbour \& Kitzinger (1999), assinala que reunir as pessoas para trocar experiências partilhadas é, freqüentemente, muito produtivo. Gomes \& Barbosa (1999) observam que grupos focais são especialmente apropriados quando:

a) se deseja ampliar a compreensão a respeito de um projeto, programa ou serviço;

b) é importante conhecer preferências e necessidades de todos os envolvidos e/ou interessados sobre programas de atividades que estejam sendo planejados;

c) as preferências do consumidor precisam ser levadas em conta na implantação de serviços específicos ou no desenvolvimento de novos produtos;

d) existem grandes problemas de implementação como, por exemplo, em projetos complexos;

Segundo Gomes \& Barbosa (1999), as principais características de um grupo focal são:

\footnotetext{
${ }^{13}$ KITZINGER, J. The methodology of focus groups: the importance of interaction between research participants. Sociology of Health and Illness, v.16, n.1, p.103-121, 1994.
} 
a) compõe-se de 7 a 12 pessoas, para facilitar a interação entre os membros. Barbour \& Kitzinger (1999) ressaltam que, apesar da literatura sugerir esse tamanho como ideal, para alguns estudos sociológicos o número pode ser muito grande, o que leva alguns pesquisadores a trabalhar com grupos menores, em torno de 5 a 6 participantes;

b) utiliza reuniões cuja duração varia entre uma e duas horas;

c) geralmente apresenta baixo custo de realização;

d) concentra a conversação em torno de poucos tópicos (no máximo 5 assuntos) para possibilitar a discussão de todos os tópicos e estimular a revelação de informações sobre o tema discutido;

e) tem um moderador cuja função é coordenar, de maneira imparcial, os principais tópicos a serem discutidos de modo a realçar a conversação sobre os mesmos e a incentivar e garantir a participação de todos;

f) utiliza questões e respostas não estruturadas, de modo a incentivar a formação de novas idéias sobre o assunto que está sendo investigado;

g) aceita a presença de um observador externo silencioso, cuja função é captar reações dos participantes.

Outro aspecto relacionado aos grupos focais é a sua composição que pode ser heterogênea ou homogênea. No primeiro caso, os participantes têm diferentes formações, atuações e relações entre si e com o assunto discutido. No segundo, exibem maior proximidade. Barbour \& Kitzinger (1999) assinalam que existem opiniões e exemplos favoráveis tanto a uma quanto à outra composição, assim como ao fato dos participantes se conhecerem previamente ou não. Gomes \& Barbosa (1999), por outro lado, recomendam que os participantes sejam homogêneos, com níveis sócio-econômicos e culturais semelhantes, pois indivíduos muito diferentes podem inibir os comentários entre 
si. Não devem existir, segundo os autores, grandes diferenças de idade, posição social, posição hierárquica, conhecimento dos participantes e outras variáveis que possam influenciar na discussão, pois os participantes podem ajustar suas opiniões conforme a situação em que se encontrarem no grupo. Por isso, a definição do grupo alvo deve ser a mais específica possível.

Gomes \& Barbosa (1999) assinalam como limitações do método de grupos focais o formato flexível do grupo que o torna susceptível à condução imposta pelo moderador; o fato de não fornecer dados quantitativos, a dificuldade de generalização e/ou de análise de algumas informações obtidas, uma vez que os comentários são feitos dentro de determinado contexto; a impossibilidade de garantir total anonimato aos participantes; a dependência da seleção criteriosa dos participantes; e, a possibilidade de desvio ou de domínio da discussão por poucas pessoas.

A organização dos grupos focais deve estimular o comparecimento dos participantes de modo a garantir a realização e validade da reunião. Nesse contexto, Barbour \& Kitzinger (1999) afirmam que os pesquisadores devem recrutar mais participantes potenciais do que o necessário e procurar reembolsar suas despesas de deslocamento ou oferecer pagamentos pela participação, para estimular a freqüência. Além disso, devem escolher um local facilmente acessível e familiar às pessoas que desejam reunir. Os autores recomendam, também, que o local seja silencioso, confortável, reservado e protegido de interrupções. Gomes \& Barbosa (1999) assinalam que o evento deve durar de uma a duas horas e ser conduzido num local com certo grau de privacidade. Se houver observadores na reunião, os participantes devem ser informados de sua presença. O ambiente deve ser agradável, pois as pessoas devem sentir satisfação em participar do grupo, em fornecer informações e em contribuir para a realização dos trabalhos. 
Um aspecto fundamental no trabalho com grupos focais é a disponibilidade de recursos para gravação da discussão. Esse fato deve ser comunicado aos participantes, assegurando-lhes anonimato e uso exclusivo das gravações para as finalidades da pesquisa. Barbour \& Kitzinger (1999) afirmam que a gravação em fita cassete possibilita um valioso acesso à discussão, constituindo-se em memória adicional do pesquisador. A gravação em vídeo, por outro lado, pode tornar-se embaraçosa e inibir a participação, além do que pode provocar ilusões que dificultem a compreensão dos assuntos. Caso o pesquisador opte pela fita cassete, é interessante que tome nota de suas próprias impressões. Fitas cassete de discussões em grupo são, invariavelmente, mais difíceis de serem transcritas, porém, é interessante que sejam utilizadas para clarear a memória e as notas tomadas. Um dos desafios da transcrição é identificar as pessoas, por isso, torna-se interessante solicitar, ao início dos trabalhos, que cada participante fale o seu nome, como uma forma de checar a voz ao longo da fita. Do mesmo modo é adequado que o responsável pela transcrição esteja presente ao encontro do grupo e tome nota da seqüência de assuntos discutidos.

Conforme Gomes \& Barbosa (1999) o roteiro de discussão deve conter poucos itens permitindo flexibilidade e fluência na discussão, inclusive para temas não previstos, porém relevantes. As primeiras questões discutidas devem ser de caráter geral e de fácil abordagem, para permitir a participação imediata de todos. Em seguida, questões mais específicas e de caráter mais analítico podem ser apresentadas, além de outras que possam ter emergido das próprias respostas dadas anteriormente.

Gomes \& Barbosa (1999) recomendam atenção especial na formulação das perguntas a serem dirigidas ao grupo. Perguntas que não estimulem a discussão devem ser evitadas, como, por exemplo, aquelas cuja resposta seja sim ou não. Essas perguntas são unidimensionais e não estimulam discussões. Perguntas do tipo "por que" colocam as pessoas na 
defensiva, obrigando-as a ser politicamente corretas em questões controversas e polêmicas. Perguntas abertas são mais úteis aos objetivos dos grupos focais porque permitem aos participantes contar sua história e adicionar detalhes que podem resultar em descobertas interessantes.

$\mathrm{O}$ roteiro fornece a base para que o facilitador possa conduzir a reunião, explorar e investigar o assunto e fazer perguntas aos convidados. Segundo Barbour \& Kitzinger (1999) o facilitador precisa ser hábil para esclarecer questões ambíguas, estimular a discussão das questões até o fim, encorajar a participação de todos e assegurar que interesses e expectativas sejam perseguidos. Para isso, é crucial que tenha conhecimento prévio da linguagem, gestos e aspectos culturais dos participantes do grupo. Isso é interessante tanto para facilitar o trabalho do grupo quanto para interpretar os dados, posteriormente. Para Gomes \& Barbosa (1999) o facilitador deve esboçar a finalidade e o formato da discussão no começo da sessão. Deve ser informado aos participantes que a discussão é informal, que deve ter a participação de todos e que divergências de opiniões são bem vindas. Contudo, se a discussão for excessivamente ampla, o facilitador pode limitar as respostas. Ao perceber respostas incompletas ou irrelevantes, o facilitador deve buscar esclarecê-las. Para evitar o domínio da conversa por alguns indivíduos, o facilitador deve dirigir perguntas a quem se mostre relutante em falar. Ele deve estar atento para o fato de que quando uma idéia é aceita sem qualquer discussão geral ou discordância, pode está ocorrendo pressão do grupo.

A utilização de grupos focais para conhecer as impressões de um conjunto de indivíduos sobre determinado assunto favorece a obtenção de valiosas informações qualitativas. Diante disso, Barbour \& Kitzinger (1999) recomendam que a análise se baseie nas opiniões do grupo, sem deixar de considerar a importância das opiniões individuais. O pesquisador deve procurar distinguir as opiniões individuais semelhantes e contrárias às do grupo e o consenso construído e/ou expresso por ele. A análise envolve, no mínimo, 
extrair e comparar a discussão de temas similares e examinar como esses temas variam entre indivíduos e entre grupos.

Quanto ao processo de análise dos resultados da discussão, cabe anotar que alguns procedimentos devem ser observados no sentido de extrairse o máximo possível de informações do conteúdo. Em termos operacionais, Gomes \& Barbosa (1999) orientam que, após cada sessão, a equipe reúna as anotações do trabalho, os sumários e qualquer outro dado relevante para analisar tendências e padrões. Recomendam também a leitura de todos os resumos, simultaneamente, observando as tendências e padrões potenciais, opiniões solidamente mantidas ou freqüentemente expressas. Deve-se destacar as partes que correspondam às perguntas guias da discussão e realçar comentários que possam ser usados no relatório final. As perguntas devem ser analisadas separadamente sendo que, ao final da leitura de todas as respostas, deve ser redigido um sumário da discussão. Ao analisar os resultados a equipe deve considerar o significado das palavras utilizadas pelos participantes; as circunstâncias nas quais um comentário foi feito; o tom e a intensidade desses comentários; a causa das mudanças de opiniões durante as discussões; as respostas baseadas em experiências pessoais; e, as idéias preponderantes. A equipe deve considerar, também, o propósito do estudo e a informação necessária para a tomada de decisão. Os relatórios de grupos focais são, tipicamente, relatórios que destacam descobertas chaves, resumem a discussão e fornecem tendências, padrões ou descobertas, incluindo comentários selecionados. Segundo Frankland (1999) dado que toda análise é essencialmente comparativa, o processo de indexação do texto serve para facilitar essa comparação através da reunião de todos os dados sob tópicos particulares, com o sentido de tornar manejável o material obtido. Essa indexação geralmente observa os seguintes passos: 
a) o texto é lido como um todo para re-familiarizar o pesquisador com o seu conteúdo e permitir que se identifiquem palavras ou temas de interesse que foram recorrentes ao longo da discussão;

b) o texto é novamente lido e inicia-se o processo de vincular palavras-chave ou tópicos aos conteúdos. No inicio do processo as palavras ou os tópicos são gerais, sendo que o primeiro engloba todo o texto;

c) ao terminar essa primeira indexação, deve-se processar nova leitura com o objetivo de refinar o processo através da vinculação de novas palavraschave ou tópicos a trechos mais específicos do conteúdo, o que revela um processo cíclico de indexação.

Ao final da indexação o pesquisador tem facilitada através das palavras-chave ou dos tópicos, a rápida identificação e localização de trechos ou assuntos que sejam do seu interesse naquele momento, sem a necessidade de uma re-leitura de todo o texto.

Em função de suas características e potenciais, grupos focais podem ser utilizados em diferentes tipos de estudo. Pizzol (2002) utilizou o método de grupos focais para identificar a existência de diferentes sistemas de produção de café na região de Marília (SP). Os comentários dos grupos focais foram tratados sob análise indutiva com o objetivo de derivar proposições que se aplicassem de forma geral a todos os dados. Essa análise permitiu ao autor a geração de hipóteses sobre os sistemas de produção que, em seguida foram submetidas à análise discriminante de forma a completar a tipificação desses sistemas. World Bank (2000) aplicou grupos focais, dentre outros métodos, para avaliar a pobreza no Brasil considerando bem-estar e tendências na variação temporal do bem-estar através de questões relativas à segurança, risco, vulnerabilidade, coesão social, exclusão social, oportunidade e mobilidade, crime e conflito. O autor focalizou, também, problemas e prioridades, instituições segundo a confiança e avaliação da efetividade das diversas 
instituições governamentais, não-governamentais e de mercado e possíveis mudanças nas relações de gênero nas famílias e comunidades. A análise efetuada procurou destacar os resultados comuns a grupos e comunidades, as variações entre comunidades e entre grupos, e os resultados singulares de grupos em localidades específicas. WWF-Brasil (2001) em pesquisa sobre a Amazônia brasileira, utilizou grupos focais para identificar a percepção dos problemas ambientais por colonos assentados, extrativistas, madeireiros e ribeirinhos. Foram realizados, ao todo, quatro grupos focais que reuniram extrativistas e colonos assentados em Rondônia, ribeirinhos e madeireiros no Pará. No total participaram 57 indivíduos "economicamente ativos", especialmente chefes de família. Através da abordagem qualitativa, o autor buscou detectar a percepção individual sobre as relações entre sua atividade econômica e o uso sustentável dos recursos naturais; compreender seus valores, compromissos e parcerias, sobretudo com o WWF-Brasil; e, identificar as prioridades atuais dos participantes.

A seguir, no Capítulo 6, são analisados e discutidos os resultados de campo, referentes às entrevistas individuais e as observações feitas pelo grupo focal referente à Hidrovia Tocantins-Araguaia. 


\section{RESULTADOS E DISCUSSÃO}

O objetivo deste Capítulo é apresentar e discutir os resultados obtidos a partir das informações levantadas individual e coletivamente. No caso das entrevistas individuais procurou-se qualificar as impressões dos entrevistados sobre a presença da Hidrovia em seu município, sobre os possíveis serviços que ela pode prover, sobre sua ocorrência, sentido e intensidade de impactos e, também, sobre sua importância geral e inclusão nos projetos públicos ou privados locais. Através da análise econométrica dessas informações, buscou-se avaliar a relação entre os impactos econômicos, sociais e ambientais e a importância atribuída à Hidrovia, utilizando um método de regressão linear do tipo stepwise (passo-à-passo). No caso do grupo focal realizado, procurou-se a partir da discussão comum, identificar melhor aspectos qualitativos sobre a influência e a importância da Hidrovia Tocantins-Araguaia tanto para o próprio Estado, quanto para a região onde ela se insere.

\subsection{Entrevistas individuais: primeiras evidências de campo}

A análise das primeiras evidências de campo exige, inicialmente, que se faça uma breve caracterização do trabalho de levantamento de dados e do tamanho da amostra. Em seguida, as informações, propriamente ditas são analisadas. 


\subsubsection{Considerações sobre o levantamento de dados}

Durante os meses de fevereiro e março de 2004, foram entrevistadas 24 pessoas em 7 diferentes municípios tocantinenses lindeiros aos rios Araguaia e Tocantins. Esses rios servem de base para duas hidrovias de mesmo nome que, por sua vez, constituem a Hidrovia Tocantins-Araguaia. Os municípios onde ocorreram as entrevistas foram Xambioá, Araguanã e Couto Magalhães, às margens do rio Araguaia e Lajeado, Miracema, Palmas e Porto Nacional às margens do Tocantins. A Figura 8 assinala a distribuição espacial dos municípios visitados durante o levantamento. 


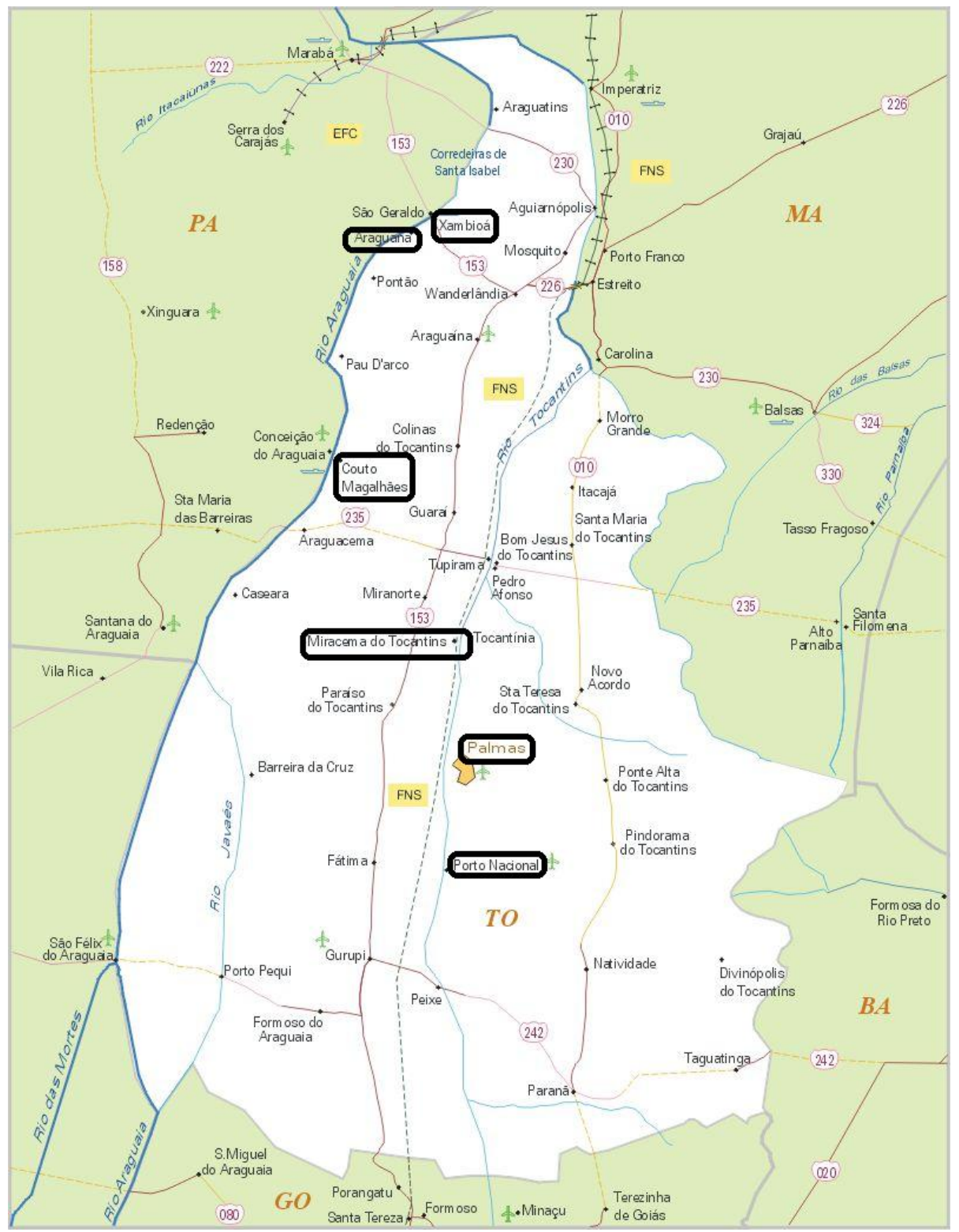

Figura 8 - Municípios visitados no levantamento de campo, Hidrovia Tocantins-Araguaia, fev.-mar./2004, Estado do Tocantins

Fonte: dados da pesquisa 
As entrevistas com os agentes econômicos além de permitir o levantamento das informações possibilitaram, também, verificar in loco as condições físicas da Hidrovia nos municípios. É importante ressaltar que o período de entrevistas coincidiu com um período de chuvas intensas na região, possibilitando a visualização dos rios em seu maior volume d'água quando, teoricamente, apresentam melhores condições de navegabilidade. Contudo, diante da inexistência ou deterioração da infra-estrutura operacional instalada nos municípios, fica evidente que a Hidrovia Tocantins-Araguaia ainda é apenas um projeto. Como exemplo, pode ser citada a estrutura instalada em Xambioá em 1998 e, atualmente, completamente abandonada, conforme ilustram as Figuras 9 e 10 mostrando, respectivamente, o porto de carga e descarga e o galpão de equipamentos para transbordo de carga à granel, completamente deteriorados.

Outra evidência de que a Hidrovia Tocantins-Araguaia está longe de ser implantada é o fato das chatas (4 graneleiras e 1 tanque-combustível) que fizeram três viagens no rio Araguaia, entre 1998 e 2000, com cargas originadas no Mato Grosso segundo registros do Ministério dos Transportes e afirmação pessoal do marinheiro que conduziu os comboios, estarem atracadas desde então, às margens do Araguaia, no município de Couto Magalhães, conforme apresenta a Figura 11. Note-se que, após essa data, nenhuma outra viagem foi realizada. Segundo depoimentos locais, a manutenção da sinalização postada ao longo do rio é feita por equipe da AHITAR e a das chatas por sua proprietária, a Companhia Araguaiana de Navegação Fluvial Ltda. 


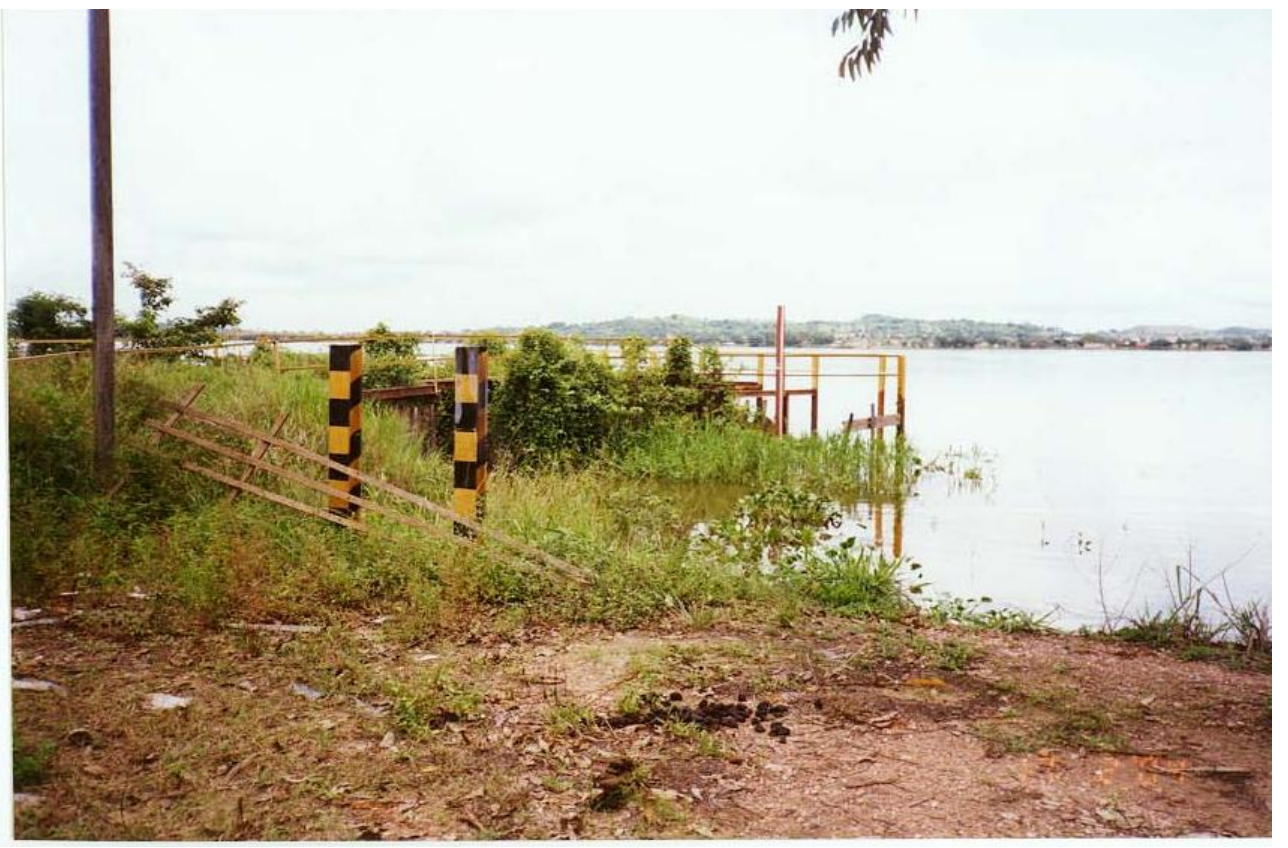

Figura 9 - Porto para embarque de carga, rio Araguaia, Município de Xambioá (TO), fev/2004

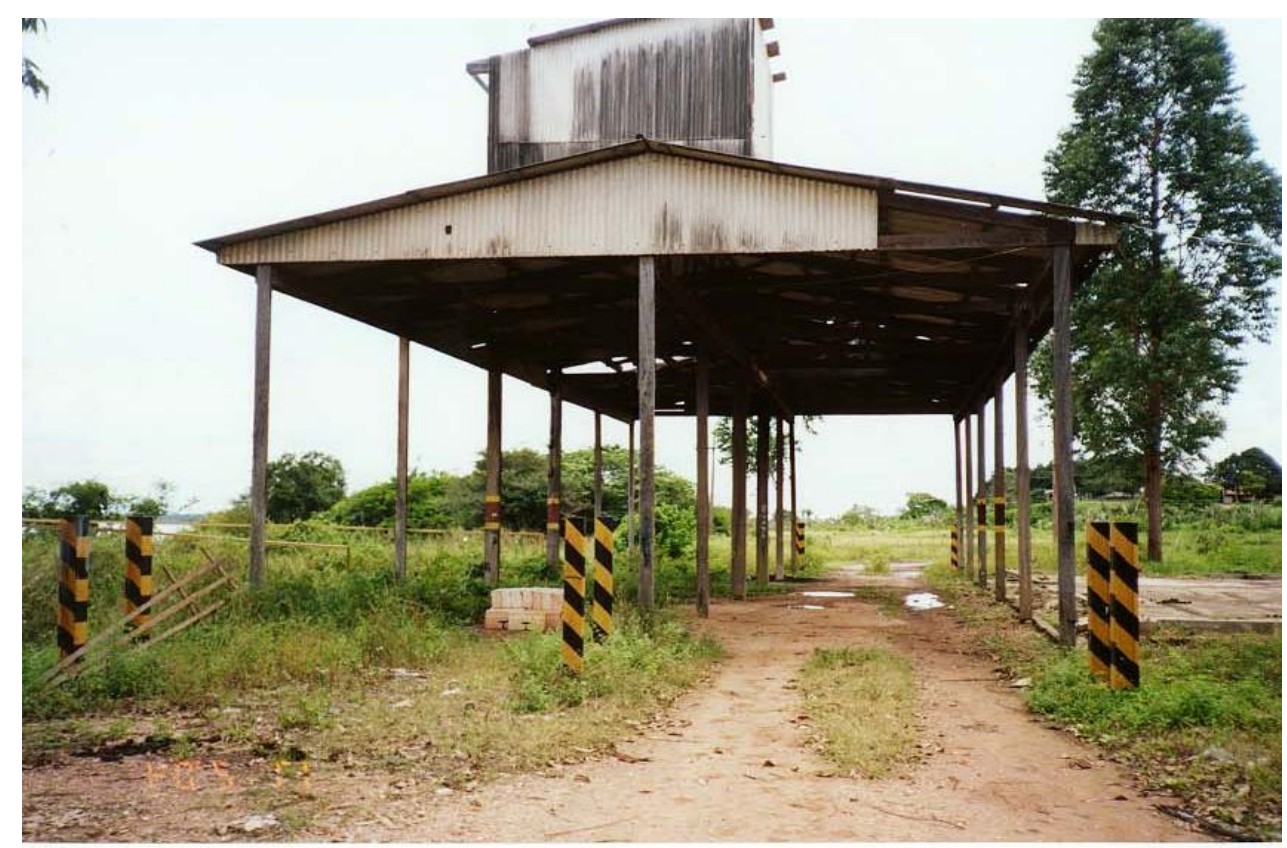

Figura 10 - Galpão de equipamentos de transbordo de carga a granel, rio Araguaia, Município de Xambioá (TO), fev/2004 


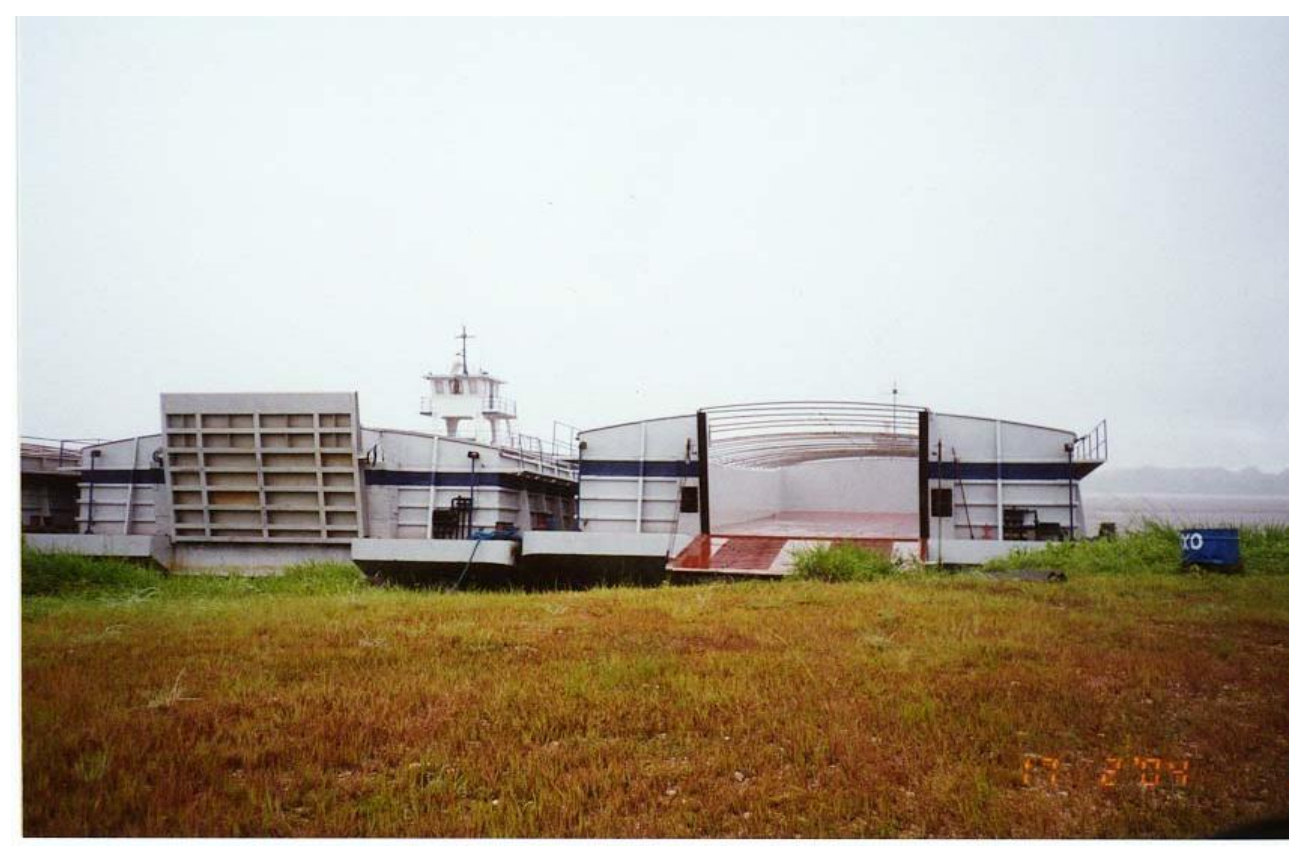

Figura 11 - Chatas graneleiras e tanque-combustível atracadas no rio Araguaia, Município de Couto Magalhães (TO), fev/2004

A situação da Hidrovia Araguaia, verificada durante as entrevistas e ilustradas pelas imagens, contrasta com as informações de Brasil (2003a) que afirma que o Porto de Xambioá, cuja finalidade é integrar o modal hidroviário ao rodoviário para o transporte de soja no corredor Tocantins-Araguaia disponha de cais com acostamento para comboios de até $120 \mathrm{~m}$ de comprimento e $2 \mathrm{~m}$ de profundidade, possua armazém graneleiro com capacidade de $3.000 \mathrm{t} \mathrm{e}$ movimentação de grãos feita diretamente dos caminhões por sugador com capacidade de 90 toneladas/hora. Na realidade, essa estrutura está deteriorada e não tem condição de uso.

No rio Tocantins, por sua vez, sabe-se que a navegação é dificultada pelos desníveis naturais das cachoeiras que, segundo o projeto da hidrovia, serão vencidos pela formação de lagos artificiais decorrentes da construção de 7 usinas hidrelétricas ao longo do Tocantins. Essa estruturação energética 
favorecerá a consolidação da hidrovia desde que seja acompanhada de eclusas que possibilitem o tráfego dos comboios. Todavia, apesar da Usina Luís Eduardo Magalhães, no Município de Lajeado, estar operando desde 2002, sua eclusa encontra-se apenas na fase inicial da escavação. Outro problema é que os projetos das usinas à jusante de Lajeado têm enfrentado problemas de licenciamento ambiental e estão embargados pelo Ministério Público. Essa situação gera o distanciamento dos agentes econômicos em relação à proposta da Hidrovia Tocantins-Araguaia e dúvidas sobre sua consolidação. Como reflexo, dificulta a inserção dessa infra-estrutura nos projetos públicos ou privados desses agentes, conforme as declarações captadas nas entrevistas e analisadas mais adiante.

\subsubsection{Considerações sobre o tamanho da amostra}

O reduzido número de observações que compõem a amostra sobre a Hidrovia Tocantins-Araguaia é conseqüência tanto dos procedimentos adotados para o levantamento de dados, quanto das características particulares dos indivíduos, instituições e municípios escolhidos.

A grande dimensão do projeto da Hidrovia Tocantins-Araguaia e o fato dela não estar fisicamente estruturada prejudicou a reflexão dos agentes econômicos sobre seus diferentes impactos e importância para os municípios onde atuam. Isso dificultou a identificação de indivíduos que tivessem algum conhecimento e opinião a respeito do projeto. Diante disso, foram estabelecidos alguns cuidados para encontrar opiniões válidas para o estudo e, sobretudo, para evitar sua indução pela tentativa de explicar ao entrevistado o significado dessa infra-estrutura ou seus possíveis impactos. Contudo, o estabelecimento de tais cuidados se refletiu na consecução de apenas 24 entrevistas. Por outro lado, ainda que de certa forma tenham prejudicado a quantidade de 
observações, as precauções foram essenciais para elevar a qualidade das informações obtidas junto aos entrevistados.

Considerando que o estudo buscava captar as impressões dos possíveis usuários sobre os impactos econômicos, sociais e ambientais da Hidrovia Tocantins-Araguaia nos seus municípios tocantinenses, evidenciou-se a necessidade de alcançar, preferencialmente, aqueles que tivessem conhecimento e informação sobre o tema. Para isso, no início da entrevista, foram inseridas duas questões cujo objetivo era identificar o grau de entendimento e de conhecimento sobre a hidrovia. Essas questões funcionaram como um filtro eficiente, impedindo a realização de algumas entrevistas pelo fato dos indivíduos mostrarem-se ou declararem-se desconhecedores do assunto. Esse desconhecimento foi observado junto a representantes de todos os setores de interesse à pesquisa, inclusive o público. Em dois municípios, um às margens do Araguaia e outro do Tocantins, os secretários indicados pelos prefeitos para responder às entrevistas alegaram não ter informações adequadas para responder às perguntas. Em outra localidade, dois vereadores se recusaram a conceder a entrevista sob o mesmo argumento. Vale à pena ressaltar que a inexistência física e a falta de informações são responsáveis por essa situação de distanciamento dos agentes econômicos em relação à idéia da hidrovia.

Uma outra preocupação do levantamento de campo sobre a Hidrovia Tocantins-Araguaia foi buscar, nos municípios, apenas indivíduos que exercessem funções de responsabilidade em instituições, empresas, entidades ou organizações cujas atividades fossem, de alguma forma, diretamente relacionadas com aquela infra-estrutura. Dessa forma, as impressões captadas incluiriam as visões institucionais ou empresariais sobre a questão. Diante disso, foram procurados prefeitos, secretários, diretores ou coordenadores de instituições públicas municipais ou estaduais; gerentes ou administradores de empresas privadas de mineração, produção de insumos agropecuários ou de 
alimentos e agências de financiamento; presidentes, superintendentes ou diretores de entidades do setor industrial e comercial; e, diretores ou coordenadores de organizações de fiscalização de atividades ambientais e proteção ao meio ambiente.

Ainda que todos os municípios às margens dos rios Araguaia e Tocantins servissem de espaço interessante ao estudo da hidrovia, foram selecionados apenas aqueles que, além do trânsito hidroviário dos comboios tivessem, também, estrutura portuária que possibilitasse o contato direto com as atividades hidroviárias. Acreditava-se que, nessas localidades, os agentes econômicos estariam mais sensibilizados quanto à consecução e implicações dessa infra-estrutura, facilitando a captação de suas impressões. Assim é que, no Araguaia, os municípios de Xambioá, Araguanã e Couto Magalhães foram escolhidos por abrigarem estrutura portuária utilizada experimentalmente entre 1998 e 2000 e abandonada depois disso. No Tocantins, o município de Lajeado foi escolhido por recepcionar a primeira eclusa da hidrovia, em construção na Usina Hidrelétrica Luis Eduardo Magalhães. Por sua vez, Miracema, Palmas e Porto Nacional foram escolhidos por abrigarem projetos de futuros terminais portuários e também por serem considerados importantes pontos estaduais de distribuição de produtos e insumos. Contudo, à exceção da capital do Estado, Palmas, os demais municípios são de porte populacional e econômico muito reduzido, como se pode verificar pela Tabela 14, o que se refletiu na dificuldade de identificar indivíduos habilitados à entrevista. Adicionalmente, as cidades têm uma forte orientação política e econômica para o transporte rodoviário, colocando em plano inferior o hidroviário. O abandono e/ou a inexistência da estrutura da hidrovia colaboram para essa situação. Palmas, por sua vez, um município com apenas 15 anos de idade na época da pesquisa, representa o centro estadual de decisões políticas e tem, hipoteticamente, seu ambiente municipal sobre possível influência da hidrovia. Porém, lá não foi menor a dificuldade em angariar opiniões sobre essa infra-estrutura, uma vez que o 
município também foi criado sobre um contexto expressivamente rodoviário. O rio Tocantins, nesse município, é identificado com o lago da Usina Luís Eduardo Magalhães e visto, essencialmente, como uma possibilidade turística ao longo da orla municipal, sendo dissociado da possibilidade de transporte hidroviário.

De maneira geral, os entrevistados na pesquisa sobre a Hidrovia Tocantins-Araguaia deveriam ter conhecimentos específicos sobre essa infraestrutura, exercer função de comando e representação em suas instituições ou empresas e estar localizados em municípios com particular importância para a hidrovia. Essa conjunção de restrições a que o trabalho de campo foi submetido pode justificar o tamanho reduzido da amostra obtida. Uma alternativa para aumentar a amostra seria flexibilizar alguma dessas restrições como, por exemplo, permitir que outros municípios tocantinenses, ao longo das hidrovias Araguaia ou Tocantins, fossem incluídos mesmo que estes recebessem apenas passagem dos comboios. Nesse contexto, seria esperado que, só pelo fato dessa passagem se realizar, algum efeito ocorreria sobre a economia, sociedade ou ambiente locais. Ao todo isso significaria que mais cinco pequenos municípios poderiam ser incluídos na amostra. Outra possibilidade seria incluir entrevistados cujo conhecimento sobre o tema fosse apenas superficial. Uma terceira opção seria captar mais indivíduos de uma mesma instituição, empresa ou organização, ou então buscar organizações cujas atividades mantivessem alguma distância em relação aos possíveis serviços prestados pela hidrovia. É preciso ter claro que, ao viabilizar o aumento do número de observações na amostra, essas alternativas poderiam implicar perda de qualidade das informações de campo por estarem englobando municípios, entrevistados e organizações com uma relação mais distante com a Hidrovia Tocantins-Araguaia. 
Tabela 14. Características demográficas, sociais e econômicas dos principais municípios na área de influência da Hidrovia Tocantins-Araguaia, Estado do Tocantins, Brasil, 2000

\begin{tabular}{|c|c|c|c|c|c|c|}
\hline Descrição & $\begin{array}{l}\text { COUTO } \\
\text { MAGALHÃES }\end{array}$ & XAMBIOÁ & LAJEADO & $\begin{array}{l}\text { MIRACEMA } \\
\text { DO TO }\end{array}$ & PALMAS & $\begin{array}{l}\text { PORTO } \\
\text { NACIONAL }\end{array}$ \\
\hline Área Total (km2) & 1586 & 1382 & 300 & 2656 & 2465 & 4446 \\
\hline \multicolumn{7}{|l|}{ População } \\
\hline Residentes & 4335 & 12137 & 2344 & 24444 & 137355 & 44991 \\
\hline homens & 2320 & 6142 & 1279 & 12978 & 68735 & 22479 \\
\hline mulheres & 2015 & 5995 & 1065 & 11466 & 68620 & 22512 \\
\hline \multicolumn{7}{|l|}{ Habitação } \\
\hline Domicílios & 1080 & 2816 & 562 & 5887 & 35047 & 10544 \\
\hline .esgoto sanitário & 0 & 1 & 0 & 19 & 5984 & 29 \\
\hline .água encanada & 490 & 1596 & 371 & 4724 & 32458 & 8375 \\
\hline .lixo coletado & 162 & 1500 & 314 & 4032 & 32552 & 7391 \\
\hline \multicolumn{7}{|l|}{ Saúde } \\
\hline Hospitais & 1 & 1 & 0 & 1 & 3 & 1 \\
\hline Leitos hospital & 30 & 30 & 0 & 71 & 195 & 76 \\
\hline \multicolumn{7}{|l|}{ Ensino (estab.) } \\
\hline Fundamental & 21 & 23 & 3 & 37 & 59 & 78 \\
\hline Médio & 1 & 3 & 1 & 3 & 20 & 11 \\
\hline \multicolumn{7}{|l|}{ Economia } \\
\hline FPM (R\$) & 852.893 & 1.394 .816 & 852.893 & 1.502 .110 & 51.515 .967 & 2.575 .045 \\
\hline ITR (R\$) & 9.421 & 15.726 & 3.622 & 27.574 & 11.974 & 37.348 \\
\hline
\end{tabular}

Fonte: IBGE (2003)

\subsubsection{Considerações sobre os entrevistados}

As características da amostra de entrevistados na pesquisa encontram-se na Tabela 15. O exame dessa tabela revela que, de modo geral, foram entrevistados representantes do poder público, da iniciativa privada, de entidades de classe e de organismos não governamentais relacionados ao meio ambiente. A amostragem foi intencional, no sentido de contatar indivíduos que tivessem conhecimento e informação sobre a presença da Hidrovia Tocantins- 
Araguaia no seu município e, também, que representassem instituições públicas, privadas, classistas ou ambientais relacionadas direta ou indiretamente com a hidrovia. Essa intencionalidade acabou por se refletir no número reduzido de entrevistas por município, sendo que nos de menor porte econômico foi difícil encontrar quem tivesse condições de conversar sobre o assunto. Foram várias as situações em que a entrevista foi impossibilitada pelo fato do entrevistado não ter conhecimento ou informações sobre a hidrovia ou por confundi-la com a Ferrovia Norte-Sul. Palmas, capital do Estado, concentra parcela mais expressiva de instituições e indivíduos relacionados com a Hidrovia Tocantins-Araguaia e, por isso, possibilitou um maior número de entrevistas (10), equivalente a $42 \%$ do total.

Dentre as instituições públicas representadas na amostra estão prefeituras, câmaras e secretarias municipais, bem como secretarias e departamentos estaduais. No âmbito privado, representam-se empresas de alimentação, navegação e mineração, além de agentes financeiros. Dentre as entidades de classe estão a Federação das Industrias do Tocantins e algumas associações comerciais e industriais municipais. Como organismos vinculados ao meio ambiente estão o Instituto Natureza do Tocantins (NATURATINS), o Ministério Público Estadual - Promotoria Ambiental e a organização nãogovernamental Associação de Consumidores do Meio Ambiente e de Produtores de Alimento na Amazônia (GAIA).

Quanto aos entrevistados, observa-se que, na totalidade, exercem ou exerceram funções de comando ou representação em suas organizações. Isso é importante no sentido de que sua visão pessoal e expectativas incluem as diretivas, os interesses e as políticas organizacionais. Entretanto, é preciso considerar que essa interação indivíduo-instituição pode ter introduzido algum viés de auto-interesse nos dados levantados, refletindo-se na super ou na subestimação de impressões ou expectativas individuais. Outro aspecto de realce na amostra é que a maioria detém escolaridade de nível médio ou 
superior, o que favorece a compreensão pelo entrevistado de aspectos técnicos ou específicos relacionados à Hidrovia Tocantins-Araguaia e interessantes a esta pesquisa.

\subsubsection{Impressões sobre a prestação de serviços ao município}

Antes de captar as impressões sobre os possíveis serviços prestados pela Hidrovia Tocantins-Araguaia ao município, como demonstra a Tabela 16, foi solicitado ao entrevistado que declarasse, numa escala de zero a 10, seu grau de conhecimento e informação sobre essa via de transporte. Foram declarados graus entre 2 e 9 com média, moda e mediana iguais a 5, o que pode ser entendido como um nível médio de conhecimento sobre o tema. Analisando-se separadamente as amostras relativas às Hidrovias Araguaia e Tocantins percebe-se semelhança nos resultados. É interessante notar que o grau 9, declarado por dois entrevistados, explica-se por se tratar de um engenheiro, em Palmas, com vários anos de trabalho na Hidrovia Tietê-Paraná, em São Paulo e de um vereador em Couto Magalhães que também é marinheiro e o responsável pela manutenção das chatas atracadas no Araguaia, tendo sido condutor dos comboios nas três únicas viagens realizadas naquele rio, entre 1998 e 2000. 
Tabela 15. Identificação da amostra de entrevistados sobre a Hidrovia TocantinsAraguaia nos diferentes municípios tocantinenses onde atuam

\begin{tabular}{|c|c|c|c|c|}
\hline \multirow{2}{*}{$x^{2}$} & \multirow{2}{*}{ Município } & \multicolumn{3}{|c|}{ Características do Entrevistado } \\
\hline & & Instituição/Empresa & Função/Atividade & $\begin{array}{l}\text { Grau } \\
\text { Escolar }\end{array}$ \\
\hline 1 & Xambioá & Secretaria Municipal de Administraçãc & Secretário Municipal & 2 \\
\hline 2 & Xambioá & Mineração Vale do Araguaia Ltda & Gerente Comercial & 3 \\
\hline 3 & Araguanã & Araguanã Ind.Com.Alim.Ltda & Proprietário / Administrador & 2 \\
\hline 4 & $\begin{array}{l}\text { Araguanã } \\
\text { Couto }\end{array}$ & Prefeitura Municipal & Assistente de Gabinete & 2 \\
\hline 5 & $\begin{array}{l}\text { Magalhães } \\
\text { Couto }\end{array}$ & Cia Araguaiana de Navegação Fluvial & Assistente Geral & 1 \\
\hline 6 & Magalhães & Câmara Municipal / Cia Araguaiana & Vereador / Marinheiro & 2 \\
\hline 7 & Lajeado & Prefeitura Municipal & Diretor de Finanças & 2 \\
\hline 8 & Lajeado & Associação Comercial e Industrial & Presidente & 1 \\
\hline 9 & Miracema & Prefeitura Municipal & Vice-Prefeita & 2 \\
\hline 10 & Miracema & Câmara Municipal & Vereador & 3 \\
\hline 11 & Miracema & Associação Comercial e Industrial & Ex-Presidente & 2 \\
\hline 12 & Palmas & Ministério Público Estadual & Promotor Público Ambiental & 3 \\
\hline 13 & Palmas & Dep. Estradas do TO / GAIA (ONG) & Coord. de Meio Ambiente & 3 \\
\hline 14 & Palmas & Inst. Euvaldo Lodi / Fed. Ind. do TO & Superintendente IEL & 3 \\
\hline 15 & Palmas & Secret. Estado de Ind. e Comércio & Diretor de Ind. e Comércio & 3 \\
\hline 16 & Palmas & Banco do Brasil AS & Gerente de Mercado & 3 \\
\hline 17 & Palmas & Secret. Est. Planej. e Meio Ambiente & Diretor de Pesquisa & 3 \\
\hline 18 & Palmas & NATURATINS & Coord. Proj. de Grande Porte & 3 \\
\hline 19 & Palmas & Banco da Amazônia SA & Gerente Regional & 3 \\
\hline 20 & Palmas & Associação Comercial e Industrial & Presidente & 3 \\
\hline 21 & Palmas & Secret. Munic. de Ind. e Comércio & Secretário Municipal & 3 \\
\hline 22 & Porto Nacional & Prefeit. Munic. / Câmara Municipal & $\begin{array}{l}\text { Secret. de Admin./ Vereador } \\
\text { Ex-Presidente / Deputado }\end{array}$ & 3 \\
\hline 23 & Porto Nacional & Associação Comercial e Industrial & Estadual & 2 \\
\hline 24 & Porto Nacional & Mineração Tocantins Ltda & Gerente Comercial & 3 \\
\hline
\end{tabular}

Fonte: dados da pesquisa 
No que respeita à Hidrovia Tocantins-Araguaia, a maioria dos entrevistados declarou que a implantação nos diferentes municípios encontrase no estágio inicial e que não existe estrutura operacional disponível tal como porto para carga-descarga, equipamento para transbordo ou depósito para armazenamento de carga. Essa situação foi constatada pessoalmente ao longo das visitas aos municípios. A despeito disso, foi solicitado aos entrevistados que, numa escala de zero a 10, expressassem suas impressões sobre a importância de quatro serviços atribuídos à hidrovia caso estivessem disponíveis ao município: transporte de mercadorias (insumos e produtos); transporte de pessoas; transporte de animais; e, serviços de turismo. Entre os quatro, o transporte de mercadorias e os serviços de turismo foram considerados os de maior importância, conforme revelam médias 7,9 e 8, modas 10 para ambos e medianas 8 e 9, respectivamente. Em termos de Hidrovias Araguaia e Tocantins, isoladas, os dados evidenciam impressões semelhantes. Os resultados refletem uma elevada importância da hidrovia no contexto de transporte de insumos e produtos no município, mesmo considerando a disponibilidade da atual malha rodoviária estadual que é bastante capilar e de boa qualidade. Essa condição de malha viária permite o transporte de pessoas e animais em menor prazo de tempo, explicando a menor importância desses serviços no caso da hidrovia. No caso dos serviços de turismo, os dados refletem a expectativa dos entrevistados no incremento das atividades eco-turísticas em suas regiões. 
Tabela 16. Considerações sobre os serviços prestados pela Hidrovia Tocantins-Araguaia

\begin{tabular}{|c|c|c|c|c|c|c|c|}
\hline \multirow{3}{*}{ - Município } & \multirow{3}{*}{$\begin{array}{c}\text { Grau de } \\
\text { conhecimento } \\
\text { informação do } \\
\text { sobre a HTA }\end{array}$} & \multicolumn{6}{|c|}{ Hidrovia no Município } \\
\hline & & \multirow{2}{*}{$\begin{array}{c}\text { Estágio de } \\
\text { implantação } \\
\text { (a) }\end{array}$} & \multirow{2}{*}{$\begin{array}{c}\text { Estrutura } \\
\text { operacional } \\
\text { disponível (b) }\end{array}$} & \multicolumn{4}{|c|}{ Importância dos serviços (notas de 0 a 10) } \\
\hline & & & & $\begin{array}{l}\text { Transporte } \\
\text { mercadorias }\end{array}$ & $\begin{array}{l}\text { Transporte de } \\
\text { pessoas }\end{array}$ & $\begin{array}{l}\text { Transporte de } \\
\text { animais }\end{array}$ & $\begin{array}{c}\text { Serviços de } \\
\text { Turismo }\end{array}$ \\
\hline \multicolumn{8}{|c|}{ Hidrovia Araguaia $(n=6)$} \\
\hline Moda & - & 1 & 1 & 10 & 10 & 0 & 0 \\
\hline Mediana & 5,5 & 1 & 1 & 10 & 7 & 1 & 7 \\
\hline Média & 5,7 & & & 8,0 & 5,7 & 3,3 & 5,7 \\
\hline \multicolumn{8}{|c|}{ Hidrovia Tocantins $(n=18)$} \\
\hline Moda & 5 & 1 & 4 & 8 & 6 & 6 & 10 \\
\hline Mediana & 5 & 1 & 4 & 8 & 5 & 6 & 9 \\
\hline Média & 4,8 & & & 7,9 & 4,8 & 5,6 & 8,7 \\
\hline \multicolumn{8}{|c|}{ Hidrovia Tocantins-Araguaia $(n=24)$} \\
\hline Moda & 5 & 1 & 4 & 10 & 5 & 6,0 & 10 \\
\hline Mediana & 5 & 1 & 4 & 8 & 5 & 5,5 & 9 \\
\hline Média & 5,0 & & & 7,9 & 5,0 & 5,0 & 8,0 \\
\hline
\end{tabular}

Fonte: dados da pesquisa

(a) inicial 1; intermediário 2; final 3; não existe 4; não sabe 5

(b) porto 1; equipamento $\mathrm{p} /$ transbordo 2; depósito p/ carga 3; não existe 4; não sabe informar 5 


\subsubsection{Impressões sobre os impactos no município}

Admitindo que a Hidrovia Tocantins-Araguaia tenha impactos sobre diferentes setores e aspectos econômicos, sociais e ambientais nos municípios que ela tange, buscou-se captar as expectativas dos entrevistados quanto à ocorrência, sentido e intensidade de alguns desses impactos. A Tabela 17 revela essas expectativas. Os impactos econômicos são avaliados sobre agricultura, indústria e comércio, turismo, emprego e renda, valor das propriedades ribeirinhas, oportunidades locais, arrecadação e gastos públicos. Entre os sociais analisam-se os reflexos sobre serviços públicos estruturais e sociais, integração com regiões e comunidades exteriores, atividades culturais e espaços para lazer. Na questão ambiental investigam-se expectativas sobre variedade da fauna e da flora locais, ocorrência de cheias e enchentes e qualidade da água do rio. Nota-se que, para a amostra como um todo, há expectativa de que a implantação e a operação da hidrovia realmente provoquem impacto econômico ou social, direto ou indireto. Apenas sobre o meio ambiente notam-se manifestações mais expressivas sobre a possibilidade de não haver reflexos.

No que respeita ao sentido dos impactos a maioria declara esperar aumento das atividades econômicas e das ações sociais do município, revelando uma expectativa favorável sobre a hidrovia. No caso dos impactos ambientais, a diminuição da variedade da fauna, da flora e da qualidade da água do rio é assinalada pela maioria dos entrevistados, refletindo a expectativa de perda do valor ambiental pela implantação e operação da hidrovia. Nesse aspecto ambiental, o fator positivo é a expectativa de que ela provoque a diminuição da ocorrência de cheias e enchentes nos municípios que são muito prejudicados por esse fenômeno no período chuvoso intenso entre dezembro e março. Aliás, na época da realização das entrevistas, os municípios lindeiros ao rio Araguaia estavam em estado de alerta quanto ao nível do rio sendo 
inundados por suas águas pouco tempo depois. Essas observações aparentemente não diferem quando se consideram, separadamente, as hidrovias Araguaia ou Tocantins, conforme demonstra a Tabela 18.

Tabela 17. Expectativas dos entrevistados sobre os possíveis impactos da Hidrovia Tocantins-Araguaia sobre os municípios tocantinenses onde atuam

\begin{tabular}{|c|c|c|c|c|c|c|c|c|}
\hline & \multicolumn{8}{|c|}{ Expectativa de Impacto $(n=24)$} \\
\hline & \multicolumn{3}{|c|}{ Ocorrência } & \multicolumn{2}{|c|}{ Sentido } & \multicolumn{3}{|c|}{$\begin{array}{c}\text { Intensidade (notas } \\
\text { de } 0 \text { a } 10 \text { ) }\end{array}$} \\
\hline & $\operatorname{Sim} 1$ & Não & $\begin{array}{l}\text { Não } \\
\text { Sabe }\end{array}$ & $\begin{array}{c}\text { Aumen- } \\
\text { to }\end{array}$ & $\begin{array}{l}\text { Dimi- } \\
\text { nuição }\end{array}$ & Moda & $\begin{array}{c}\text { Media- } \\
\text { na }\end{array}$ & - Média \\
\hline Agricultura & 22 & 2 & 0 & 22 & 0 & 8 & 7 & 6,0 \\
\hline Indústria e comércio & 22 & 2 & 0 & 22 & 0 & 5 & 6 & 5,8 \\
\hline Turismo & 23 & 1 & 0 & 23 & 0 & 10 & 8 & 7,3 \\
\hline Emprego e renda & 24 & 0 & 0 & 24 & 0 & 8 & 5,5 & 6,0 \\
\hline Valor das propried. ribeirinhas & 23 & 1 & 0 & 22 & 1 & 10 & 5,5 & 5,9 \\
\hline Oportunidades locais & 23 & 1 & 0 & 23 & 0 & 8 & 5 & 5,7 \\
\hline Arrecadação municipal & 24 & 0 & 0 & 24 & 0 & 3 & 4,5 & 5,1 \\
\hline Gastos públicos municipais & 22 & 2 & 0 & 22 & 0 & 3 & 3 & 3,9 \\
\hline Serviços públicos estruturais & 23 & 1 & 0 & 23 & 0 & 6 & 5,5 & 5,3 \\
\hline Serviços públicos sociais & 23 & 1 & 0 & 22 & 1 & 7 & 4 & 4,6 \\
\hline Integração com regiões exteriores & 24 & 0 & 0 & 24 & 0 & 7 & 6 & 6,2 \\
\hline Atividades culturais e de lazer & 23 & 1 & 0 & 23 & 0 & 5 & 5 & 5,0 \\
\hline Variedade da fauna local & 19 & 5 & 0 & 0 & 19 & 0 & 4 & 3,9 \\
\hline Variedade da flora local & 19 & 5 & 0 & 0 & 19 & 0 & 4 & 4,1 \\
\hline Ocorrência de cheias e enchentes & 13 & 10 & 1 & 1 & 12 & 0 & 3,5 & 3,5 \\
\hline Qualidade da água do rio & 19 & 5 & 0 & 1 & 18 & 3 & 3 & 3,2 \\
\hline
\end{tabular}

Fonte: dados da pesquisa 
Tabela 18. Expectativas dos entrevistados sobre os possíveis impactos das Hidrovias Araguaia e Tocantins sobre os municípios tocantinenses onde atuam

\begin{tabular}{|c|c|c|c|c|c|c|c|c|}
\hline \multirow{3}{*}{ Setor do Município } & \multicolumn{8}{|c|}{ Expectativa de Impactos } \\
\hline & \multicolumn{3}{|c|}{ Ocorrência } & \multicolumn{2}{|c|}{ Sentido } & \multicolumn{3}{|c|}{$\begin{array}{l}\text { Intensidade (notas de } 0 \mathrm{a} \\
10 \text { ) }\end{array}$} \\
\hline & Sim & Não & Não Sabe & Aumento & Diminuição & Moda & Mediana & Média \\
\hline \multicolumn{9}{|l|}{ Hidrovia Araguaia $(n=6)$} \\
\hline Agricultura & 6 & 0 & 0 & 6 & 0 & 8 & 7 & 6,2 \\
\hline Indústria e comércio & 5 & 1 & 0 & 5 & 0 & - & 4,5 & 4,5 \\
\hline Turismo & 5 & 1 & 0 & 5 & 0 & 10 & 6,5 & 5,8 \\
\hline Emprego e renda & 6 & 0 & 0 & 6 & 0 & 4 & 5 & 5,7 \\
\hline Valor das propriedades ribeirinhas & 6 & 0 & 0 & 6 & 0 & 4 & 4 & 5,5 \\
\hline Oportunidades locais & 5 & 1 & 0 & 5 & 0 & 5 & 5 & 4,7 \\
\hline Arrecadação municipal & 6 & 0 & 0 & 6 & 0 & 10 & 5,5 & 6,0 \\
\hline Gastos públicos municipais & 6 & 0 & 0 & 6 & 0 & 8 & 5 & 4,8 \\
\hline Serviços públicos estruturais & 6 & 0 & 0 & 6 & 0 & 5 & 5 & 4,7 \\
\hline Serviços públicos sociais & 6 & 0 & 0 & 6 & 0 & - & 5,5 & 5,2 \\
\hline Integração com regiões exteriores & 6 & 0 & 0 & 6 & 0 & 10 & 7 & 7,3 \\
\hline Atividades culturais e espaços lazer & 6 & 0 & 0 & 6 & 0 & - & 6,5 & 6,5 \\
\hline Variedade da fauna local & 1 & 5 & 0 & 0 & 1 & 0 & 0 & 1,7 \\
\hline Variedade da flora local & 1 & 5 & 0 & 0 & 1 & 0 & 0 & 1,7 \\
\hline Ocorrência de cheias e enchentes & 2 & 4 & 0 & 0 & 2 & 0 & 0 & 1,8 \\
\hline Qualidade da água do rio & 2 & 4 & 0 & 0 & 2 & 0 & 0 & 0,8 \\
\hline \multicolumn{9}{|l|}{ Hidrovia Tocantins $(n=18)$} \\
\hline Agricultura & 16 & 2 & 0 & 16 & 0 & 8 & 6,5 & 6,8 \\
\hline Indústria e comércio & 17 & 1 & 0 & 17 & 0 & 5 & 6 & 6,2 \\
\hline Turismo & 18 & 0 & 0 & 18 & 0 & 10 & 8 & 7,7 \\
\hline Emprego e renda & 18 & 0 & 0 & 18 & 0 & 8 & 5,5 & 6,1 \\
\hline Valor das propriedades ribeirinhas & 17 & 1 & 0 & 16 & 1 & 5 & 6 & 6,1 \\
\hline Oportunidades locais & 18 & 0 & 0 & 18 & 0 & 4 & 5,5 & 6,0 \\
\hline Arrecadação municipal & 18 & 0 & 0 & 18 & 0 & 3 & 4,5 & 4,8 \\
\hline Gastos públicos municipais & 16 & 2 & 0 & 16 & 0 & 3 & 3 & 3,6 \\
\hline Serviços públicos estruturais & 18 & 0 & 0 & 18 & 0 & 6 & 6 & 5,5 \\
\hline Serviços públicos sociais & 17 & 1 & 0 & 16 & 1 & 4 & 4 & 4,4 \\
\hline Integração com regiões exteriores & 18 & 0 & 0 & 18 & 0 & 3 & 6 & 5,8 \\
\hline Atividades culturais e espaços lazer & 17 & 1 & 0 & 17 & 0 & 5 & 4,5 & 4,6 \\
\hline Variedade da fauna local & 18 & 0 & 0 & 0 & 18 & 5 & 4,5 & 4,7 \\
\hline Variedade da flora local & 18 & 0 & 0 & 0 & 18 & 4 & 4 & 4,9 \\
\hline Ocorrência de cheias e enchentes & 11 & 6 & 1 & 1 & 10 & 0 & 5 & 4,1 \\
\hline Qualidade da água do rio & 17 & 1 & 0 & 1 & 16 & 3 & 3 & 4,0 \\
\hline
\end{tabular}

Fonte: dados da pesquisa 
Em termos de intensidade dos impactos econômicos e sociais da Hidrovia Tocantins-Araguaia nos municípios, os entrevistados revelam, na escala de zero a 10, médias entre 4 e 7, com modas entre 3 e 10 e medianas de 3 a 8. Dentre as atividades econômicas, o aumento das atividades de turismo concentra a maior expectativa de intensidade média $(7,3)$ seguido pela agricultura (média 6) e indústria e comércio (média 5,8). Associado a isso, a intensidade esperada sobre a geração de emprego, renda e de novas oportunidades locais demonstra médias iguais a 6 e a 5,7, respectivamente. Decorrente disso e da expectativa de valorização das propriedades ribeirinhas (média 5,9) os entrevistados acreditam que a Hidrovia Tocantins-Araguaia promova o aumento da arrecadação municipal com intensidade média igual a 5,1 , refletindo-se no aumento equivalente dos serviços estruturais prestados pelo município. Quanto aos gastos municipais como um todo a impressão dos entrevistados é de aumento menos intenso, com valor médio igual a 3,9. A maior influência da hidrovia com os aspectos sociais dos municípios é esperada na integração de seus municípios com regiões e comunidades exteriores, cuja intensidade média registrada foi igual a 6,2. Sobre os impactos ambientais a expectativa é de que haja perda da diversidade da fauna, da flora e da qualidade da água do rio com intensidades médias variando entre 3,2 e 4,1. A expectativa de diminuição da ocorrência de cheias e enchentes nos municípios apresentou intensidade média igual a 3,5. É importante observar que grande parte dos entrevistados argumentou que a falta de informações mais precisas sobre os impactos ambientais da hidrovia dificultava a estimação da intensidade dos impactos, apesar da convicção em sua ocorrência e sentido. Esse perfil de resultados da amostra como um todo é semelhante aos das Hidrovias Araguaia e Tocantins, quando analisadas individualmente.

Diante dos resultados expressos pelas Tabelas 17 e 18 observa-se que, de modo geral, os entrevistados acreditam que a Hidrovia TocantinsAraguaia promoverá, nos municípios onde atuam, aumentos médios da 
atividade econômica e da ação social, bem como uma perda de baixa intensidade da qualidade ambiental. Essa concepção Ihes permite, assim, estabelecer o grau de importância da implantação e operação da hidrovia para o município, como será tratado a seguir.

\subsubsection{Impressões sobre a importância para o município}

Captadas as expectativas dos entrevistados sobre os impactos individuais da Hidrovia Tocantins-Araguaia em seus municípios, procedeu-se à estimação da importância geral da presença local dessa infra-estrutura, conforme demonstra a Tabela 19. Observa-se que para os lindeiros à Hidrovia Tocantins-Araguaia o grau de importância é elevado, com média 7,7, moda 8 e mediana 8. No caso das Hidrovias Araguaia e Tocantins, particularmente, a manifestação dos entrevistados foi muito próxima. Isso fica corroborado pelos resultados da questão relacionada à realização de investimentos públicos ou de contribuição institucional/empresarial para a implantação dessa hidrovia, também evidenciada na Tabela 19. Verifica-se que a maioria declarou-se favorável a um investimento público médio da ordem de $6,4 \%$ do orçamento municipal e à contribuição institucional ou privada média de $7,2 \%$ do orçamento da instituição ou da renda bruta empresarial anual, o que equivale em média a $\mathrm{R} \$ 67.857,00$ por ano. Destaca-se que, quando os entrevistados declararam-se contrários ao investimento municipal ou institucional na hidrovia, os motivos mais freqüentes foram a existência de outras prioridades institucionais/empresariais ou a baixa capacidade para investimentos das instituições e das empresas locais. Além desses, a manifestação de que a implantação da Hidrovia Tocantins-Araguaia é responsabilidade financeira da União também foi anotada. 
Tabela 19. Considerações dos entrevistados sobre a importância da Hidrovia Tocantins-Araguaia para o município tocantinense onde atuam

\begin{tabular}{|c|c|c|c|c|c|c|c|c|}
\hline \multirow{5}{*}{ Indicador } & \multirow{5}{*}{$\begin{array}{l}\text { Importância } \\
\text { (nota de } 0 \text { a } \\
10)\end{array}$} & \multirow{2}{*}{\multicolumn{3}{|c|}{$\begin{array}{l}\text { Investimento de } \\
\text { recursos municipais na }\end{array}$}} & \multicolumn{4}{|c|}{ Contribuição } \\
\hline & & & & & \multicolumn{4}{|c|}{$\begin{array}{l}\text { institucional/empresarial para } \\
\text { implantação da Hidrovia }\end{array}$} \\
\hline & & \multicolumn{3}{|r|}{$\%$ do } & & & $\%$ do & Valor \\
\hline & & Sim & Não & Orçamento & Sim & Não & Orçamento / & Anual \\
\hline & & & & Municipal & & & Renda Bruta & $(\mathrm{R} \$)$ \\
\hline
\end{tabular}

Hidrovia Araguaia $(n=6)$

$\begin{array}{lcccccccc}\text { N } & - & 5 & 1 & - & 4 & 2 & - & - \\ \text { Moda } & 10 & - & - & - & - & - & - & - \\ \text { Mediana } & 8,5 & - & - & 5 & - & - & 6 & 27500 \\ \text { Média } & 7,5 & - & - & 6,6 & - & - & 6,9 & 28750\end{array}$

Hidrovia Tocantins $(n=18)$

$\begin{array}{lcccccccc}\text { N } & - & 15 & 3 & - & 3 & 15 & - & - \\ \text { Moda } & 7 & - & - & 10 & - & - & 10 & 150000 \\ \text { Mediana } & 7,5 & - & - & 5 & - & - & 10 & 150000 \\ \text { Média } & 7,7 & - & - & 6,3 & - & - & 7,7 & 120000\end{array}$

Hidrovia Tocantins-Araguaia $(n=24)$

\begin{tabular}{lcccccccc} 
N & - & 20 & 4 & - & 7 & 17 & - & - \\
Moda & 8 & - & - & 1 & - & - & 10 & 150000 \\
Mediana & 8 & - & - & 5 & - & - & 10 & 50000 \\
Média & 7,7 & - & - & 6,4 & - & - & 7,2 & 67857 \\
\hline
\end{tabular}

Fonte: dados da pesquisa 


\subsubsection{Inserção nos projetos locais}

Apesar da importância atribuída à Hidrovia Tocantins-Araguaia pelos entrevistados, são poucas as instituições ou empresas que registram projetos econômicos que a envolvam, conforme ilustra a Tabela 20. Pelo que se observa, dentre as 24 representadas apenas 7 declararam ter projetos. Estes, por sua vez, objetivam a construção de estruturas que possibilitem o transporte de insumos e de produtos, a irrigação de áreas agricultáveis às margens dos rios, a integração entre regiões e o turismo ecológico. Neles, a hidrovia é citada como canal de transporte e estrutura de apoio multimodal. Todavia, à exceção da Plataforma Multimodal de Aguiarnópolis cuja implantação está em execução, os demais projetos são, apenas, boas intenções. Deve-se registrar que os entrevistados cujas instituições não têm projetos que incluam a hidrovia alegaram que o ritmo lento na implantação e a inexistência de estrutura operacional disponível causam descrença na sua consolidação. Isso aumenta a importância relativa da malha rodoviária como via de transporte alternativa e prioritária para o município e para suas atividades produtivas. A falta de vontade política para que a hidrovia aconteça também foi assinalada. 
Tabela 20. Projetos públicos ou privados que incorporam a Hidrovia Tocantins-Araguaia declarados pelos entrevistados, segundo 0 município de implantação

\begin{tabular}{|c|c|c|c|c|c|c|c|}
\hline \multirow[b]{2}{*}{ Quest. } & \multirow[b]{2}{*}{ Município } & \multicolumn{3}{|c|}{ Projeto 1} & \multicolumn{3}{|c|}{ Projeto 2} \\
\hline & & Objetivo & $\begin{array}{c}\text { Papel da } \\
\text { HTA }\end{array}$ & Execução & Objetivo & $\begin{array}{c}\text { Papel da } \\
\text { HTA }\end{array}$ & Execução \\
\hline \multicolumn{8}{|c|}{ Hidrovia Araguaia } \\
\hline 2 & Xambioá & $\begin{array}{c}\text { Escoar } \\
\text { calcáreo para o } \\
\text { MT e receber } \\
\text { soja }\end{array}$ & $\begin{array}{l}\text { Canal de } \\
\text { transporte }\end{array}$ & Não & - & - & \\
\hline 5 & $\begin{array}{c}\text { Couto } \\
\text { Magalhães }\end{array}$ & $\begin{array}{c}\text { Estruturar porto } \\
\text { e } \\
\text { equipamentos } \\
\text { para voltar a } \\
\text { operar as } \\
\text { chatas }\end{array}$ & $\begin{array}{l}\text { Canal de } \\
\text { transporte }\end{array}$ & Não & - & - & \\
\hline \multicolumn{8}{|c|}{ Hidrovia Tocantins } \\
\hline 7 & Lajeado & $\begin{array}{l}\text { Aumento do } \\
\text { turismo na } \\
\text { região }\end{array}$ & $\begin{array}{l}\text { Canal de } \\
\text { transporte } \\
\text { de barcos } \\
\text { turísticos }\end{array}$ & Não & $\begin{array}{l}\text { Incrementar } \\
\text { a produção } \\
\text { agrícola } \\
\text { irrigada }\end{array}$ & $\begin{array}{l}\text { Canal de } \\
\text { irrigação }\end{array}$ & Não \\
\hline 10 & Miracema & $\begin{array}{l}\text { Construir orla } \\
\text { turística }\end{array}$ & $\begin{array}{l}\text { Canal de } \\
\text { transporte } \\
\text { de barcos } \\
\text { turísticos }\end{array}$ & Não & - & - & Não \\
\hline 13 & Palmas & $\begin{array}{c}\text { Construir a } \\
\text { Rodovia BR230 } \\
\text { Aguiarnópolis }\end{array}$ & $\begin{array}{l}\text { Apoio à } \\
\text { estrutura de } \\
\text { transporte } \\
\text { multimodal }\end{array}$ & Não & - & - & Não \\
\hline 14 & Palmas & $\begin{array}{l}\text { Construir a } \\
\text { Plataforma } \\
\text { Multimodal de } \\
\text { Aguiarnópolis }\end{array}$ & $\begin{array}{l}\text { Canal de } \\
\text { transporte }\end{array}$ & Sim & $\begin{array}{l}\text { Fortalecer a } \\
\text { Tríplice } \\
\text { Divisa } \\
\text { (PA,MA,TO) }\end{array}$ & $\begin{array}{l}\text { Instrumento } \\
\text { de apoio à } \\
\text { formação de } \\
\text { cluster } \\
\text { industrial na } \\
\text { região }\end{array}$ & Não \\
\hline 17 & Palmas & $\begin{array}{c}\text { Construir a } \\
\text { Plataforma de } \\
\text { abastecimento } \\
\text { de Palmas }\end{array}$ & $\begin{array}{c}\text { Canal de } \\
\text { transporte }\end{array}$ & Não & $\begin{array}{l}\text { Formar o } \\
\text { cinturão } \\
\text { verde de } \\
\text { Palmas } \\
\end{array}$ & $\begin{array}{l}\text { Canal de } \\
\text { irrigação }\end{array}$ & Não \\
\hline
\end{tabular}

Fonte: dados da pesquisa 


\subsubsection{Considerações sobre as informações}

A análise descritiva das informações de campo permite inferir que os entrevistados consideram interessante, oportuna e estratégica a existência e presença da Hidrovia Tocantins-Araguaia. A despeito da pouca informação de que dispõem sobre a dimensão, potencial e impactos dessa infra-estrutura em seus municípios, os entrevistados manifestaram expectativas sobre os diferentes impactos econômicos, sociais e ambientais que ela pode provocar. Muitos assinalaram que o lento processo de implantação compromete a inserção dessa infra-estrutura nos projetos institucionais ou empresariais e causa descrença na sua consolidação. Essa avaliação não difere para o caso das Hidrovias Araguaia e Tocantins quando estudadas separadamente ainda que, no caso da Tocantins, esteja ocorrendo a construção da Plataforma Multimodal de Aguiarnópolis cuja configuração a considera como base. A seguir, os resultados da análise econométrica são apresentados permitindo inferência de outras informações e avaliação das possíveis relações entre a importância da Hidrovia Tocantins-Araguaia para o município e seus impactos locais.

\subsection{Entrevistas individuais: resultados da análise econométrica}

A compreensão dos resultados da análise econométrica deve levar em conta o modelo estatístico testado sobre as impressões dos entrevistados. Esse modelo foi constituído da seguinte forma:

Importância da Hidrovia Tocantins-Araguaia para o município (C1) = função \{

Grau de escolaridade do entrevistado (C2),

Grau de conhecimento e informação sobre a hidrovia (C3), 
Impacto sobre a agricultura do município (C4),

Impacto sobre a indústria e comércio do município (C5),

Impacto sobre o turismo no município (C6),

Impacto sobre a geração de emprego e renda no município (C7),

Impacto sobre o valor das propriedades ribeirinhas no município (C8),

Impacto sobre a oferta de serviços estruturais no município (C9),

Impacto sobre a oferta de serviços sociais no município (C10),

Impacto sobre a diversidade da fauna do município (C11),

Impacto sobre a diversidade da flora do município (12),

Impacto sobre a qualidade da água do rio no município (C13),

Dummy para a ocorrência ou não de impacto (C16)\}

Além disso, foram tomados alguns procedimentos básicos para a realização da análise econométrica, apresentados a seguir.

\subsubsection{Procedimentos básicos}

A análise econométrica do modelo estatístico proposto para os dados sobre a Hidrovia Tocantins-Araguaia, observou alguns procedimentos de modo a estabelecer um grau adequado de confiança para os resultados. A análise dos dados foi realizada utilizando o pacote computacional MINITAB Versão 14 (demo). Em primeiro lugar, considerando que o método de regressão stepwise utilizado baseia-se no teste $F$, tomou-se como nível de confiança para a análise o valor de $\alpha$ igual a 20\%. A escolha desse valor, relativamente alto, é justificada pela natureza subjetiva dos dados relacionados à importância e aos possíveis 
impactos econômicos, sociais e ambientais da Hidrovia Tocantins-Araguaia, quando estimados segundo a visão dos diferentes agentes econômicos entrevistados. A estimação desses indicadores pelos entrevistados fica ainda mais incerta quando se observa que a hidrovia não existe fisicamente, o que os leva a especular sobre efeitos de algo distante de sua realidade atual. Além disso, considera-se, também, o argumento de Pereira (2001) que assinala a dificuldade na mensuração de impactos qualitativos, classificando-a como uma tarefa complexa e desafiadora devido à dificuldade de concepção de variáveis para essa medida na representação do fenômeno estudado, ciente de que o universo dos impactos pode não estar sendo e perfeitamente coberto. Diante disso, completa o autor, uma vez que não há "nota de corte" ideal para a concepção de qualquer indicador, o importante é ter uma avaliação de quão bom ele é por meio do valor de $\alpha$, considerando-se o intervalo de valores possíveis (0-1) e a complexidade do fenômeno que se busca medir.

Considerando que o método de regressão stepwise utiliza as distribuições de $\mathrm{t}$ e de $\mathrm{F}$ para testar as hipóteses a respeito dos valores dos parâmetros ou para constituir os intervalos de confiança e que essas distribuições pressupõem que os erros tenham distribuição aproximadamente normal realizou-se o teste de normalidade para todas as variáveis. Ainda que o reduzido número de observações sob análise tenha sido um fator restritivo, ao nível de confiança estabelecido, as variáveis demonstraram comportamento aproximadamente normal.

Outro procedimento adotado com a finalidade de dar sustentação à análise dos dados sobre a Hidrovia Tocantins-Araguaia foi a identificação de observações que pudessem ser excessivamente discrepantes em relação ao conjunto, utilizando, para isso, uma análise de regressão linear múltipla dos dados. Feito isso, os resultados evidenciaram que as observações de um entrevistado se enquadravam nessa situação. Esse entrevistado, do município de Araguanã, atribuiu, de maneira geral, baixa importância à hidrovia, aos 
possíveis serviços que ela poderia prestar e aos diferentes impactos que poderia causar ao município, sob a alegação de que a prioridade municipal era a malha rodoviária, a despeito de ser uma localidade às margens do rio Araguaia. Essa distinção em relação ao conjunto de observações indicou a necessidade de avaliar os dados com e sem as observações desse entrevistado.

Considerando que as informações sobre os impactos causados pela Hidrovia Tocantins-Araguaia foram captados em três dimensões (ocorrência, sentido e intensidade), procurou-se incorporá-las no modelo de modo a captar o maior efeito possível, segundo a opinião dos entrevistados. Para isso, foi introduzida uma variável dummy para a ocorrência, sendo que foi diferenciada a situação em que o entrevistado identificou a ocorrência de impactos em todos os indicadores assinalados, daquela em que ele afirmou não haver impacto em pelo menos um deles. A dimensão sentido, por sua vez, foi incorporada à intensidade através da ampliação da escala de intensidade para valores entre 10 e 10, ou seja, quando o sentido da ocorrência foi a diminuição, o valor anotado recebeu o sinal negativo e, quando foi o aumento, o sinal recebido foi positivo. Esse procedimento pode ser justificado pelo fato de que o entrevistado, quando perguntado sobre o sentido do impacto, assinalou a dimensão a partir da situação atual, tomada por referência ou estado neutro (ou valor zero), o que permite considerar uma variação positiva ou negativa para a intensidade, levando em consideração o sentido da ocorrência.

\subsubsection{Caracterização dos dados}

$\mathrm{Na}$ intenção de reforçar os preparativos para a regressão stepwise sobre os dados procurou-se observar, também, o perfil de cada variável, ilustrado na Figura 12 que, através de um gráfico tipo boxplot, revela, para cada 
variável utilizada na análise, a dispersão dos dados e o posicionamento do $1^{\circ} \mathrm{e}$ $3^{0}$ quartis, da mediana e da média dos dados.

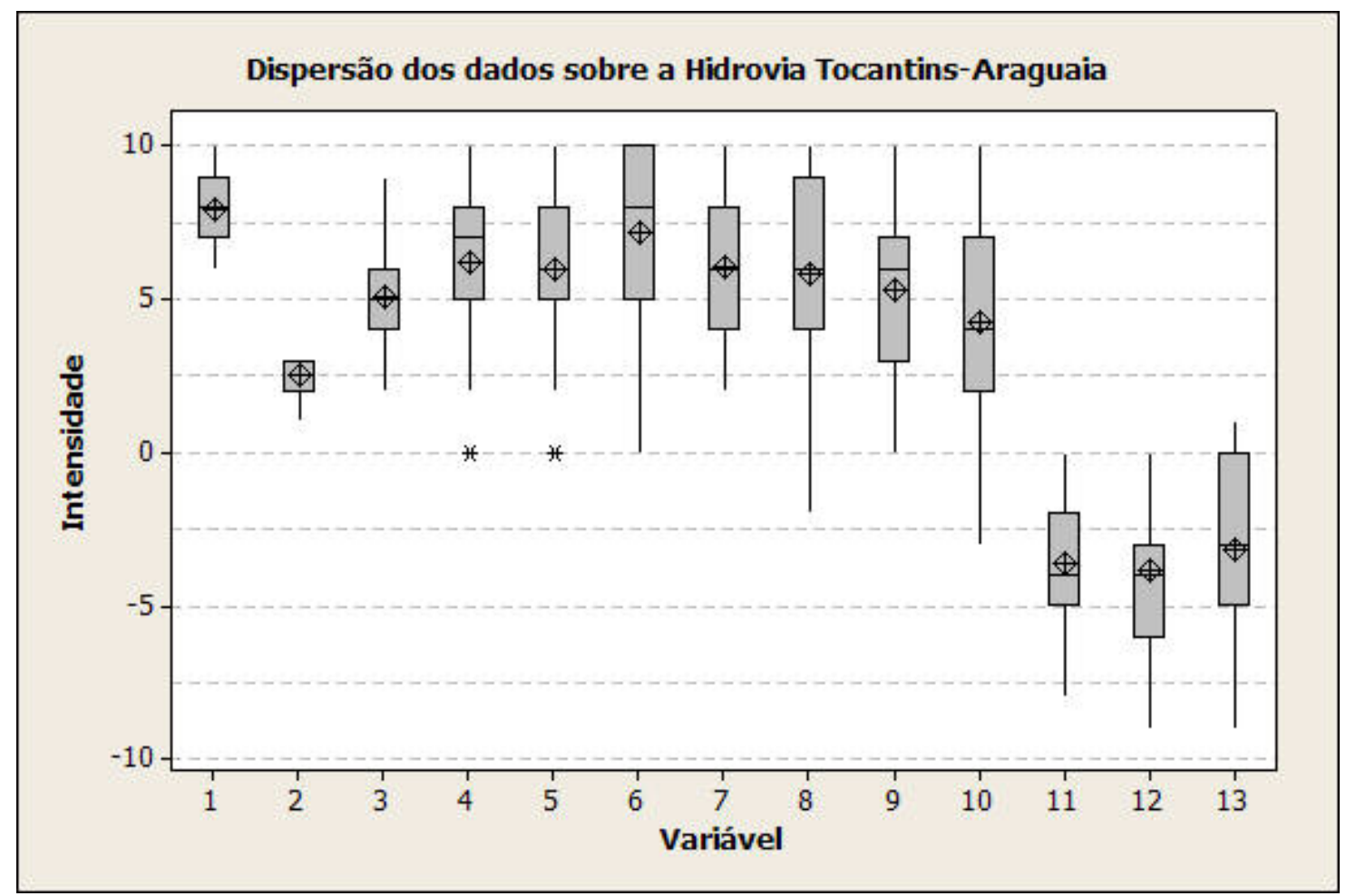

Figura 12 - Perfil de distribuição dos dados levantados sobre a Hidrovia Tocantins-Araguaia, segundo a variável selecionada

Fonte: dados da pesquisa

A Figura 12, primeiramente, revela a distinção entre um grupo de varáveis com valores predominantemente positivos e, outro, com valores negativos. As variáveis do primeiro grupo dizem respeito à importância da Hidrovia Tocantins-Araguaia para o município (C1), ao grau de escolaridade (C2) e de conhecimento e informação sobre a hidrovia (C3) do entrevistado e aos impactos econômicos e sociais dessa infra-estrutura (C4 a C10). No 
segundo grupo estão as variáveis referentes aos impactos ambientais (C11 a C13).

Em relação à amplitude dos dados, percebe-se que as variáveis $\mathrm{C} 1 \mathrm{e}$ C2 têm pequena dispersão, quando comparadas às demais. Por outro lado, as variáveis C6 (impacto sobre o turismo) C8 (impacto sobre o valor das propriedades ribeirinhas), C9 (impacto sobre os serviços estruturais municipais), C10 (impacto sobre os serviços sociais municipais) e C13 (impacto sobre a qualidade da água) são as que apresentam a maior dispersão, inclusive com C8 e C10 contendo valores positivos e negativos, o que indica expectativas de aumento e de diminuição na ocorrência dos impactos.

Outro aspecto que chama a atenção na Figura 12 é a posição do $1^{\circ} \mathrm{e}$ do $3^{\circ}$ quartís, cujo intervalo reflete a localização de $50 \%$ dos dados e que aparecem localizados centralmente na distribuição dos dados da maioria das variáveis. A exceção fica por conta das variáveis C6 (impacto no turismo), C8 (impacto nos serviços estruturais) e C13 (impacto na qualidade da água) cujos quartís estão deslocados no sentido dos maiores valores de intensidade dos impactos.

Quanto à mediana e à média, observa-se que coincidem, ou estão muito próximas, na maioria das variáveis, o que poderia reforçar a hipótese de que tenham distribuição aproximadamente normal. Um afastamento significativo entre ambas é visualizado apenas nas variáveis C4 (impacto sobre a agricultura), C6 (impacto no turismo) e C9 (impacto sobre os serviços sociais), onde a média é menor do que a mediana, o que caracterizaria, segundo Hoffman (1980), uma distribuição negativamente assimétrica. Vale ressaltar que as variáveis C4 (impacto sobre a agricultura) e C5 (impacto sobre a indústria e comércio) apresentam duas observações muito discrepantes das demais, assinaladas com um asterisco. 


\subsubsection{Resultados da regressão stepwise}

Tendo sido tomados os procedimentos necessários quanto ao estabelecimento do valor de $\alpha$, ao teste de normalidade das variáveis, à identificação das observações discrepantes da amostra e à introdução da variável dummy, submeteram-se os dados à regressão stepwise, primeiramente com todas as observações e, em seguida, sem as observações discrepantes referentes ao questionário de Araguanã, para verificar a sua interferência. Esse procedimento revelou que o ajustamento do modelo melhorou, substancialmente, em termos do número de variáveis estabilizadas no modelo e do coeficiente de determinação $R^{2}$, quando tais observações foram desconsideradas da amostra. Feito isso, o modelo selecionado pelo método stepwise foi o seguinte:

$\mathbf{C} 1=8,932+0,200 \mathbf{C} \mathbf{7}-1,170 \mathbf{C} 2+0,393 \mathbf{C} \mathbf{-}-0,115 \mathbf{C} \mathbf{6}-0,118 \mathbf{C 1 0}+0,106 \mathbf{C} \mathbf{8}-0,111 \mathbf{C} \mathbf{5}$

em que:

C1 = Importância da Hidrovia Tocantins-Araguaia;

C7 = Geração de emprego e renda;

C2 = Conhecimento e informação sobre a HTA;

$\mathbf{C 9}=$ Oferta de serviços estruturais municipais;

$\mathbf{C 6}=$ Atividades de turismo;

C10 = Oferta de serviços sociais municipais;

$\mathbf{C 8}=$ Valor das propriedades ribeirinhas;

C5 = Atividades de indústria e comércio;

Esse modelo mostrou um coeficiente de determinação $\mathrm{R}^{2}$ igual a 85,46\% e um $\mathrm{R}^{2}$ ajustado para os graus de liberdade igual a $78,67 \%$. Os resultados individuais sobre as variáveis e para o modelo estão apresentados no Quadro 5. 


\begin{tabular}{|l|r|r|r|}
\hline \multicolumn{1}{|c|}{ Variável Independente } & Coeficiente & \multicolumn{1}{c|}{ Valor t } & Valor $\mathrm{p}$ \\
\hline Impactos sobre & & & \\
\hline C7 = Geração de emprego e renda & 0,200 & 1,78 & 0,096 \\
\hline C2 = Conhecimento e informação sobre HTA & $-1,170$ & $-4,44$ & 0,000 \\
\hline C9 = Oferta de serviços estruturais municipais & 0,393 & 4,21 & 0,001 \\
\hline C6 = Atividades de turismo & $-0,115$ & $-1,78$ & 0,095 \\
\hline C10 = Oferta de serviços sociais municipais & $-0,118$ & $-2,14$ & 0,049 \\
\hline C8 = Valor das propriedades ribeirinhas & 0,106 & 1,60 & 0,130 \\
\hline C5 = Atividades de indústria e comércio & $-0,111$ & $-1,38$ & 0,189 \\
\hline \multicolumn{2}{|c|}{ Resultados Globais: } \\
\hline Número de passos & 7 \\
\hline $\mathrm{R}^{2}$ & 78,46 \\
\hline $\mathrm{R}^{2}$ ajustado & \multicolumn{3}{|c|}{} \\
\hline
\end{tabular}

Quadro 5 - Resultados da análise econométrica do modelo estatístico sobre a Hidrovia Tocantins-Araguaia, segundo as variáveis selecionadas pelo método de regressão linear stepwise

Fonte: dados da pesquisa

A observação do Quadro 5 permite verificar que os resultados individuais são significativos, segundo o valor de $p$, para as variáveis selecionadas pelo modelo, sob $\alpha=0,20$ estabelecido à priori. Em termos de sinais da relação entre cada variável independente e a dependente, no caso a importância da Hidrovia Tocantins-Araguaia para o município, nota-se que são positivos os coeficientes da Geração de emprego e renda, Oferta de serviços estruturais municipais e Valor das propriedades ribeirinhas, indicando que, segundo as impressões dos entrevistados, a importância da hidrovia estaria relacionada à sua capacidade de promover um aumento nesses indicadores. Esses resultados corroboram as expectativas declaradas no modelo estatístico proposto.

Quanto aos sinais negativos dos coeficientes das variáveis Conhecimento e informação sobre a HTA, Atividades de turismo, Oferta de serviços sociais municipais e Atividades de indústria e comércio cabe uma 
avaliação separada da relação com a variável Conhecimento e informação sobre a Hidrovia Tocantins-Araguaia. Sobre ela não foi estabelecido, previamente, um sinal. A obtenção do negativo pode ser entendida pelo fato de que à medida que aumenta o grau de conhecimento e informação sobre a importância dessa infra-estrutura e, também, sobre o grau de desarticulação do seu processo de implantação, os agentes econômicos desacreditam de sua consolidação e, por isso, Ihe atribuem importância menor. Para os coeficientes das demais variáveis, esperava-se um sinal positivo, imaginando a associação positiva entre a importância e os impactos causados em cada uma delas. Contudo, os resultados evidenciam que, apesar da expectativa de melhora qualitativa nesses indicadores, os valores declarados pelos entrevistados mostram, na realidade, uma relação inversa entre a intensidade da variação causada nos indicadores e a importância atribuída à hidrovia. Uma explicação para isso seria a incerteza dos entrevistados quanto aos efeitos diretos dessa infra-estrutura sobre as atividades de turismo e de indústria e comércio, bem como sobre a oferta de serviços sociais no município. Isso também pode explicar o fato da variável que trata da relação com as atividades de agricultura não ter, sequer, permanecido no modelo ajustado. Quanto à dummy sobre a ocorrência do impacto, introduzida no modelo, não se observou nenhuma colaboração significativa.

\subsubsection{Considerações sobre os resultados econométricos}

À luz dos resultados obtidos na regressão stepwise, observa-se que os agentes econômicos relacionam a importância da Hidrovia TocantinsAraguaia para seus municípios aos impactos econômicos, sociais e ambientais que ela possa causar em suas localidades. Ainda que nem todas as variáveis relativas aos impactos tenham sido selecionadas pela regressão, as que o foram estão dentro do nível de confiança que se julgou razoável para o modelo 
proposto. Esses resultados reforçam a hipótese principal deste estudo que assinala que os agentes econômicos dos principais municípios tocantinenses lindeiros aos rios Araguaia e Tocantins consideram importante a presença da hidrovia em seus municípios, como infra-estrutura prestadora de serviços de transporte, e têm expectativas sobre a ocorrência, o sentido e a intensidade dos impactos econômicos, sociais e ambientais causados por ela, a despeito de sua atual inexistência física e operacional, o que os leva a não considerá-la em seus projetos institucionais. Isso é um forte indicativo de que os idealizadores dos projetos de infra-estrutura de transporte devem considerar essas expectativas quando da avaliação e seleção dos projetos, com vistas a garantir a escolha de um projeto que seja também interessante aos potenciais usuários e/ou beneficiários, segundo o seu ponto de vista.

\subsection{Grupo focal: aspectos da participação}

O grupo focal sobre a Hidrovia Tocantins-Araguaia foi realizado contando com a participação de alguns dos agentes econômicos entrevistados individualmente e, também, de outros que somente nesta etapa puderam colaborar com a pesquisa, mas que detinham alguma informação ou conhecimento sobre o assunto. É importante ressaltar que essa condição de conhecimento não foi eliminatória para o convite, mas foi orientadora da escolha dos convidados. Tal cuidado se deveu ao fato de que, como se observou no trabalho individual, atualmente poucos indivíduos têm maior percepção sobre a Hidrovia e, por isso, disposição e condição de discutí-la. Diante disso, algumas pessoas, especialmente do setor privado, foram convidadas para a reunião, por entender que seus negócios poderiam, de algum modo, ser influenciados pela presença da Hidrovia.

A reunião foi agendada para acontecer no espaço empresarial do Instituto Euvaldo Lodi (IEL), do Sistema da Federação das Indústrias do Estado 
do Tocantins (FIETO), em Palmas, tentando constituir um ambiente que propiciasse a discussão e a emissão de opiniões sobre aquela infra-estrutura de transporte. Ainda assim, os empresários esquivaram-se do convite alegando que suas atividades estavam relacionadas ao transporte rodoviário e que detinham pouca ou nenhuma informação sobre a Hidrovia. Entre os técnicos do setor público a alegação do pouco conhecimento também foi utilizada como motivo para o não comparecimento. Além disso, vale ressaltar que alguns declararam-se pouco confortáveis com o fato da conversa ser gravada, sugerindo que esse procedimento não era favorável do ponto de vista político. Após duas tentativas infrutíferas, finalmente um grupo se consolidou e permitiu a realização da reunião. Dentre os participantes estiveram técnicos de diferentes estruturas do setor público e um representante da iniciativa privada que solicitou posicionar-se apenas como observador da discussão. Assim, estiveram presentes: Lúcia Leiko, Coordenadora do Meio Ambiente do Departamento de Estradas e Rodagem do Estado do Tocantins (DERTINS); Joaquim Cifuentes, Diretor de Pesquisa da Secretaria de Estado do Planejamento e do Meio Ambiente do Estado do Tocantins (SEPLAM); Waldecy Rodrigues, Professor Adjunto do Curso de Ciências Econômicas da Fundação Universidade Federal do Tocantins (UFT); João Aparecido da Cruz, Diretor de Indústria e Comércio da Secretaria de Estado da Indústria, Comércio e Turismo do Estado do Tocantins (SICTUR); e, José Roberto Fernandes, Diretor Executivo do Sistema de Inteligência da Federação das Indústrias do Estado do Tocantins (FIETO).

\subsubsection{Considerações do grupo sobre a HTA}

Estimulado, inicialmente, a discutir o transporte no Tocantins, o grupo ressaltou a posição estratégica que o Estado ocupa em relação à região e ao País. Segundo a opinião comum, essa característica confere ao Tocantins uma 
posição favorável, mas também de elevada responsabilidade no que respeita à consolidação e modernização de sua infra-estrutura de transporte, seja para atender aos estados vizinhos, seja para reduzir seus custos internos de produção e elevar sua competitividade. Foi assinalado que a ampliação da malha viária pode permitir a expansão da fronteira agrícola e das atividades industriais locais, observando-se que a matriz viária planejada está baseada na matriz produtiva que se pretende atender, respeitando-se os aspectos ambientais e a questão indígena que é marcante no Estado.

Na seqüência, os participantes foram convidados a discutir a Hidrovia Tocantins-Araguaia, quanto aos aspectos econômicos, sociais e ambientais. A opinião comum foi de que essa infra-estrutura é fundamental à expansão das atividades econômicas do Estado, principalmente no que se refere à produção de soja e de outras commodities que se favorece quando há escala no transporte. A importância foi ressaltada tanto no escoamento de produtos para o mercado internacional, através da saída norte do País, quanto na aquisição de insumos destinados à produção agropecuária e industrial na região composta pelo Tocantins e circunvizinhos. Sua existência pode funcionar como um indutor de competitividade.

A discussão sobre a Hidrovia Tocantins-Araguaia trouxe à tona o aspecto ambiental. Os participantes assinalaram que essa infra-estrutura trás um risco ambiental elevado, principalmente para o Rio Araguaia, cujo leito ainda está em formação, sendo raso e indefinido. A preocupação com os impactos diretos ao rio e às espécies que o utilizam como berçário ficou evidente. Agravante é o fato desses impactos serem de difícil mensuração, como foi assinalado pelo grupo. Quanto ao Rio Tocantins, a preocupação ainda que exista tem menor dimensão, uma vez que se trata de um rio com calha profunda e definida, o que parece favorecer a implantação da hidrovia com menor impacto ambiental. Mesmo assim, segundo o grupo é preciso atenção ao processo. No aspecto ambiental foi levantado que, mesmo sob alto risco, a 
implantação de projetos de grandes dimensões como o da Hidrovia TocantinsAraguaia propiciam também ações ambientais e sociais que não aconteceriam ou aconteceriam lentamente, na ausência desses projetos.

Ao final da reunião, foram assinalados os setores que seriam beneficiados pela Hidrovia Tocantins-Araguaia. O consenso foi o setor primário, principalmente relacionado à produção de commodities, especialmente a soja. Esse benefício estaria tanto na exportação do grão, quanto no acesso de menor custo aos insumos importados. Vale lembrar que a carga de retorno estimula os setores comercial e produtivo internos e fortalece a cadeia produtiva. A esse aumento da atividade econômica estaria associado o aumento do emprego e da renda regionais, bem como alguns ganhos de natureza social para as populações lindeiras, favorecendo a formação de pólos regionais relevantes.

Uma discordância no grupo foi quanto ao impacto que a Hidrovia teria sobre o turismo no Estado. Parte dos presentes assinalou que o turismo se beneficiaria pelo fato de que essa infra-estrutura possibilitaria o acesso a regiões ribeirinhas inéditas. Outra parte observou que o turismo na região deve receber impacto negativo devido à perda do atrativo natural provocado pela modificação das características naturais dos rios, bem como pela intensa movimentação dos comboios. O Rio Araguaia deve ser um dos mais prejudicados.

De modo geral, as opiniões emitidas pelo grupo levam à conclusão que, a despeito dos possíveis impactos negativos, principalmente sobre o meio ambiente, a Hidrovia Tocantins-Araguaia trará benefícios econômicos e sociais relevantes ao Estado do Tocantins e aos seus circunvizinhos.

Tomando por base os argumentos teóricos e as evidências de campo reunidos até aqui, assinalam-se, no Capítulo 7, a seguir, as conclusões e algumas sugestões do estudo. 


\section{CONCLUSÕES E SUGESTÕES}

Definida em função dos serviços que presta à sociedade, a infraestrutura de transporte facilita a realização das atividades produtivas e sociais de indivíduos e empresas. Ao propiciar condições para o crescimento econômico, torna-se essencial ao desenvolvimento, ainda que não seja suficiente para o induzir. Diante disso, considera-se fundamental a avaliação ampla dos impactos desse tipo de projeto, buscando melhores condições para sua ordenação e escolha pelos tomadores de decisão. Dada a limitação dos recursos financeiros públicos e privados para investimento em infra-estrutura, uma análise global que inclua aspectos qualitativos e quantitativos, amplia o alcance da tradicional análise benefício-custo e expressa melhor a qualidade dos projetos.

Uma vez que um projeto de infra-estrutura de transporte pode atender um grande contingente de potenciais usuários, é necessário que sejam conhecidas suas expectativas sobre os possíveis impactos que a infra-estrutura possa causar em seus negócios e vidas. Esse contraponto é fundamental para o melhor dimensionamento da importância do projeto, uma vez que pode servir de parâmetro de ponderação para as visões do projetista e do empreendedor. Cabe a ambos conhecer e administrar tais expectativas, no sentido de promover maior interação dessa infra-estrutura com os projetos institucionais públicos e privados, garantindo ao empreendimento retornos econômico e social adequados. É fato que essas expectativas não são facilmente mensuráveis; porém, isso não justifica que sejam desprezadas. Melhor, é 
aperfeiçoar sua mensuração e incorporá-las nos métodos tradicionais de análise.

A conclusão pela necessidade de se ampliar a análise dos projetos de infra-estrutura de transporte motivou este estudo sobre a Hidrovia TocantinsAraguaia. Ao analisar as impressões individuais dos agentes econômicos tocantinenses sobre ela depreende-se que consideram sua presença oportuna e estratégica tanto para seus municípios, quanto para o Estado. Porém, o lento processo de implantação e a aparente falta de vontade política nesse sentido comprometem sua inserção mais efetiva nos projetos institucionais ou empresariais e causa descrença sobre sua consolidação. A análise estatística dos resultados mostrou que os agentes econômicos locais têm impressões significativas a respeito da importância e impactos da hidrovia nos municípios, a despeito da sua atual inexistência física. Isso é um forte indicativo de que essas impressões também deveriam ser consideradas pelo empreendedor do projeto, de modo a torná-lo mais interessante aos usuários. A análise feita através de um grupo focal permite concluir pela sua particular importância na expansão da atividade econômica do Estado, especialmente no escoamento de produtos agrícolas para o mercado internacional, através da saída norte do País e na aquisição de insumos agropecuários e industriais. A esse aumento da atividade econômica estariam associados, também, o crescimento do emprego e da renda regionais e alguns ganhos sociais para as populações lindeiras, o que favoreceria a formação de pólos regionais. Por outro lado, a perda da qualidade ambiental nos locais onde essa infra-estrutura pode alcançar, revelou-se preocupação comum e marcante. Apesar disso, conclui-se que a expectativa geral é de que a Tocantins-Araguaia traga mais benefícios do que custos ao Estado do Tocantins e aos seus circunvizinhos.

A preocupação com o impacto ambiental na implantação e operação da Hidrovia Tocantins-Araguaia, no Estado do Tocantins está relacionada, 
especialmente, ao Rio Araguaia cuja juventude e fragilidade dos ecossistemas que congrega, pode ser severamente afetado. Diante disso, recomenda-se um tratamento cuidadoso, baseado num planejamento de intervenções refinado, que respeite suas características naturais, bem como as das espécies e populações que o habitam, inclusive a humana. O Rio Tocantins, ainda que menos indefeso pela sua maior idade, precisa, igualmente, de tratamento adequado, uma vez que dele depende não só a Hidrovia Tocantins e o projeto multimodal de transporte mas, também, todo o projeto de geração de energia hidrelétrica do Estado.

A respeito do ritmo de implantação da Hidrovia Tocantins-Araguaia, vale observar que se medidas efetivas não forem adotadas, a consolidação do sistema de navegação interior, como pretende o Governo Federal, será prejudicada. Na medida em que essa hidrovia serve de elo de ligação entre as do Sul, do Norte e do Nordeste do País, é preciso concentrar esforços institucionais na resolução dos aspectos técnicos e políticos que estejam retardando sua efetivação. A falta de integração na navegação interior aumenta a pressão sobre a infra-estrutura de transporte disponível, principalmente sobre a do modal rodoviário, diminui a eficiência e eleva o custo do transporte de produtos e insumos. Diante disso, pode ficar comprometido o crescimento econômico que o atual governo tanto espera.

A condução desta pesquisa procurou evidenciar a importância dos aspectos qualitativos relacionados aos projetos de infra-estrutura de transporte, especialmente da Hidrovia Tocantins-Araguaia, sob o ponto de vista dos usuários/beneficiários potenciais. De certa forma, buscou-se identificar e, na medida do possível, dimensionar a intensidade dos impactos nesses aspectos, combinando técnicas de entrevista estruturada e de grupo focal. Um método e um modelo estatístico correspondente foram propostos e testados de modo a buscar uma visão mais consubstanciada das expectativas dos agentes econômicos. Porém, esforços ainda precisam ser feitos para que os resultados 
possam ser incorporados às análises de viabilidade econômica dos projetos de infra-estrutura de transporte ou, de outros que tenham equivalente amplitude de impactos. Como sugestão, precisa-se compatibilizar a questão temporal dos aspectos qualitativos e quantitativos. O grande desafio que se estabelece é conseguir a adequada distribuição dos qualitativos ao longo do tempo, de modo que sirvam de parâmetro de ponderação dos quantitativos, cuja projeção no horizonte temporal constitui tarefa mais fácil. Outro trabalho que merece energia é a própria mensuração das questões qualitativas, principalmente daquelas relacionadas ao meio ambiente. As teorias e técnicas de valoração de perdas e ganhos ambientais precisam ser incorporadas aos métodos de avaliação dos projetos, para que os resultados das análises estejam mais próximos da realidade e possam evidenciar pontos positivos e negativos dos empreendimentos, permitindo que a sociedade faça uma escolha mais acertada em termos econômicos, sociais e ambientais. 


\section{REFERÊNCIAS BIBLIOGRÁFICAS}

ABBAD, G.; TORRES, C.V. Regressão múltipla stepwise e hierárquica em Psicologia Organizacional: aplicações, problemas e soluções Estudos de Psicologia, v.7, p.19-29, 2002. Número especial.

ADLER, H.A. Avaliação econômica de projetos de transportes: metodologia e exemplos. Rio de Janeiro: Livros Técnicos e Científicos, 1978. 171p.

ADMINISTRAÇÃO DAS HIDROVIAS DO TOCANTINS E ARAGUAIA (AHITAR). Relatório de impacto sobre o meio ambiente na implantação da hidrovia Tocantins-Araguaia. Belém: Companhia Docas do Pará/AHITAR, 1999. http://www.ahitar.com.br/rima/rima.php (18 jun. 2003)

AHMED, R.; DONOVAN, C. Issues of infrastructural development: a synthesis of the literature. Washington: International Food Policy Research Institute, 1992. 40p.

BARBOUR, R.S.; KITZINGER, J. (Org.). Developing focus group research: policy, theory and practice. London: Sage Publications, 1999. p.1-20: Introduction: the challenge and promise of focus groups.

BARKIN, D. Macro changes and micro analysis: methodological issues in ecological economics. Ecological Economics, v.19, n.3, p.197-200, 1996. 
BERNARDES, E.M. Desenvolvimento do Vale do Tietê-Paraná: um enfoque de estoques de capitais. Piracicaba, 2002. 140p. Tese (Doutorado) - Escola Superior de Agricultura "Luiz de Queiroz", Universidade de São Paulo.

BOUGHEAS, S.; DEMETRIADES, P.O.; MORGENROTH, E.L.W. Infrastructure, transport costs and trade. Journal of International Economics, v.47, n.1, p.169-189, Feb. 1999.

BRASIL. Ministério do Meio Ambiente. Panorama dos recursos hídricos por região hidrográfica. Brasília: Agência Nacional de Águas (ANA), 2003a. http://www.ana.gov.br (28 mar. 2003)

BRASIL. Ministério dos Transportes. Corredores estratégicos de desenvolvimento. Brasília: Empresa Brasileira de Planejamento de Transportes (GEIPOT), 2003c. http://www.transportes.gov.br/ bit/inestudos.htm (16 abr. 2003)

BRASIL. Ministério dos Transportes. Relatório de estatística hidroviária: bacia do tocantins e araguaia. Brasília: Departamento de Hidrovias Interiores, 2003b. http://www.transportes.gov.br (28 mar. 2003)

BRASIL. Ministério dos Transportes. Transporte multimodal de cargas. Brasília: Agência Nacional de Transportes Terrestres (ANTT), 2003d. http://www.antt.gov.br/carga/multimodal/otm.htm (16 abr. 2003)

BRUINSMA, F.; RIETVELD, P. Infrastructure construction and entrepreneurial behaviour. Amsterdam: Vrije Universiteit, 1997. 24p. (Research Memorandum, 34)

BUCHER, E.H.; HUSZAR, P.C. Critical environmental costs of the ParaguayParaná waterway project in South America. Ecological Economics, v.15, n.1, p.3-9, 1995. 
BUCHER, E.H.; HUSZAR, P.C. Project evaluation and economic development: on using benefit-cost analysis to evaluate Hidrovia. Ecological Economics, v.19, n.3, p.201-203, 1996.

CAIXETA-FILHO, J.V.; MARTINS, R.S. (Org.). Gestão logística do transporte de cargas. São Paulo: Atlas, 2001. p.13-31: Evolução histórica da gestão logística do transporte de cargas.

CASTRO, N. Comércio interno e custos de transportes. In: CAIXETA-FILHO, J.V.; MARTINS, R.S. (Org.). Gestão logística do transporte de cargas. São Paulo: Atlas, 2001. p.60-87.

CONFEDERAÇÃO NACIONAL DO TRANSPORTE (CNT). Pesquisa aquaviários CNT - 2002: relatório analítico. Brasília: CNT, 2002b. 49p. http://www.cnt.org.br/download/pesquisas/aquaviaria.pdf (15 mar. 2003)

CONFEDERAÇÃO NACIONAL DO TRANSPORTE (CNT). Transporte de cargas no Brasil: ameaças e oportunidades para o desenvolvimento do País. Brasília: COPPEAD, 2002a. 200p. http://www.cnt.org.br/download/ pesquisas/cnt-coppead-cargas.pdf (15 mar. 2003)

CONSELHO NACIONAL DO MEIO AMBIENTE (CONAMA). Resolução nº 001 de 23 de janeiro de 1986. Diário Oficial da União, 17 fev. 1986. http://www.mma.gov.br/conama/ (06 mar. 2003)

DAILAMI, M.; KLEIN, M. Government support to private infrastructure projects in emerging markets. Washington: World Bank, Country Economics Department, $1997 . \quad$ (RePEc:fth:wobaco:1868) http://netec.mcc.ac.uk/BibEc/data/Papers/fthwobaco1868.html (22 Mar. 2002) 
EBERTS, R. Understanding the impact of transportation on economic development. 2000. http://www.nationalacademies.org/trb/publications/ millennium/00138.pdf (12 Feb. 2003)

ESTACHE, A.; RUS, G. (Ed.). Privatization and regulation of transport infrasctructure. Washington: The World Bank, 2000. p.5-50: The regulations of transport infrastructure and services: a conceptual overview.

FOSTER, D.P.; STINE, R.A. Honest confidence intervals for the error variance in stepwise regression. Filadélfia: The Warthon School of the University of Pennsyvania, 1998. http://www.stat.wharthon.upenn.edu/ bob/ research/ honests2.pdf (03 May 2004)

FRANKLAND, J.; BLOOR, M. Some issues arising in the systematic analysis of focus group materials. In: BARBOUR, R.S.; KITZINGER, J. (Org.). Developing focus group research: policy, theory and practice. London: Sage Publications, 1999. p.144-155.

FUNDAÇÃO CENTRO BRASILEIRO DE REFERÊNCIA E APOIO CULTURAL (CEBRAC). Analysis of the environmental impact study (EIA/RIMA) for the Araguaia-Tocantins hidrovia project: a report by a blue ribbon panel of independent experts. Brasília: CEBRAC, 2000. http://www.environmentaldefense.org/documents/2436_TocantinsSummary. pdf (06 Mar. 2003)

GANNON, C.; LIU, Z. Poverty and transport. 2002. http://www.worldbank.org/ html/fpd/transport/publicat/twu-30.pdf (16 Aug. 2002)

GOMES, M.E.S.; BARBOSA, E.F. A técnica de grupos focais para obtenção de dados qualitativos. Belo Horizonte: Educativa - Instituto de Pesquisa e Inovações Educacionais, 1999. http://www.dppq.cefetmq.br/mtp/ tecnicadegruposfocais.doc (29 abr. 2004) 
GWILLIAM, K.M. La economia del transporte y el desarrolo. In: RUS, G.; NASH, C. Desarrolos recientes en economia del transporte. Madri: Editorial Civitas, 1998. p.393-472.

HENDERSON, J.V.; SHALIZI, Z.; VENABLES, A.J. Geography and development. Journal of Economic Geography, v.1 n.1, p.81-105, 2001. http://netec.mcc.ac.uk/BibEc/data/Articles/oupjecgeov:1:y:2001:i:1:p:81105.html. (25 Mar. 2002)

HOFFMANN, R. Estatística para economistas. São Paulo: Pioneira, 1980. $379 p$.

INSTITUTO BRASILEIRO DE GEOGRAFIA E ESTATÍSTICA (IBGE). Estatísticas municipais. Brasília, 2003. http://www.ibge.gov.br/ cidadesat/default.php (01 jul. 2003)

JAPAN INTERNATIONAL COOPERATION AGENCY. Plano diretor de desenvolvimento integrado da agricultura e pecuária do Estado do Tocantins. Palmas: Secretaria do Estado da Agricultura, 1998. 218p.

LAKSMANAN, T.R.; SUBRAMANIAN, U.; ANDERSON, W.P.; LÉAUTIER, F.A. Integration of transport and trade facilitation: selected regional case studies. Washington: The World Bank, 2001. 144p.

LIMA, S. Proximidade com vias de transporte deve formar pólo exportador. Jornal do Tocantins, Palmas, 25 jun. 2000. p.16.

LIMÃO, N.; VENABLES, A.J. Infrastructure, geographical disadvantage and transport costs. 2002. http://netec.wustl.edu/BibEc/data/Papers/ fthwobaco2257.html (10 Oct. 2002)

MORISUGI, H. Evaluation methodologies of transportation projects in Japan. Transport Policy, v.7, n.1, p.35-40, 2000. 
MORISUGI, H.; OHNO, E. Proposal of a benefit incidence matriz for urban development projects. Regional Science and Urban Economics, v.25, n.4, p.416-481, 1995.

NAKAMURA, $\mathrm{H}$. The economic evaluation of transport infrastructure: needs for internal comparisons. Transport Policy, v.7, n.1, p.3-6, 2000.

PEREIRA, J.C.R. Análise de dados qualitativos: estratégias metodológicas para as ciências da saúde, humanas e sociais. São Paulo: Editora da Universidade de São Paulo, 2001. 157p.

PIRES, J.C.L.; PICCININI, M.S. A regulação dos setores de infra-estrutura no Brasil. In: GIAMBIAGI, F.; MOREIRA, M.M. (Org.). A economia brasileira nos anos 90. Rio de Janeiro: BNDES, 1999. p.217-260.

PIZZOL, S.J.S. Comportamento dos cafeicultores perante o risco: uma análise de três sistemas de produção da região de Marília, SP. Piracicaba, 2002. 150p. Dissertação (M.S.) - Escola Superior de Agricultura "Luiz de Queiroz", Universidade de São Paulo.

SIMONSEN, M.H.; CYSNE, R.P. Macroeconomia. Rio de Janeiro: Ao Livro Técnico, 1989. 553p.

TOBIAS, M.S.G. Modelo de planejamento integrado da organização espacial, do desenvolvimento regional e dos transportes para uma região em expansão de fronteiras: o caso da região oeste do Pará. São Paulo, 1999. 237p. Tese (Doutorado) - Escola Politécnica, Universidade de São Paulo.

TOCANTINS. Secretaria de Estado do Planejamento e Meio Ambiente. Dados básicos sobre o transporte no Tocantins. 2002. http://www.to.gov.br/seplan (05 set. 2002) 
UNITED NATIONS (ONU). Road development and the environment: methodologies for minimizing enviromental damage. New York: United Nations, 1999. 82p.

WEISBROD, G.; GROVAK, M. Alternative methods for valuing economic benefits of transportation projects. 2001. http://www.edrgroup.com/ pages/pdf/Comparing Approaches.pdf (10 Oct. 2002)

WHARTON JÚNIOR, C.R. Infra-estrutura para o crescimento do setor agrícola. In: ARAÚJO, P.F.C.; SCHUH,G.E. Desenvolvimento da agricultura: análise de política econômica. São Paulo: Pioneira, 1975. p.247-277.

WORLD BANK. Roads and the environment: a handbook. Washington: The World Bank, 1997. 226p. (Technical paper, 376)

WORLD BANK. Vozes dos pobres: Brasil: relatório nacional. Washington: The World Bank, 2000. 113p. http://www.worldbank.org/poverty/voices /reports/national/brazil.pdf (29 abr. 2004)

WWF-BRASIL. Desenvolvimento e conservação do meio ambiente: pesquisa com ribeirinhos, extrativistas, colonos assentados e madeireiros na Amazônia. 2001. http://wwf.org.br/publicacoes/download/ pesquisa_amazonia03.pdf (29 abr. 2004) 


\section{APÊNDICE}


APÊNDICE - Questionário aplicado aos entrevistados

Este questionário destina-se a captar as percepções dos diferentes agentes econômicos públicos, privados e sociais, localizados nos principais municípios tocantinenses lindeiros à Hidrovia Tocantins-Araguaia. Essas informações são necessárias para a elaboração da tese de doutorado do Prof. Alivinio Almeida junto à Universidade de São Paulo (USP).

\section{IDENTIFICAÇÃO DO ENTREVISTADO}

\begin{tabular}{|l|l|}
\hline Nome: & Data: \\
\hline Endereço: & \\
\hline Atividade Profissional/Função Atual: & \\
Grau de Escolaridade: & \\
\hline
\end{tabular}

2. CONSIDERAÇÕES SOBRE OS SERVICOS PRESTADOS PELA HIDROVIA TOCANTINS-ARAGUAIA NO MUNICÍPIO

\begin{tabular}{|} 
Na sua opinião, o que é Hidrovia? \\
Qual o seu grau de conhecimento e informação sobre a Hidrovia Tocantins-Araguaia? \\
Grau (nota de zero a 10): \\
\hline Você sabe qual o estágio de implantação da Hidrovia Tocantins-Araguaia no seu \\
Município? \\
( )inicial ( )intermediário ( ) )final ( )não sabe
\end{tabular}




\begin{tabular}{|c|c|}
\hline \multicolumn{2}{|c|}{$\begin{array}{l}\text { Você sabe qual a estrutura operacional da Hi } \\
\text { disponível em seu Município? } \\
\text { ( )porto para embarque/desembarque } \\
\text { ( )equipamento para transbordo de carga } \\
\text { ( )depósito para armazenamento de carga } \\
\text { ( )não existe } \\
\text { ( )não sabe }\end{array}$} \\
\hline \multicolumn{2}{|c|}{$\begin{array}{l}\text { Qual o grau de importância dos principais serviços prestados pela Hidrovia Tocantins- } \\
\text { Araguaia para seu município? }\end{array}$} \\
\hline Serviço & $\begin{array}{l}\text { Grau de importância } \\
\text { (nota de zero a 10) }\end{array}$ \\
\hline $\begin{array}{l}\text { transporte de mercadorias } \\
\text { transporte de pessoas } \\
\text { transporte de animais } \\
\text { atividades de turismo } \\
\text { outra: }\end{array}$ & $\begin{array}{l}\text { Nota: } \\
\text { Nota:- } \\
\text { Nota:- } \\
\text { Nota: } \\
\text { Nota:- }\end{array}$ \\
\hline \multicolumn{2}{|c|}{$\begin{array}{ll}\text { Você já utilizou os serviços oferecidos pela Hidrovia Tocantins-Araguaia? } \\
\begin{array}{ll}\text { ( ) sim. Qual sua avaliação em termos de } \\
\text { facilidade de acesso/uso } & \text { Nota: } \\
\text { qualidade } & \text { Nota: } \\
\text { tempo de transporte } & \text { Nota: } \\
\text { preços cobrados } & \text { Nota: } \\
\text { ( ) não. Qual o motivo? } & \end{array}\end{array}$} \\
\hline
\end{tabular}


3. CONSIDERACOES SOBRE OS IMPACTOS ECONÔMICOS, SOCIAIS E AMBIENTAIS DA HIDROVIA TOCANTINS-ARAGUAIA NO MUNICIPIO

\begin{tabular}{|c|c|c|c|c|c|c|}
\hline \multirow{3}{*}{\multicolumn{2}{|c|}{ Indicador }} & \multicolumn{5}{|c|}{$\begin{array}{l}\text { Você acredita que a Hidrovia provocará mudanças nesse } \\
\text { indicador? }\end{array}$} \\
\hline & & \multicolumn{3}{|c|}{ Sim } & \multirow{2}{*}{ Não } & \multirow{2}{*}{$\begin{array}{l}\text { Não } \\
\text { sabe }\end{array}$} \\
\hline & & Aumento & $\begin{array}{l}\text { Diminui- } \\
\text { ção }\end{array}$ & $\begin{array}{c}\text { Intensidade } \\
\text { (Notas de } 0 \text { a 10) }\end{array}$ & & \\
\hline (1) & Agricultura no Município & $(）$ & $(\quad)$ & & $($ ) & $($ ) \\
\hline (2) & $\begin{array}{l}\text { Indústria e Comércio no } \\
\text { Município }\end{array}$ & () & $(）$ & & $($ ) & $(）$ \\
\hline (3) & Turismo no Município & ( ) & $($ ) & & $($ ) & $(\quad)$ \\
\hline (4) & $\begin{array}{l}\text { Emprego e renda no } \\
\text { Município }\end{array}$ & ( ) & $(）$ & & () & $(）$ \\
\hline (5) & $\begin{array}{l}\text { Valor das propriedades } \\
\text { ribeirinhas no Município }\end{array}$ & $($ ) & $(）$ & & $($ ) & $($ ) \\
\hline (6) & $\begin{array}{l}\text { Oportunidades de } \\
\text { negócios locais }\end{array}$ & ( ) & $(）$ & & $($ ) & $(）$ \\
\hline (7) & Arrecadação municipal & ( ) & $($ ) & & $($ ) & $(）$ \\
\hline (8) & $\begin{array}{l}\text { Gastos públicos } \\
\text { municipais }\end{array}$ & () & $(）$ & & $($ ) & $($ ) \\
\hline (9) & \begin{tabular}{|l|} 
Serviços públicos \\
estruturais feitos pelo \\
município
\end{tabular} & ( ) & $(）$ & & $($ ) & $(）$ \\
\hline (10) & $\begin{array}{l}\text { Serviços públicos } \\
\text { sociais feitos pelo } \\
\text { município }\end{array}$ & ( ) & $(）$ & & $($ ) & $(）$ \\
\hline (11) & \begin{tabular}{|l|} 
Integração entre \\
regiões/comunidades \\
locais ou exteriores
\end{tabular} & $($ ) & $(）$ & & $($ ) & $(）$ \\
\hline (12) & $\begin{array}{l}\text { Atividades/espaços } \\
\text { para lazer no município }\end{array}$ & $($ ) & $($ ) & & $($ ) & $(）$ \\
\hline (13) & $\begin{array}{l}\text { Variedade da fauna } \\
\text { local }\end{array}$ & ( ) & $(）$ & & $($ ) & $($ ) \\
\hline (14) & Variedade da flora local & ( ) & $($ ) & & $($ ) & $($ ( ) \\
\hline (15) & $\begin{array}{l}\text { Cheias e enchentes do } \\
\text { rio no município }\end{array}$ & () & $($ ) & & $($ ) & $($ ) \\
\hline (16) & $\begin{array}{l}\text { Qualidade da água do } \\
\text { rio no Município }\end{array}$ & ( ) & $($ ) & & $($ ) & $($ ) \\
\hline
\end{tabular}


4. CONSIDERAÇÕES SOBRE A PRESENCA DA HIDROVIA TOCANTINSARAGUAIA NOS PROJETOS DO SETOR DO ENTREVISTADO

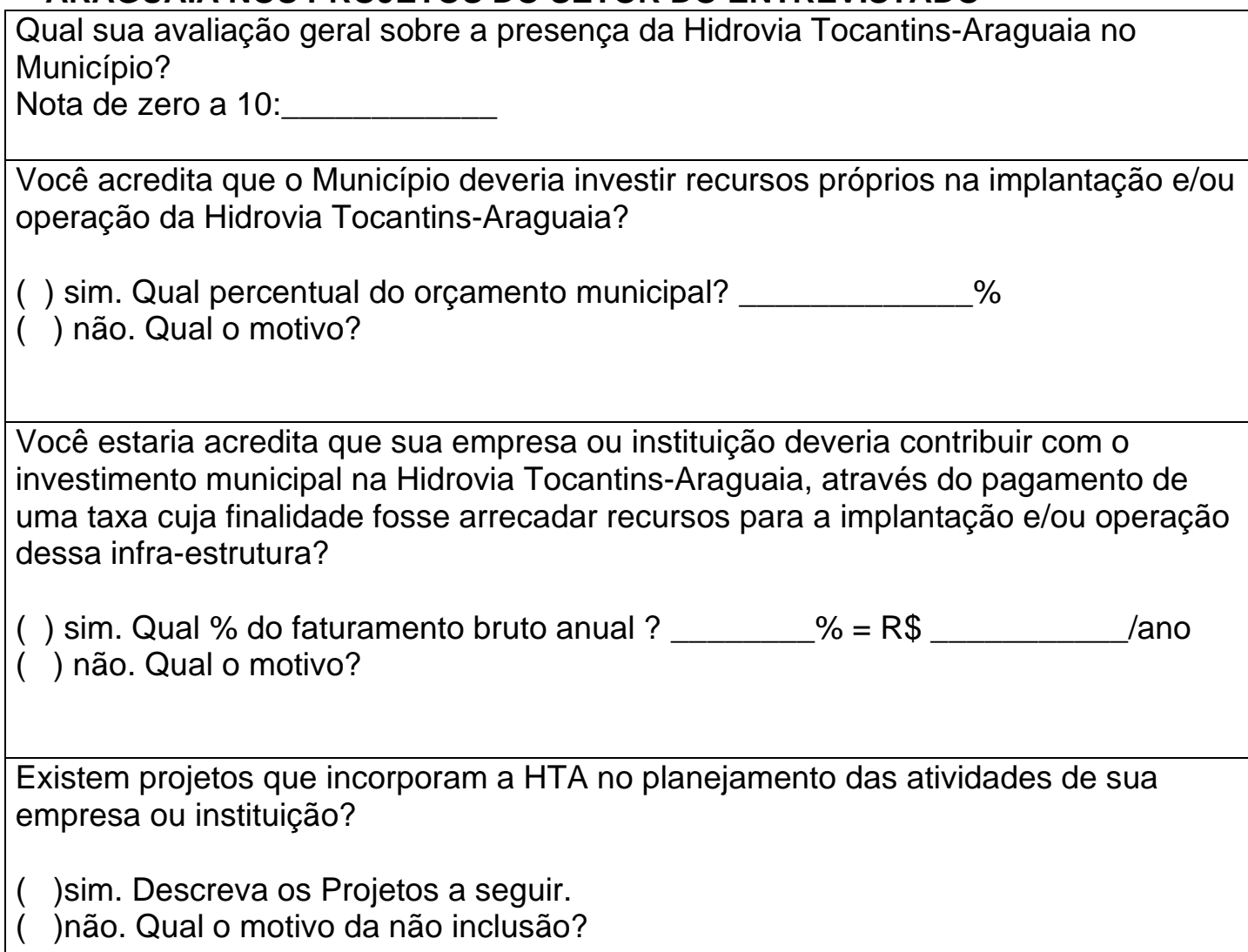

( ) sim. Qual percentual do orçamento municipal? $\%$

( ) não. Qual o motivo?

Você estaria acredita que sua empresa ou instituição deveria contribuir com o investimento municipal na Hidrovia Tocantins-Araguaia, através do pagamento de uma taxa cuja finalidade fosse arrecadar recursos para a implantação e/ou operação dessa infra-estrutura?

( ) sim. Qual \% do faturamento bruto anual ? $\%=\mathrm{R} \$$ lano

( ) não. Qual o motivo?

Existem projetos que incorporam a HTA no planejamento das atividades de sua empresa ou instituição?

)sim. Descreva os Projetos a seguir.

)não. Qual o motivo da não inclusão?

\section{Projeto 1}

.objetivo principal

.interação c/ HTA

Projeto 2

.objetivo principal

interação c/ HTA 